\title{
Urban Microcosms: Syngeneiai and the Sanctuary of Sinuri
}

Whereas Labraunda was gradually, and not without resistance, transformed from a dynastic and regional religious center into a polis sanctuary for Hellenistic Mylasa, the shrine of the Karian god Sinuri underwent a similar transition, but at a smaller scale. ${ }^{1}$ Sinuri was a local deity about whom we know very little, other than that his sanctuary was also embellished by the Hekatomnids and was the focus of a highly vocal syngeneia, or kinship group. Very different from the commanding heights of Labraunda, the sanctuary of Sinuri is located in a narrow valley surrounded by mountains, some 15 kilometers southeast of Mylasa (Figures 4.1-4.4). Despite the modest setting, this

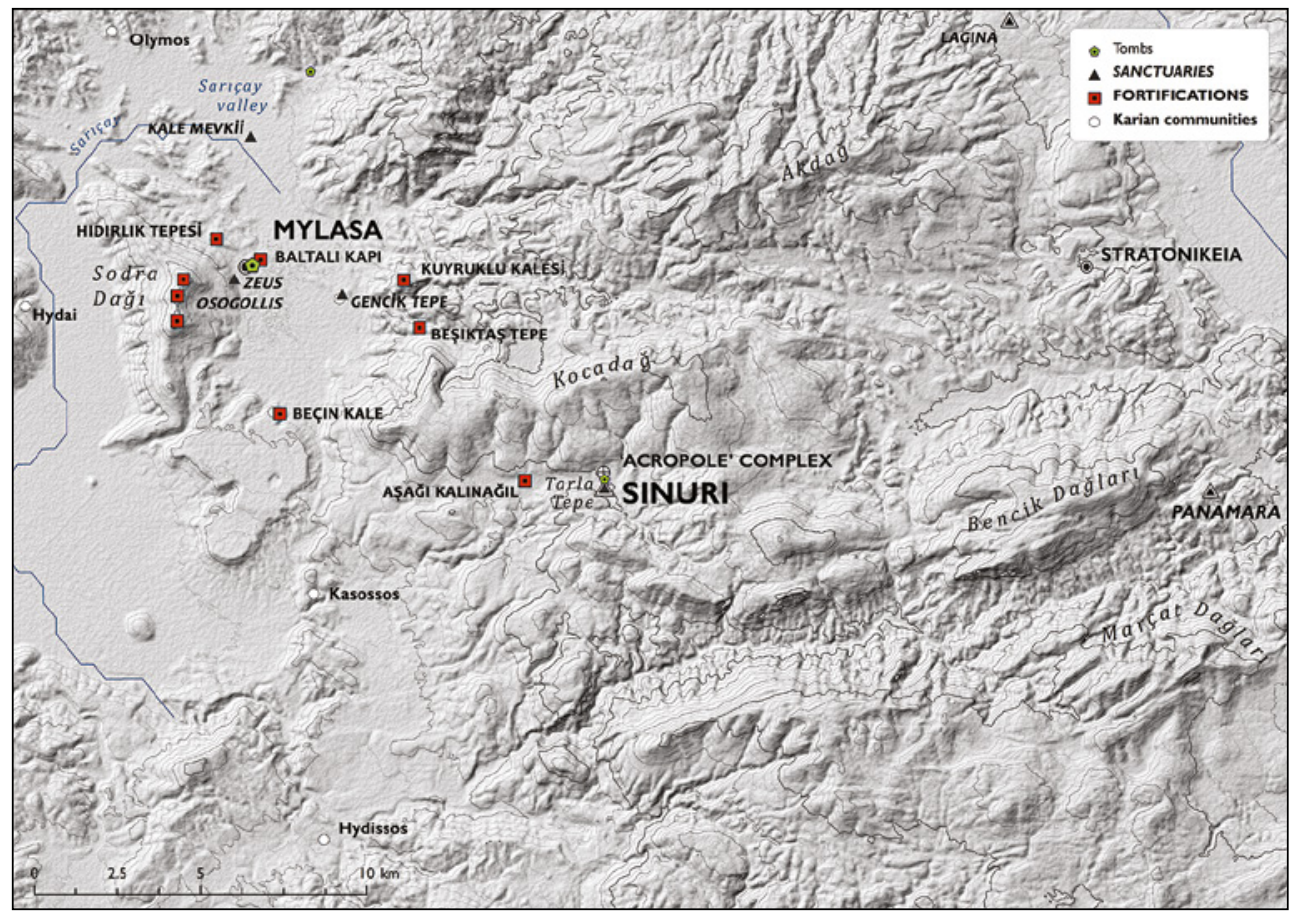

FIGURE 4.1 Map with the environment of the sanctuary of Sinuri

1 This section draws in part on Williamson (2016a).

(C) CHRISTINA G. WILliAMSON, 2021 | DOI:10.1163/9789004461277_005

This is an open access chapter distributed under the terms of the CC BY-NC. 4 . Pliccense. Williamson - 9789004461277 
shrine was a monumental religious center in the chora that came to mirror the function of urban sanctuaries with regard to its administration, economic position and defining impact upon its community.

The shrine of Sinuri had apparently always been oriented towards a syngeneia rather than the Mylasa as a whole. Syngeneiai were a base unit of Karian society and they typically revolved around a sanctuary, as was especially common in the area of Mylasa. The Pormounos syngeneia, which administered the sanctuary of Sinuri in the Hellenistic period, certainly defined itself according to the institutional model of polis and used the sanctuary as a public platform to regulate their economic affairs and honor individual members of their society. Although this was not strictly speaking an urban sanctuary, it was treated as one by this sub-community of the polis, for whom it played a crucial role in solidifying their identity.

Historical Overview of the Sanctuary of Sinuri

The first clear signs of religious activity at the site of the sanctuary date from the seventh century $\mathrm{BC}$, when it may even have acted as a place of refuge; the robust temenos wall from this period would have aided this function. ${ }^{2}$ Fragments of pottery in the Fikellura or Wild Goat style indicate some degree of regional connectivity in the sixth century вс. ${ }^{3}$

The fourth century ВС was a major period in the regional recognition of the sanctuary. This is when it was patronized by the Hekatomnids, putting it on a par with the two other Karian sanctuaries to receive the attention of the satraps - that of Zeus Labraundos and Artemis at Amyzon. ${ }^{4}$ Hekatomnos

2 Older finds at the site include two stone-axes from the Neolithic period and some Geometric pottery fragments, Devambez (1959), 9 and 24 for the remains from the Geometric and Archaic periods (also Taf. 22-26). Observing signs of intensive albeit sporadic occupation, Devambez suggests a refuge function in this early period.

3 Devambez (1959), 24 and Taf. 23; Cook (1992), 26o n. 36.

4 For Labraunda, see Chapter 3 above. At Amyzon, Idrieus dedicated a structure at the sanctuary of Artemis with an architrave inscription similar to those as at Labraunda, Robert and Robert (1983), no. 1; they believed this to belong to the propylon, but see now Hellström (2009), 276 and 288 who shows it to belong to the (Ionic) temple. Regarding Sinuri, Hornblower states that "the great period of the sanctuary is the fourth century; but the evidence for this is epigraphic not archaeological: the building remains from fourth-century Sinuri are disappointing compared with the effort and money spent at Labraunda ... Labraunda and Halikarnassos, the religious center and the secular capital, were to be the showpieces, and the dedications elsewhere are on a smaller scale altogether," (Hornblower (1982), 277-278). Devambez, however, dates the second phase of the temenos walls to the first part of the fourth century, 
personally dedicated an altar table and possibly a doorway, ${ }^{5}$ while the construction technique of the later temenos walls, and the characteristic use of platforms and terraces indicate his hand in the overall reconfiguration of the sanctuary. The shrine of Sinuri is situated near the edge of the plain south of Mylasa, not far from Kasossos and Hydissos (Figure 4.1), and its renewal by the Hekatomnids may well have been part of their overall consolidation of Karia, and perhaps the creation of a buffer zone around Mylasa, as Descat suggests. ${ }^{6}$ Ada and Idrieus, successors to Maussollos in the second part of the fourth century BC, were also involved with both the sanctuary and the syngeneia of Pelekos who administered it at that time, as they instructed them to admit a certain individual into their community, extending to him, and perhaps the syngeneia, the privilege of ateleia (tax exemption). ${ }^{7}$ The inscriptions at the sanctuary by the rulers were bilingual, in both Karian and Greek, indicating a strong indigenous element, more so than at Labraunda, where the Karian script is all but absent. ${ }^{8}$

Karian inscriptions, however, disappear by the early third century вС, when the sanctuary had apparently changed hands from the Pelekos syngeneia, who are no longer heard from, to the Pormounos syngeneia. Whereas the Pelekos syngeneia seems to have been largely autonomous, with direct connections to the rulers, it is apparent that in the course of the third century the syngeneia of Pormounos were under the auspices of the polis of Mylasa, as they used its calendar and magistrates to date their decrees. In this period they begin to acquire property for the sanctuary, joining in the hereditary lease practices that were typical for the area of Mylasa, particularly in the later Hellenistic period..$^{9}$ By the end of the third century, their holdings must have already been very significant, as they appear to have been pillaged by the troops of Antiochos III when they passed through the area. ${ }^{10}$ This act of violence also put the sanctuary on

Devambez (1959), 27-30, and the Hekatomnid signature is verified by Pedersen (1991), 103, who on further discusses the Hekatomnid expansion of the sanctuary of Artemis at Amyzon (p. 100-101).

$5 \quad$ I.Sinuri 76, discussed below. See also Debord (1999), 386, 403-404.

6 Descat (2013).

$7 \quad$ I.Sinuri 73 concerning Nesaios, discussed in more detail below. I.Sinuri 75 is heavily fragmented but also contains the word ateleia.

8 E.g. I.Sinuri 74 and 75, both now interpreted as part of the same inscription, based on the Karian text, see Adiego (200o). On the use of Greek and lack of Karian script at Labraunda, see Karlsson and Henry (2009), and the discussion on the scope of Labraunda in Chapter 3.

$9 \quad$ E.g. Chandezon (1998); Dignas (200o); discussed in more detail below.

10 Based on a fragment discussed by Robert in I.Sinuri p. 12, and reconstructed by Virgilio (2010), discussed in greater detail below. 
equal footing with the Artemis sanctuary in Amyzon, which underwent a similar fate, and that of Zeus Labraundos, which was spared by a protective letter from Antiochos III. ${ }^{11}$

Most of the inscriptions from the sanctuary of Sinuri date from the next two centuries, point to a second blossoming in the Hellenistic period as the syngeneia of Pormounos begin to profile itself as a highly efficient community, accumulating more and more domains for the god and administering the sanctuary in proper fashion. In this period the sanctuary and the festivals of Sinuri are clearly at the core of the identity of this thriving community, as their awards and decrees show.

By the later part of the first century the priesthood seems to have opened up to Mylasans in general - this may also signal the demise of the syngeneia since from this time there is little evidence of activity at any level, save for two remarkable monumental Roman tombs. The significance of the place, however, must have remained apparent as it was turned into a Christian center in the Byzantine era.

\subsection{Data and Sources}

Louis Robert visited the site on 29 October, 1934 and was able to identify it as the sanctuary of Sinuri based on an inscription which he saw there (I.Sinuri 2, Figure 4.16); his invaluable diary on the discovery, with a description of the journey and the landscape, has been published by Biagio Virgilio. ${ }^{12}$ After Robert returned to Istanbul, he proposed the excavation of the site to Albert Gabriel, founding director of the Institut Français d'Archéologique de Stamboul. ${ }^{13}$ The project was assigned to Pierre Devambez, later chief curator of Greek and Roman antiquities at the Louvre. Excavations took place the following year, from 24 August to 22 October, $1935 .{ }^{14}$ The ceramics were subsequently studied in 1937 by Emilie Haspels, of the University of Amsterdam. Publication plans were interrupted by the onset of war, yet in 1945 Louis Robert was able to publish the over 8o Greek inscriptions, which Devambez had assembled

11 Robert and Robert (1983), no. 18; I.Labraunda 46. The turmoil of this era is seen by some to correspond with the increase in asylia inscriptions at sanctuaries, discussed in Roels (2018a), 234-238 and esp. Mastrocinque (1984), Flashar (1999), and Knäpper (2018).

12 Robert (1935a), 335, also (1935b), 161-162 and I.Sinuri, p. 1. This was during his second trip to Karia in the fall of 1934 - his diary records his discovery of the inscription which convinced him of the identity of the site, later published as I.Sinuri 2, the dedication of an altar to the god by the tamiai and egdikoi. Biagio Virgilio studied Robert's notes which are now in the Fonds Louis Robert della Académie des Inscriptions et Belles-Lettres in Paris see Virgilio (2010), 59-64, republished in Virgilio (2011).

13 Now the Institut Français d'Études Anatoliennes (IFEA).

14 I.Sinuri, p. 1-4. 
and squeezed, in the volume Le Sanctuaire de Sinuri près de Mylasa. Première partie. Les inscriptions grecques. ${ }^{15}$ Fragmentary though they are, these documents make up the base for most of the insights into the changes that took place at this sanctuary and how it functioned; with some significant exceptions, the inscriptions primarily date from the second bloom of the sanctuary in the second and first centuries BC. ${ }^{16}$ The fourth century Karian inscriptions were published much later. ${ }^{17}$ Devambez and Haspels published the architecture and ceramics in 1959, in the second volume of Le Sanctuaire de Sinuri près de Mylasa. ${ }^{18}$ The meager amount of Hellenistic pottery appearing in the publications is in marked contrast with the number of inscriptions from the same period that laced the walls of the sanctuary. ${ }^{19}$ Yet the study of Hellenistic pottery is a growing field: with the knowledge now available, a new examination of the pottery from the sanctuary of Sinuri would no doubt revise several of the ideas presented here.

The quantity but also quality of sources at the sanctuary of Sinuri is much more limited than at Labraunda: the ceramics record is thus far below par, and the architecture inside the sanctuary was largely demolished in the Byzantine period, when many of the building elements were rearranged into a basilica, which, as Robert phrases it, "s'est implantée sur le sanctuaire et l'a digére."20 Nevertheless, a rough plan was discerned which forms the base for Figure 4.8, and for the chronological distinction of building phases. ${ }^{21}$

15 The I.Sinuri volume. The Karian inscriptions were originally planned to be published by E. Benveniste, but see now Ray (1990); Faucounau (1994); and Adiego (2000).

16 The honorific decrees, I.Sinuri 16-43, by the Pormounos syngeneia generally date from the second to first centuries BC; while some of the inscriptions documenting the land-lease transactions may date from the third century, I.Sinuri 11-15, most appear to date from the second century вС, I.Sinuri $45^{-72}$. Four inscriptions, I.Sinuri $73^{-76}$, date from the fourth century вC, while I.Sinuri $77-8$ o are from the Byzantine period. I.Sinuri 81 is a musical fragment that is only generally dated to antiquity. None of the inscriptions at the sanctuary date from the Roman imperial period.

17 Ray (1990); Blümel (1995); Adiego (200o).

18 Devambez (1959).

19 Devambez (1959), 31: "Nous voyons donc que sur la période qui s'étend du IV e siècle jusqu'aux temps romains inclusivement notre documentation est d'une extreme indigence. Ce sont les textees épigraphiques, et eux seuls, qui nous apportent des documents sur la vie du sanctuaire."

$20 \quad$ I.Sinuri p. 103.

21 Based on the map in Devambez (1959), 47 and clarified as to building phases in Pedersen (1991), 104, Fig. 104. Neither map shows the orientation of the complex; I was, however, able to approximate this using a compass and GPS coordinates taken in 2010 (see Figure 4.8). 


\section{Environment of the Sanctuary of Sinuri}

\subsection{Physical Environment}

The sanctuary of Sinuri is situated some 15 kilometers east-southeast of Mylasa, on a hilltop called Tarla Tepe near the modern village of Çamlıbelen (Yukarı Kalınağll) (Figures 4.1 and 4.2). The sanctuary is located on a gently sloping hillside, about $540 \mathrm{~m}$ ASL, in a valley between the Bozdağ near Beçin Kale to the west, and the Bencik Dağı to the east (the sanctuary of Zeus at Panamara is at the other end of this range). The sanctuary is on the lower southern foothills of the Kocadağ mountain, which at $1022 \mathrm{~m}$ separates the valley from the Mylasa-Stratonikeia valley to the north. The mountains surrounding the sanctuary to the north, east, and south continue to rise, defining the perimeters of the valley (Figure 4.1). While these mountains and hills are more densely forested with pine trees, the area around the sanctuary and to the west of it is terraced and several modest houses and farmsteads dot the hillsides, including one just below the sanctuary, whose inhabitant in 2011 could still recall the French expeditions.

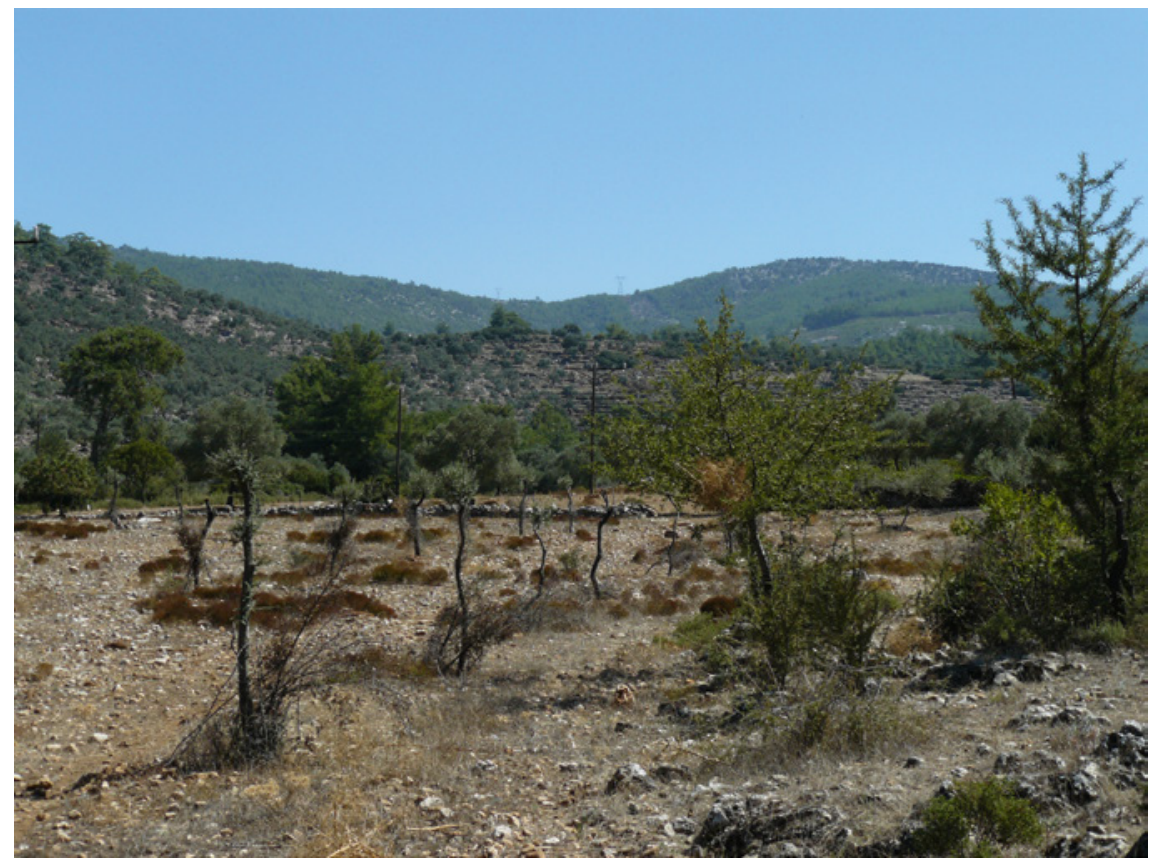

FIGURE 4.2 The sanctuary of Sinuri, on the Tarla Tepe hill in the center of the picture, seen from the west PHOTO AUTHOR 2010 
The dark red marble with white veins native to this area was used at the sanctuary, perhaps in the stoa (Figure 4.13), and is still being exploited today. Although the soil is stony, the valley is fertile and verdant in the springtime; terraces for crops and olive groves are predominant. Robert noted in 1934 that wood and charcoal were the mainstays for the villagers of Yukanı Kalınağıl (Çamlıbelen). ${ }^{22} \mathrm{He}$ also pointed out the strong contrast between the climates of the area of Mylasa and these hills which, with their higher altitude, receive more snow. ${ }^{23}$

Devambez, who excavated the sanctuary, saw no particular natural feature that might explain the choice of site. ${ }^{24}$ The fertility of the valley may also have been related to nature of the cult and the needs of the community that worshiped there, as many of the documents pertaining to land-lease contracts indicate. ${ }^{25}$ In fact, one of the inscriptions speaks of a sacred grove connected to the sanctuary. ${ }^{26}$ The sanctuary is at the threshold where the cultivated area meets the forested hills; perhaps this was the case in antiquity as well (Figure 4.2).

\subsection{Social-Geographical Location}

As Robert observed, the sanctuary of Sinuri is close to Kasossos (modern Ulaş), and nearly equidistant from the towns of Hydissos, Stratonikeia, and Mylasa, yet it was Mylasa that dominated this area throughout the Hellenistic period. Topography would have been a factor as the valley is best accessed from the west, i.e. the general direction of Mylasa. Also, Mylasa would have been concerned with its eastern territories and their integrity as the evolving boundary issues with neighboring Stratonikeia would imply. ${ }^{27}$

The sanctuary of Sinuri was always the center of a syngeneia, a community typically based on kinship ties. In the fourth century вс this was the Pelekos syngeneia, but by the Hellenistic period mention is made only of the Pormounos

22 According to his notes, published in Virgilio (2010), 61.

23 I.Sinuri p. 8-9, contrasting the general altitude of $400 \mathrm{~m}$ ASL of the valley with that of Mylasa, at c. 50 m ASL; it also snowed on the day of his visit on 29 October, 1934, Virgilio (2010), 61 .

24 Devambez (1959), 5: "Du sanctuaire au contraire, null échappé pour l'oeil, et comme il n'y a là ni source, ni grotte ni quelqu'un de ces accidents naturels autour desquels se cristallise souvent la piété des primitifs, nous ne pouvons deviner pour quelle raison ici s'est installé un culte assez important pour attirer vers ce cul-de-sac, des siècles durant, un foule de fidèles."

25 See below.

26 I.Sinuri 2.

27 I.Sinuri p. 29-31. Boundary disputes between Mylasa and Stratonikeia in the mid-second century вС are the concern of I.Mylasa 134, discussed in Ager (1996), no. 101. 
syngeneia, a community which clearly belonged to Mylasa. Whether this community lived near the sanctuary, in another location, or was more dispersed among the general population of Mylasa, however, is unknown. Roughly 500 $m$ north of the sanctuary and higher up on the hill is a second monumental but unexcavated complex with two large structures; Devambez designated this area as the 'acropole'. ${ }^{28}$ The structures here may have belonged to a settlement or an annex of the shrine; a path leading from the sanctuary below seems to run in this general direction, connecting the two monumentalized places, discussed below.

Although clear indications of an ancient road to the west have yet to be discovered, it likely will have followed the valley floor, like the modern asphalt road. Departing from Mylasa, this road first runs south, passing Beçin Kale (and the route to Halikarnassos) and bending east after western tip of the Bozdağ (Figure 4.1). This route appears to be confirmed by the presence of a tower (watchtower or fortified farm?) on a low hill a few hundred meters south of modern Aşağ Kalınağıl, and roughly 3 kilometers west of the shrine of Sinuri; the tower underscores the strategic or economic importance of this valley at least in the Late Classical or Hellenistic period. ${ }^{29}$ This structure would have been related to a road and probably to some economic or defense network in the valley. ${ }^{30}$ Robert found an area covered with ceramics near the village, and two marble fragments with traces of inscriptions. ${ }^{31}$ Beyond Çamlıbelen the valley grows steeper to the north or east and it seems unlikely, though not impossible, that there was any major thoroughfare in antiquity going in these directions. ${ }^{32}$

28 Devambez (1959), 33-34, the inscriptions are I.Sinuri 6 and $8 a-b$. This complex is discussed in more detail below, under Architecture.

29 Robert in I.Sinuri p. 7-8 describes a Hellenistic tower of red porphyry, $9 \times 11 \mathrm{~m}$ with walls 1 $\mathrm{m}$ thick; Akarca and Akarca (1954), 122; measured and drawn in 1997, Rumscheid (1999a)a, 175. Pimouguet-Pédarros (2000), 309-310 notes that the construction of this tower, 'Kassil Alik', is similar to that of the temenos of Sinuri; she interprets it as a watchtower and part of the Hekatomnid rural fortification system (ibid. 118-122, 124, and 317 n. 1312). Lohmann, however, believes it to be part of a farmstead because of its fertile setting and because he sees no reason to place a military watchtower at this location, Lohmann (2005), 43.

30 Pimouguet-Pédarros (2000), 124: “... la tour de Kassil Alik commandait la route de Mylasa à Sinuri." On the road network around Sinuri, Hild (2014), 44.

31 Robert in I.Sinuri, p. 7-8, I.Sinuri 1.

32 Hild (2014), 44 indicates that Sinuri was also accessible from Stratonikeia, but the terrain is prohibitive and there are few indications of contact that would suggest any major route of access from the east. 


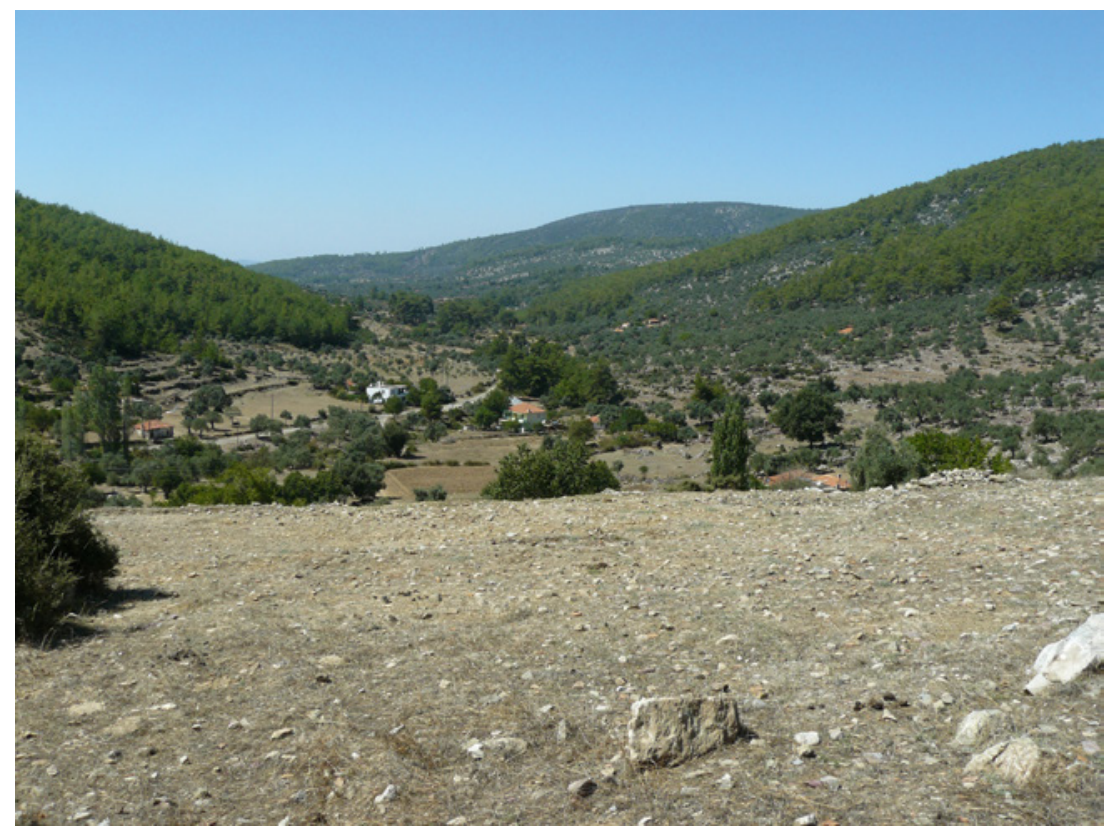

FIGURE 4.3 Sinuri. Extent of the view from the sanctuary to the west and the Bozdağ in the distance

PHOTO AUTHOR 2010

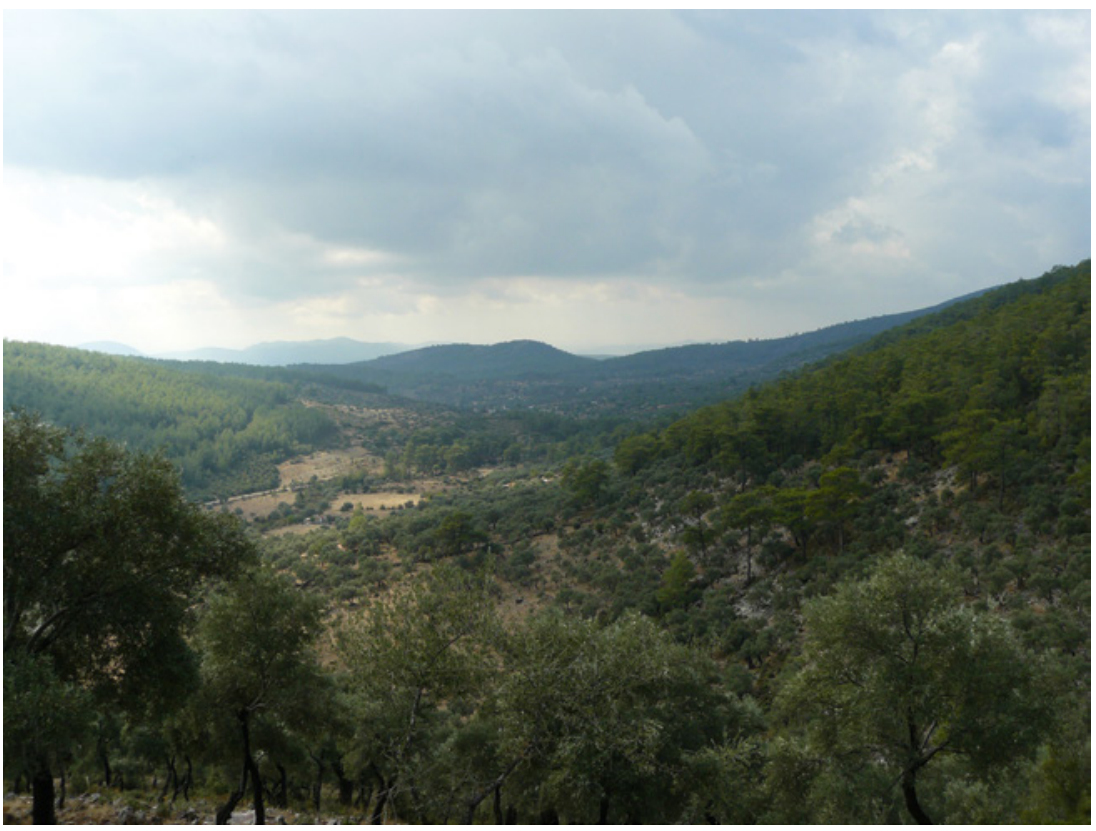

FIGURE 4.4 Sinuri. View from the northern 'acropole' complex looking west with the sea, the Myndos peninsula and the peaks of Kalymnos visible in the far distance PHOTO AUTHOR 2011 


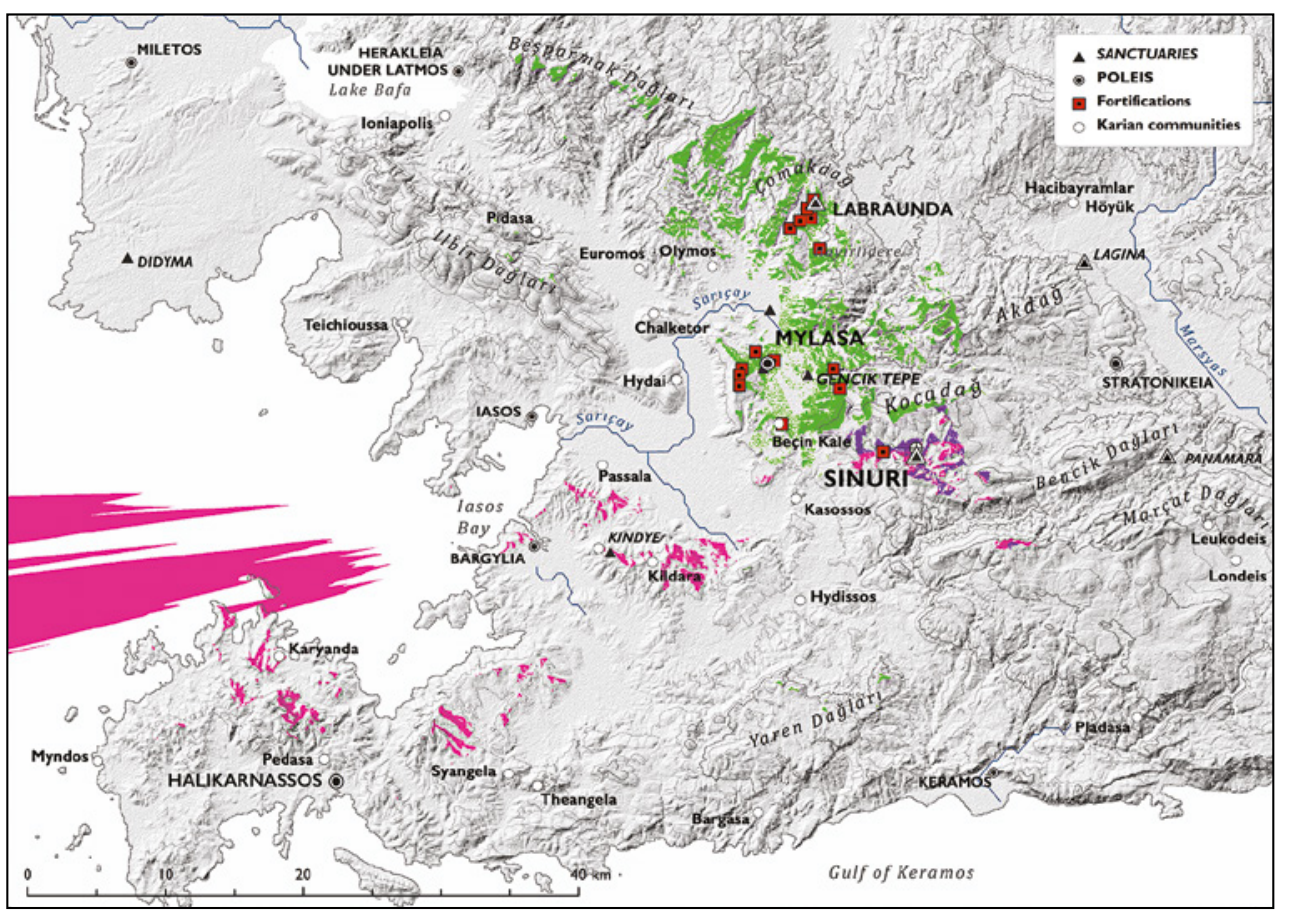

FIGURE 4.5 Viewsheds of Mylasa (green), the sanctuary of Sinuri (purple) and 'acropole' (fuchsia)

\subsection{Visibility}

The sanctuary is positioned towards the eastern and upper end of the valley, with a fair view down the valley to the west and the Bozdağ mountains southeast of Mylasa (Figure 4.3). The surrounding mountains to the north, east and south, however, obscure any view beyond and Devambez aptly describes the sanctuary as being in a 'cul de sac'. ${ }^{33}$ The structures higher up on the 'acropole' would have been visible, at least in part, although they are now entirely occluded by a forest. This area, roughly $15^{-20}$ minutes by foot to the north, offers a much better view to the west and the mountains of the Myndos peninsula near Halikarnassos, even the peaks of Kalymnos might visible on a clear day (Figure 4.4). ${ }^{34}$ The lower situation of the shrine, then, may well indicate a tight connection of the cult place with the valley. In any case, the view is entirely isolated from that of Mylasa (Figure 4.5).

33 Devambez (1959), 5, cited above.

34 Devambez (1959), 5-7. 


\section{Signs of Urban Integration at the Sanctuary of Sinuri}

The ways in which the relationship between the deity Sinuri and its community were expressed through the sanctuary in this narrow valley southeast of Mylasa are closely examined in this section, with an eye to the changes that took place in the Hellenistic period. Although the community involved was effectively a subdivision, rather than the entire polis, this is a prime example of how popular urban identity could be expressed through local shrines, and how these were conceptually modelled on the larger polis sanctuaries.

\subsection{Monumental and Ritual Space at the Sanctuary of Sinuri}

The sanctuary of Sinuri is quite a bit smaller than Labraunda and situated in a much more secluded area; nonetheless it was monumental and clearly built to impress, as the imposing robust walls make clear. The design, though partly obliterated by the construction activities of the Byzantine period, was still clear enough for Devambez to make a general plan of the layout in the different periods (Figure 4.6), showing a number of remarkable transformations which will be discussed in this part.

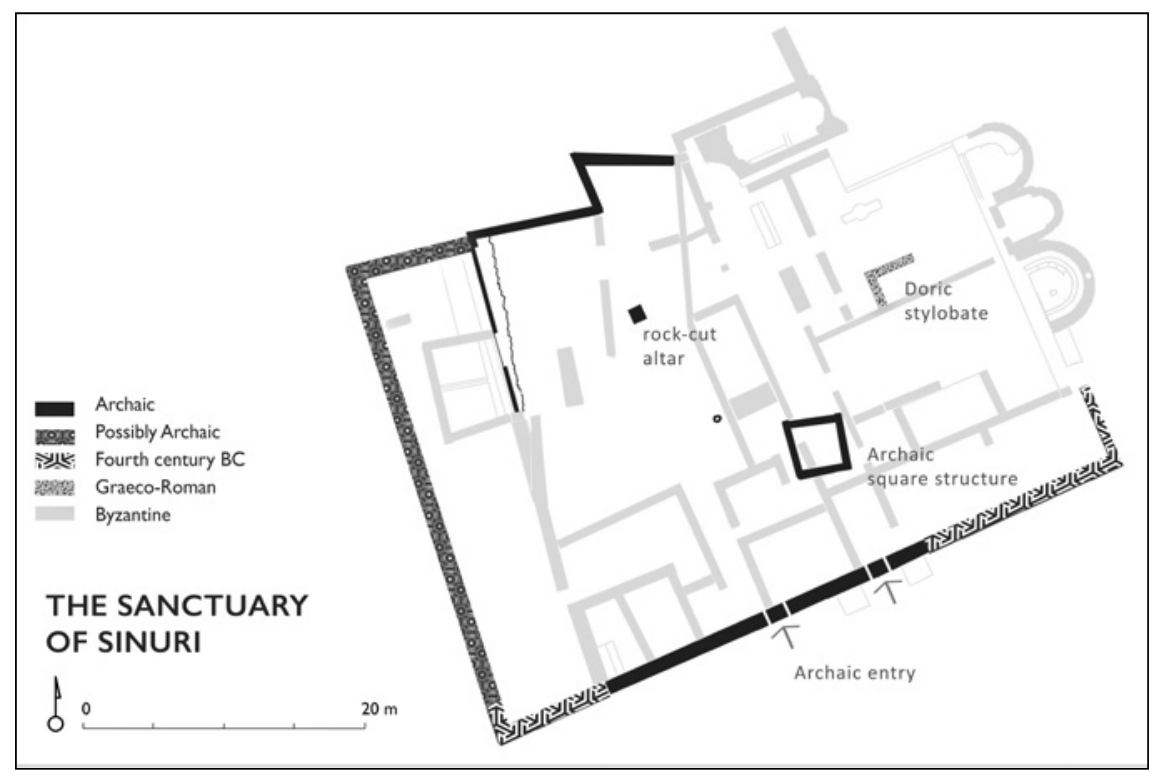

FIgURE 4.6 Plan of the sanctuary of Sinuri. After Devambez 1959, 47 and Pedersen 1991, 104 and Fig. 104; orientation assessed by author 


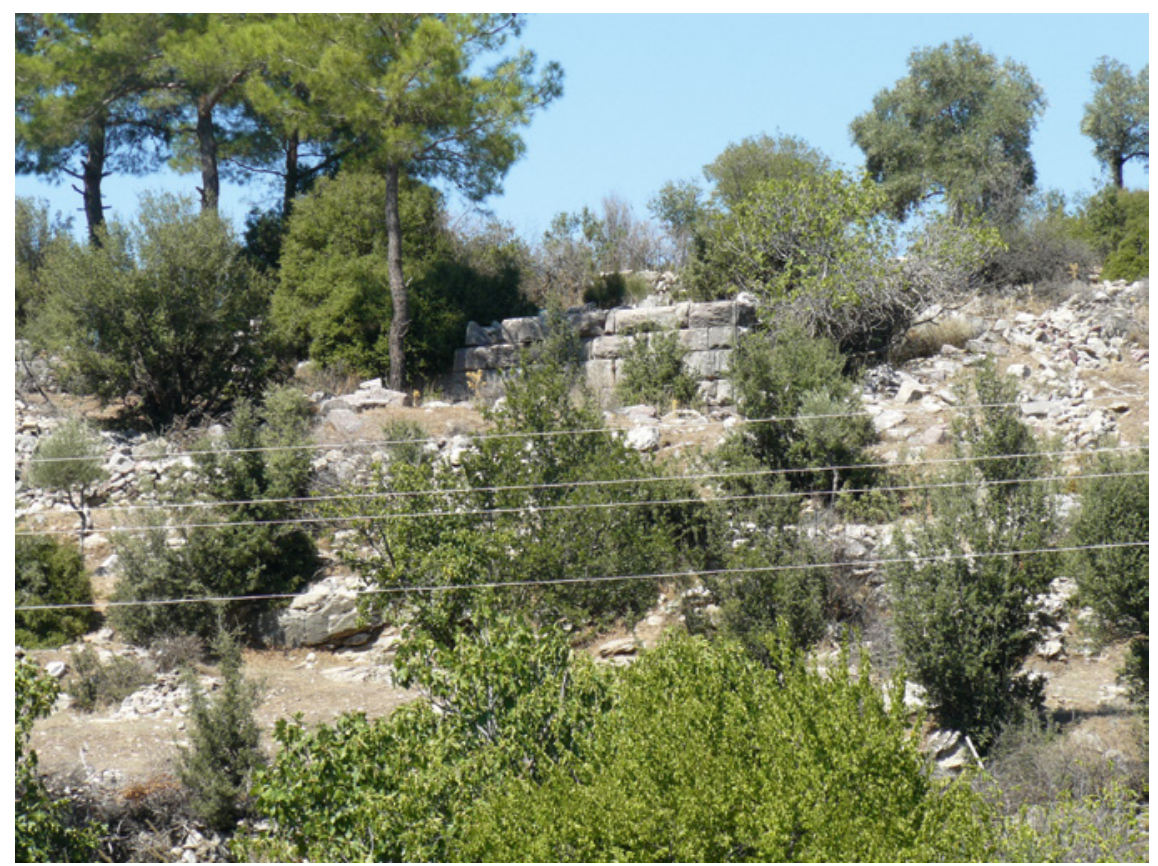

FIGURE 4.7 Sinuri. View of the sanctuary showing the southeast flank of the temenos wall, the drafted corner is visible PHOTO AUTHOR 2010

\subsubsection{Architecture}

The most prominent features are the temenos walls (Figures 4.7-9). Stretches of these are built of piled stone and date back to the Archaic period, when the first visible signs of a sacred place appear on this hilltop. ${ }^{35}$ Even in this period, the south(east) wall was the grandest, partly because it was on the lower side of the hill facing the valley, but also because of the robust construction technique (Figure 4.8). The entrance to the sanctuary in the Archaic period was located in this southern wall; Devambez considers this to be due in part to its relationship with the road from Mylasa, and the pilgrims arriving from there. ${ }^{36}$ Other structures interpreted as belonging to the Archaic period include the large rock-cut altar, a small square structure of unknown purposes, and a

35 Devambez (1959), 10-13 on the Archaic walls, $13^{-15}$ for the structures, and $23^{-25}$ for an overview of the Archaic period at the sanctuary.

36 Devambez (1959), 10 "Nous ne nous étonnerons pas que l'entrée du lieu saint ait été place ainsi vers le sud, c'est-à-dire du côte le plus proche du fond du ravin par où, sans doute, les fidèles venus de Mylasa se rendaient en pèlerinage." 


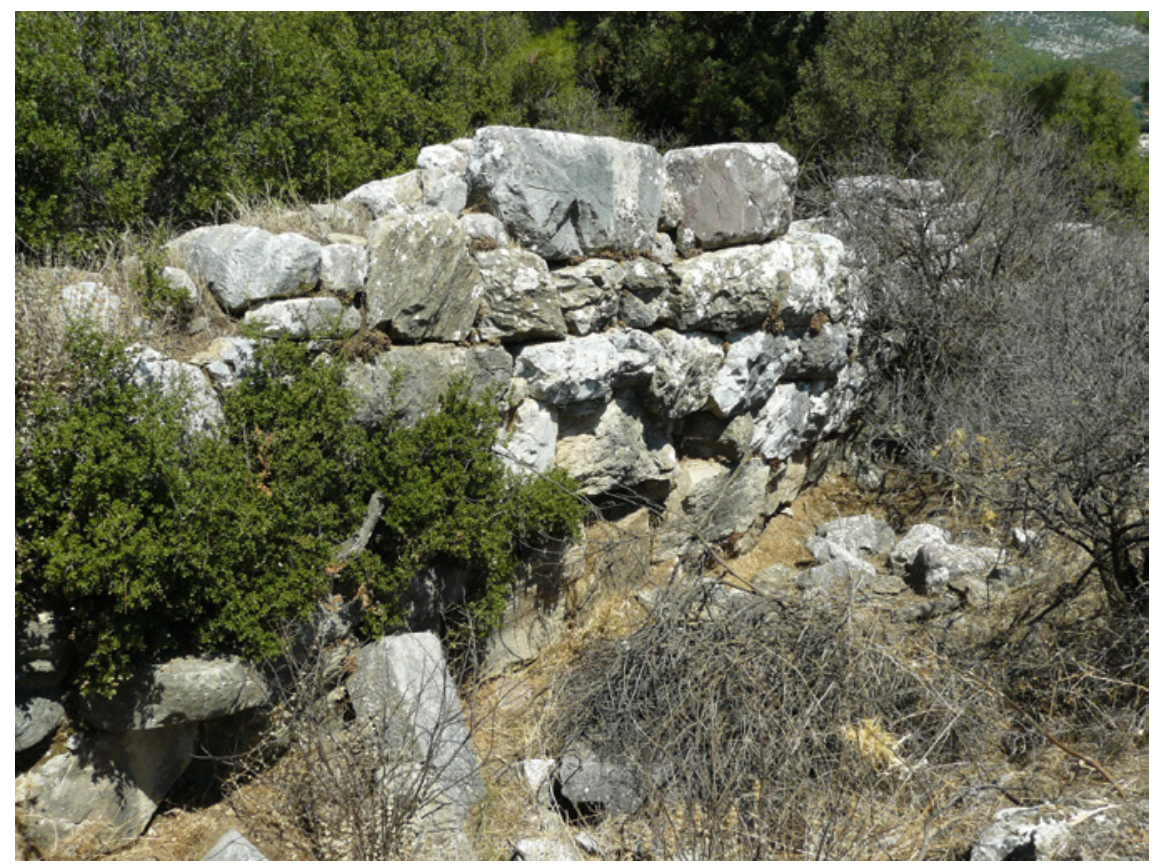

FIGURE 4.8 Sinuri. South section of the Archaic terrace/temenos wall PHOTO AUTHOR 2010

fossa, or dug-out storage area, where four large storage jars (pithoi) were found in situ. ${ }^{37}$

Like Labraunda and the sanctuary for Artemis at Amyzon, the sanctuary of Sinuri profited from royal Hekatomnid patronage in the first part of the fourth century. ${ }^{38}$ One inscription records their dedication of an altar table (trapeza) and probably a doorway (thyromata). ${ }^{39}$ The fine ashlar walls, still standing (Figure 4.9), date from this time as well, given the header and stretcher

37 Ceramics were found from the Late Geometric period on, with a peak in the late Archaic period, and a sharp decline after 5 оо вС, Devambez (1959), 9-25, 27. On the early period of the sanctuary, see Devambez (1959), 13-15; the pithoi are shown on Pl. IV, fig. 4 and Pl. XIV, figs. $2-3$.

38 Robert discusses Hekatomnid dedications at sanctuaries in general in I.Sinuri p. 102; see also Hornblower (1982), 274-293; Pedersen (1991), 100-107.

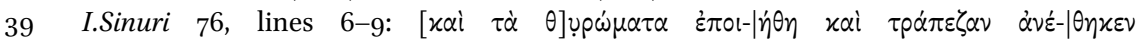

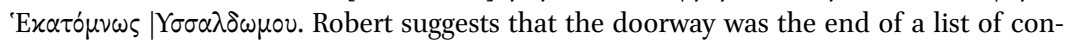
structions at the sanctuary by the syngeneia, while the altar table was specifically dedicated by Hekatomnos, hence the distinction in verbs, Robert in I.Sinuri, p. 99. 


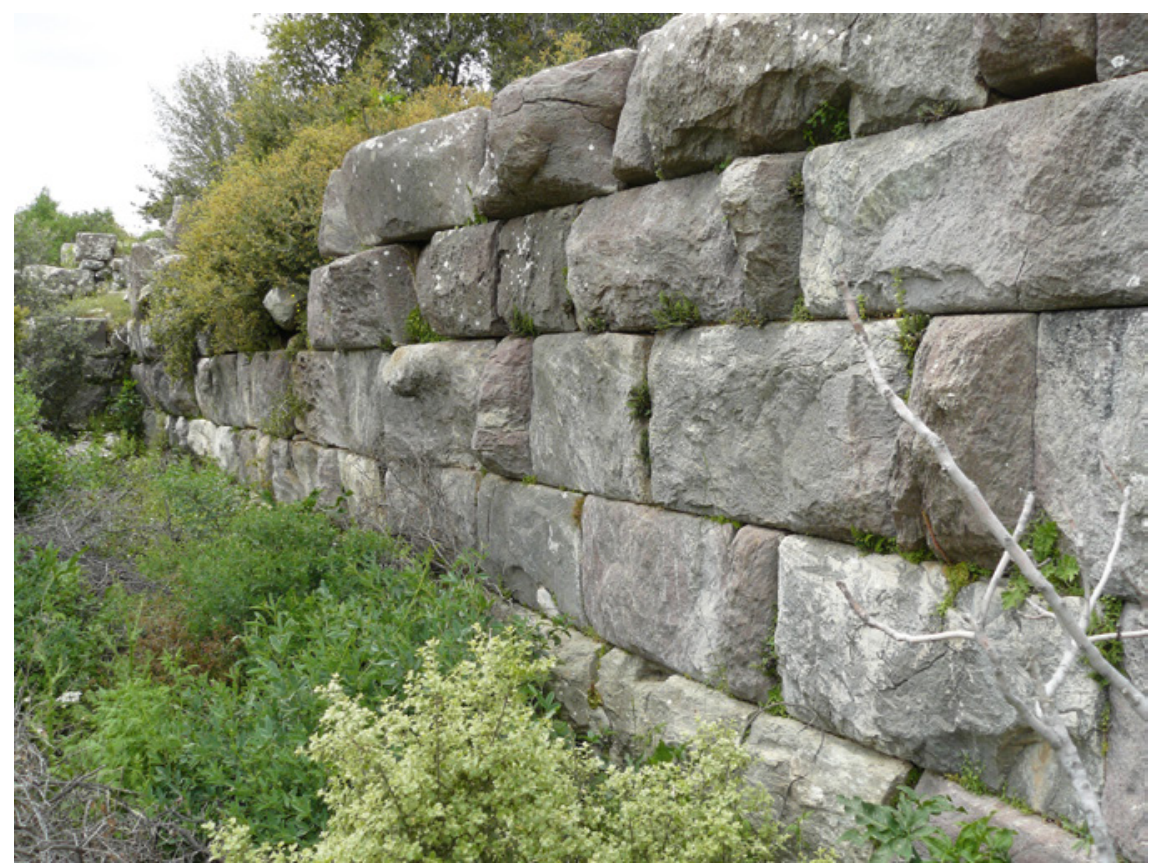

FIGURE 4.9 Southeast corner of the sanctuary with the fourth century temenos wall, showing the ashlar construction with headers and stretchers

PHOTO AUTHOR 2008

technique typical of Hekatomnid construction projects in the fourth century. ${ }^{40}$ The sanctuary was not only significantly expanded in this period to the east, but the southern temenos wall was also turned into a terrace wall: while the outer face consisted of regular ashlars, the inner face of this wall was made up of roughly piled stone, not meant to be seen; also, the Archaic southern entrance was blocked (Figures 4.10-4.11). Finally, the entire area was filled with earth. ${ }^{41}$

These modifications, together with the southwest corner of the temenos wall that underwent repairs in the same period, have been interpreted by Poul Pedersen as characteristic of the Hekatomnid 'modernization' of an old sanctuary, as at Labraunda, albeit on a much smaller scale. ${ }^{42}$ In his view, the trans-

40 Devambez dates the fine ashlar wall (Figure 4.10a-b) to the first part of the fourth century, Devambez (1959), 28-29. On Hekatomnid construction technique - here and at Labraunda, Halikarnassos, and Alinda, among many other places - see Pedersen (1991), 103-104.

41 Devambez (1959), 28-29.

42 Pedersen (1991), 103. 


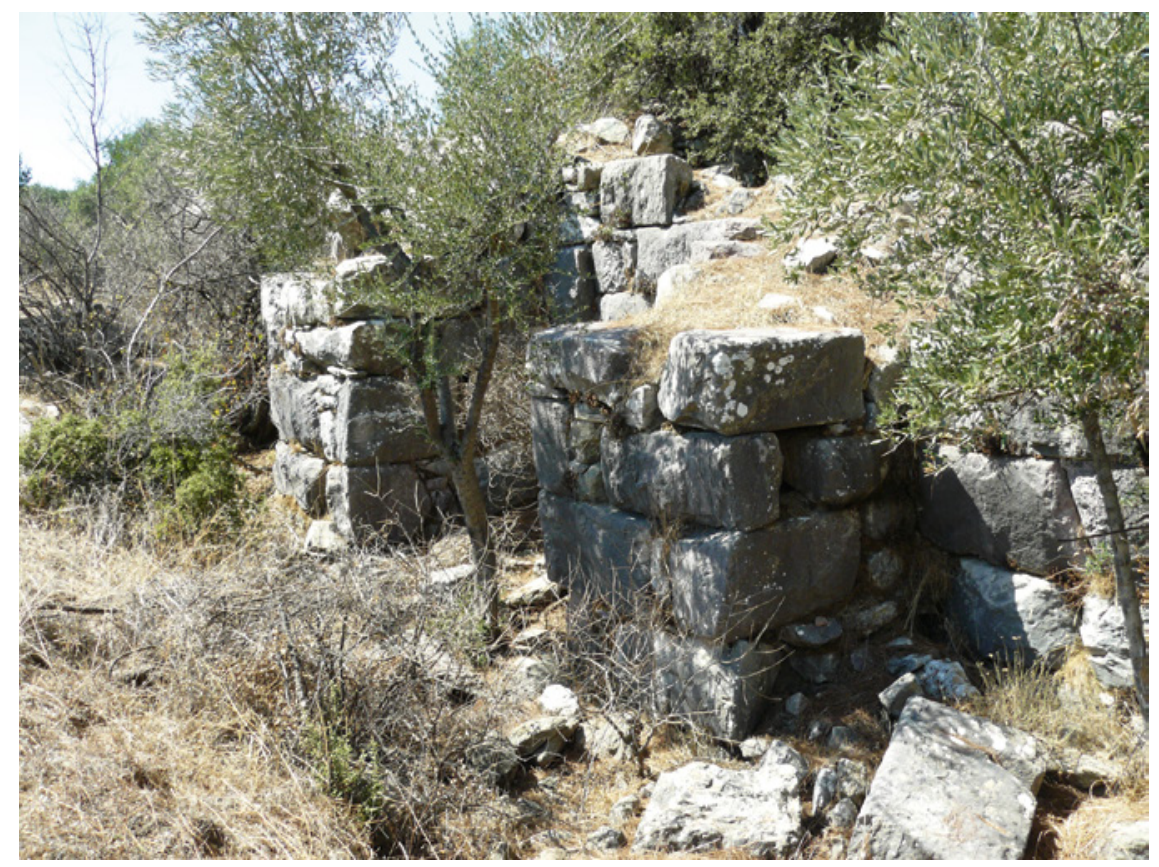

FIGURE 4.10 Sinuri. Archaic gateway with buttresses in the south wall PHOTO AUTHOR 2010

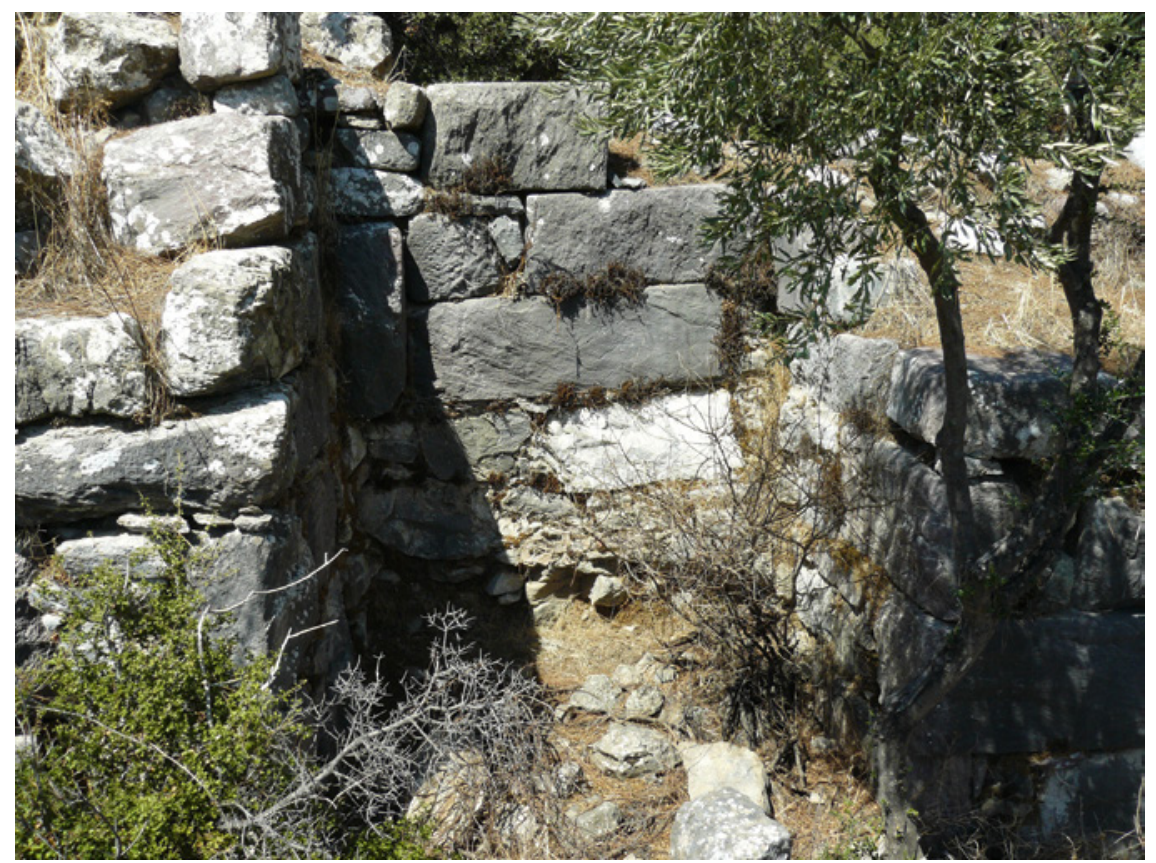

FIGURE 4.11 Sinuri. Archaic gateway with mid-fourth century blockage of the entry Pното AUTHOR 2010 
formation of the old Archaic sanctuary into a monumental platform perfectly coincides with the Hekatomnid approach, as the terraces not only expand the area for structures, but actually set them off. Like the lower retaining wall of Labraunda, the "long stretches of walling, often with rusticated, bossed ashlar work" shown in Figure 4.9 would have impressed and humbled the viewer upon approach. Moreover, the filtered access of staircases and staggered entries "were properties fitting to the buildings of gods and rulers, and in this sense the Karian terrace architecture could constitute the conceptual prototype for much Hellenistic architecture, not least the Pergamene."43

The Archaic structure was covered by the fourth century terrace, yet no evidence for a temple was found during the excavations. While this could support Carstens' suggestion that Sinuri had an open-air sanctuary, ${ }^{44}$ the fact that most of the eighty-plus inscriptions were cut into the surfaces of fine marble ashlars (rectangular architectural blocks), several of which were reused in the Byzantine structures along with other architectural pieces from the ancient sanctuary (Figure 4.12), points to some kind of monumental architecture. At least one of the inscriptions was cut in the local dark red marble (Figure 4.12-13), but many were in white marble, with a few in bluish-grey or black-and-white; these are not local and would have had to have been transported to the valley, perhaps from the quarries near Mylasa. In any event, they give us an idea of the bright and colorful contrasts in the use of building material, even though we do not know the exact location or function.

A good deal of the ashlars must have come from a stoa known to have been added to the sanctuary in the Hellenistic period. ${ }^{45}$ Figure 4.13 shows the striking block from the local red marble carrying the decision by the Pormounous syngeneia to construct a stoa, I.Sinuri 9. The direction of the text, across the narrow side of the block (shown here upside down), and the dowel hole in the short side indicate that this may have been part of a door jamb, perhaps from the stoa itself.

The Doric stylobate, discovered in the mid-eastern section of the sanctuary may have belonged to this stoa, although Pedersen considers a Hekatomnid

\footnotetext{
43 Pedersen (1991), 114-115.

44 Carstens (2009), 108-109.

45 I.Sinuri 9 (Figure 4.13b) and 1o both pertain to a decision by the Pormounos syngeneia to construct a stoa; Robert (I.Sinuri p. 28-29) relates this with I.Mylasa 502 , where a syngeneia appoints certain members to maintain the cult statue, part of the pronaos, and the altar of their sanctuary. On the stylobate, which once supported Doric columns, see Devambez (1959), 29-30.
} 


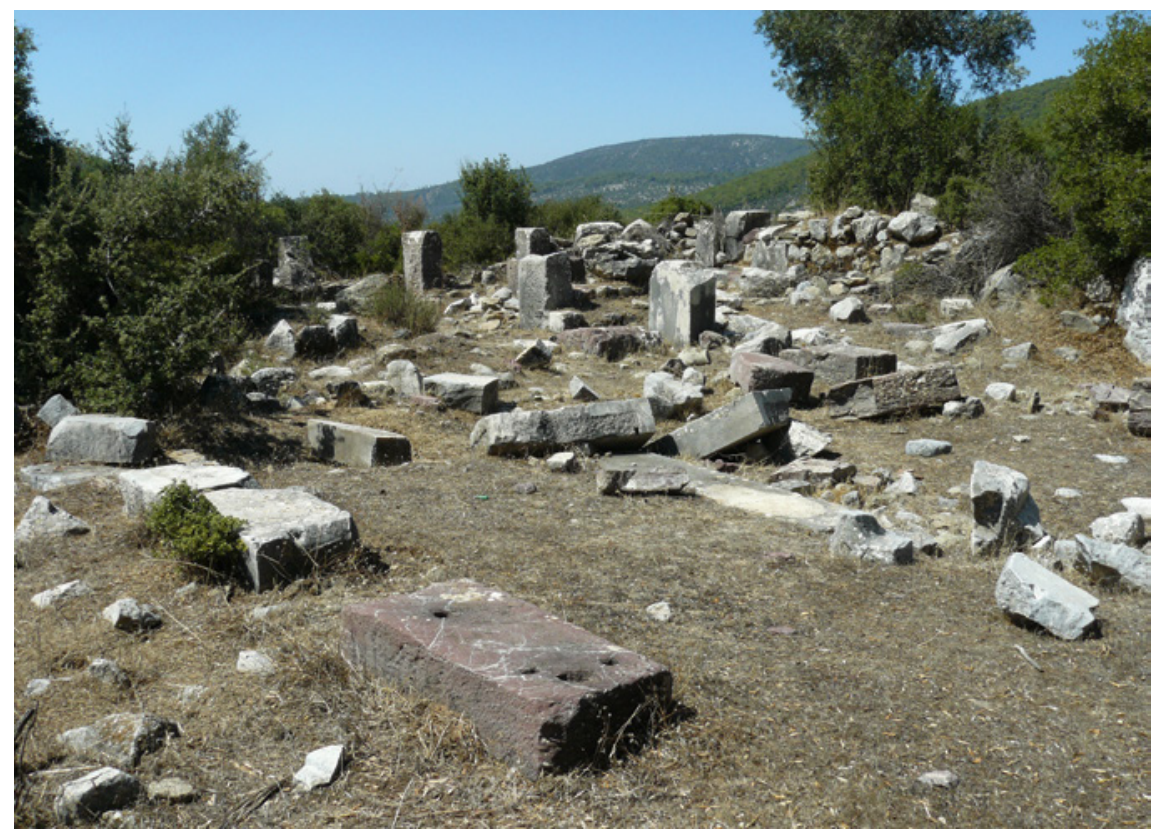

FIGURE 4.12 Sinuri. Central space of the sanctuary, view to the west. The Doric stylobate is in the middle right. The upright blocks belong to the Byzantine basilica PHOTO AUTHOR 2010

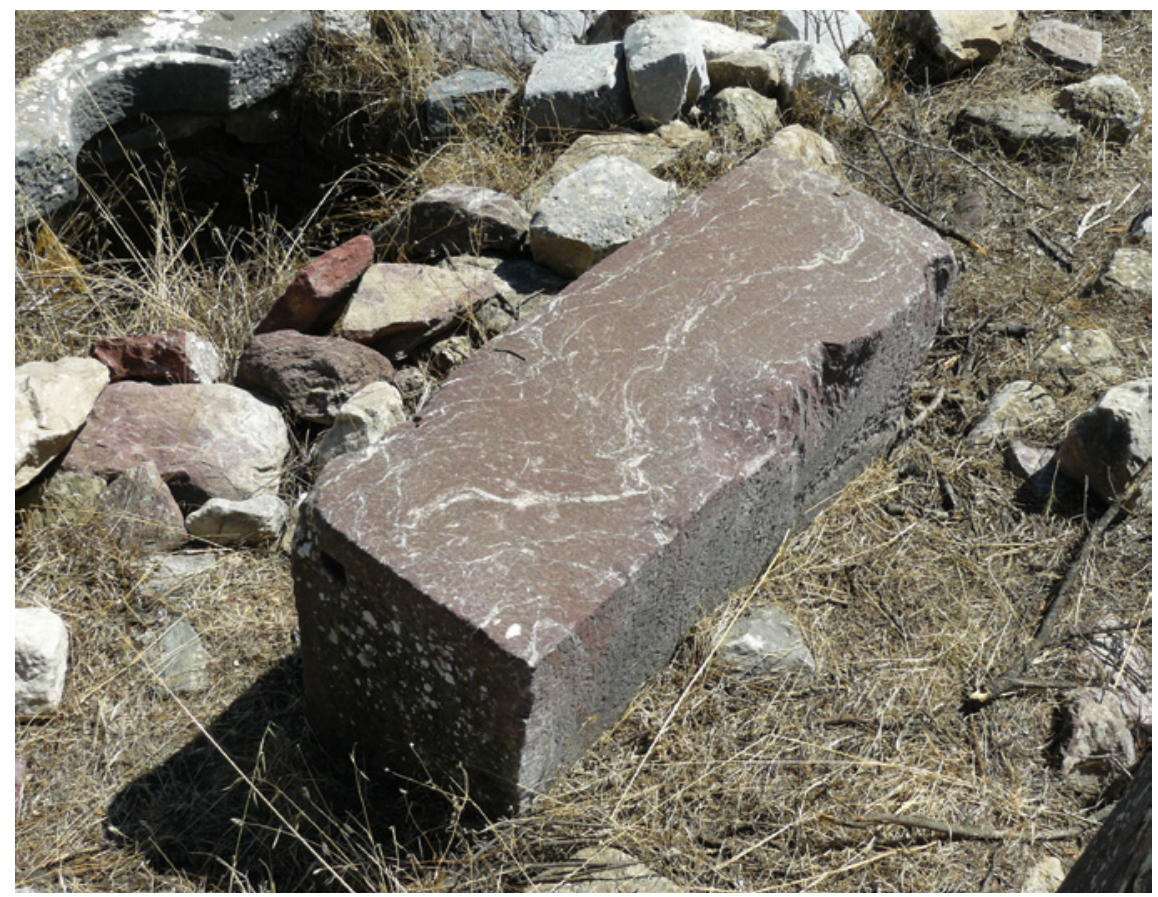

FIGURE 4.13 Sinuri. The eastern stoa. Red marble block, $118 \times 42.5 \times 67 \mathrm{~cm}$, carrying I.Sinuri 9 , honorific decree for Leon Iasonos et al. concerning the building of a stoa; the well is in the background 


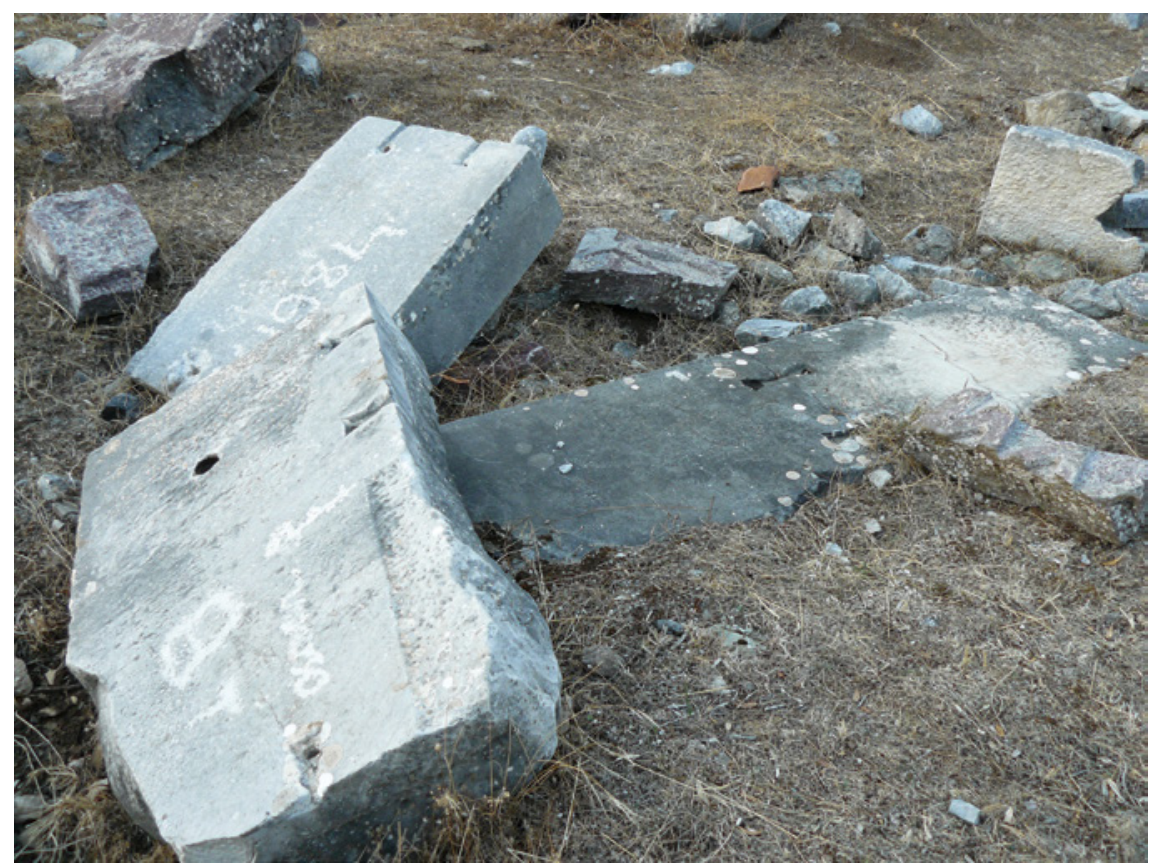

FIGURE 4.14 Sinuri. The eastern stoa. Section of the stylobate, with holes for dovetail clamps

PHOTO AUTHOR 2011

date based on the dovetail clamps (Figure 4.14). ${ }^{46}$ The trace of a column was found in the western corner indicates the southwest orientation of the structure, i.e. towards the interior of the sanctuary. Only the northwest corner of the stylobate was found, already indicating that it follows the same orientation as the south and east walls of the sanctuary (see plan, Figure 4.6). Given the narrow space between the stylobate and the eastern edge of the temenos, a stoa seems the most plausible interpretation for this structure.

One last feature that reflects the public nature of the temenos area is the bema, or step-like podium, on which some of the honorific decrees or

46 Devambez (1959), 29; Pedersen (1991), 103. If Pedersen is correct then the inscriptions would refer to a second stoa at the sanctuary, which would have been destroyed by the later construction activities. However I.Sinuri 10, discussed below, mentions the construction of a stoa in the east and that would seem to refer to this stylobate; I lean towards the interpretation of this stoa as the one referred to in the inscriptions, but making use of known techniques. 
monuments were to be erected. ${ }^{47}$ We cannot be certain as to where this was, although given the directional specifications for the location, 'on the left-hand as one enters ..., Robert suggests the gateway (pylon) in his restoration of the text. ${ }^{48}$

Roughly half a kilometer to the north of the sanctuary and fifty meters up the hill is a second monumental complex. Devambez designated this area as the 'acropole', where he discovered an embankment with retaining walls. ${ }^{49}$ He measured this terrace at some $5^{\circ} \mathrm{m}$ across, i.e. roughly as large as the surface area of the Archaic the sanctuary of Sinuri. Access was provided from the south by a ramp of c. $11.30 \times 3.60 \mathrm{~m}$. Devambez reported several marble blocks and two Doric capitals that he believed originated from this upper area. ${ }^{50} \mathrm{He}$ reported two structures on the terrace: an elongated building of $21 \times 6.50 \mathrm{~m}$, east-west, and opening to the south; and a second structure with two chambers some $20 \mathrm{~m}$ to the northwest, with an overall dimension of c. $12.75 \times 3.20 \mathrm{~m}$ and a similar alignment. Observing both the rough construction but also care given to certain details, e.g. the Doric capitals and moldings on certain pieces, Devambez remained in doubt as to the purpose of this complex, whether it had a 'rôle religieux' or were 'bâtiments civils'.51

Now heavily overgrown, these structures were 'rediscovered' by the author in 2011 (Figures 4.15-4.19). The embankments are constructed with large polygonal blocks with smoothed faces (Figure 4.15).

The southern tri-partite structure was constructed with rough ashlars on a foundation of irregular blocks, not unlike the shrine lower down. The chambers could each be entered through a central threshold, roughly two meters in width (Figure 4.16). The smaller building was found some forty meters to the northwest but was in much poorer condition, with walls of irregular doublefaced blocks. A crosswall could be distinguished (Figure 4.17), perhaps indicating two separate chambers or a chamber and a 'porch' area, not inconsistent with a small temple. ${ }^{52}$

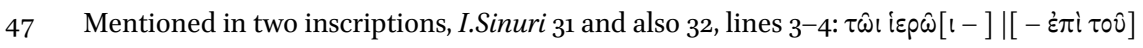
B.ं $\mu \alpha \tau[\circ \varsigma$.

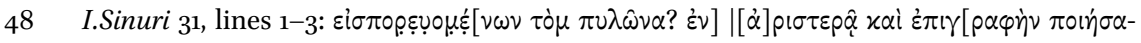

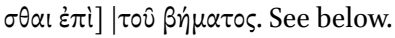

49 Devambez (1959), 33-34. Rediscovered by the author in October 2011; the heavy undergrowth and density of pine trees prevented accurate GPS recordings or verification of Devambez' measurements.

5 O Devambez (1959), 34 .

51 Devambez (1959), 34 .

$5^{2}$ Robert had suggested the possible presence of a temple on this hill, I.Sinuri, p. 20-22; see also Akarca and Akarca (1954), 122-123. 


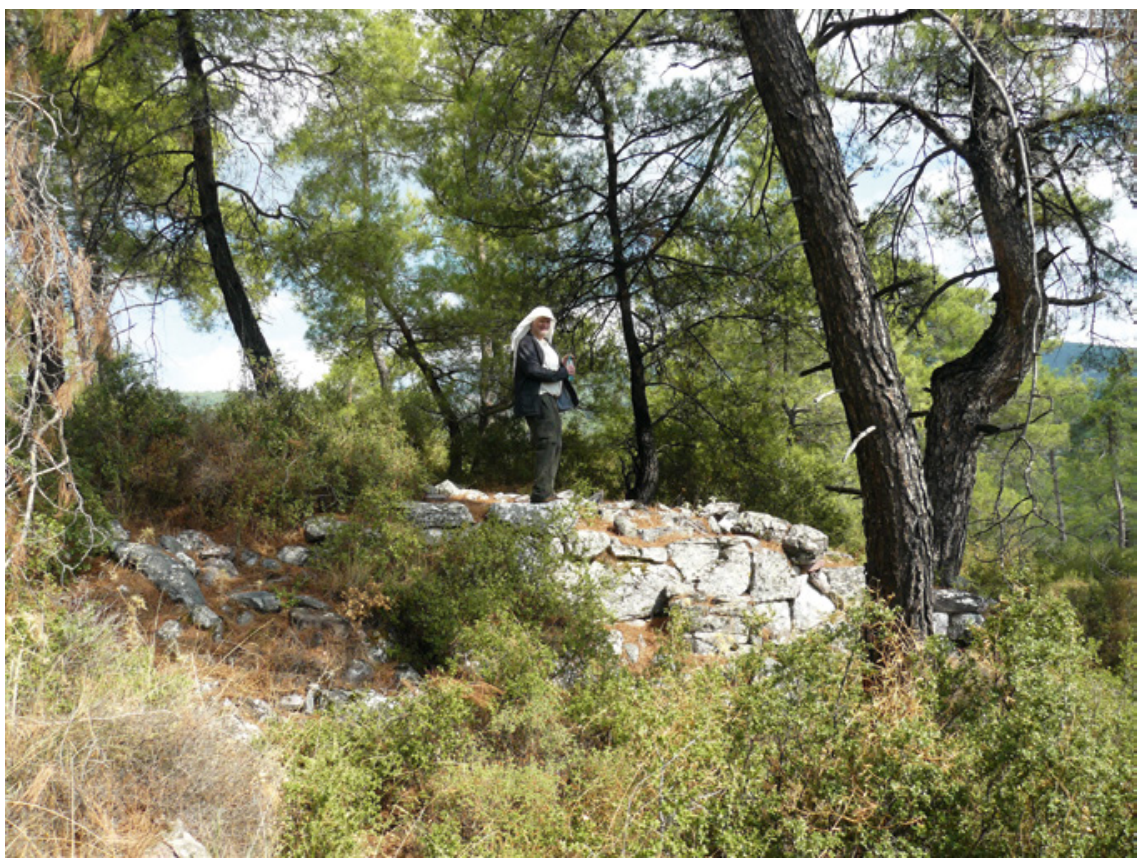

FIGURE 4.15 The 'acropole' complex, c. 450 m north of the sanctuary of Sinuri. Terrace structure. Southwest corner, with polygonal wall PHOTO AUTHOR 2011

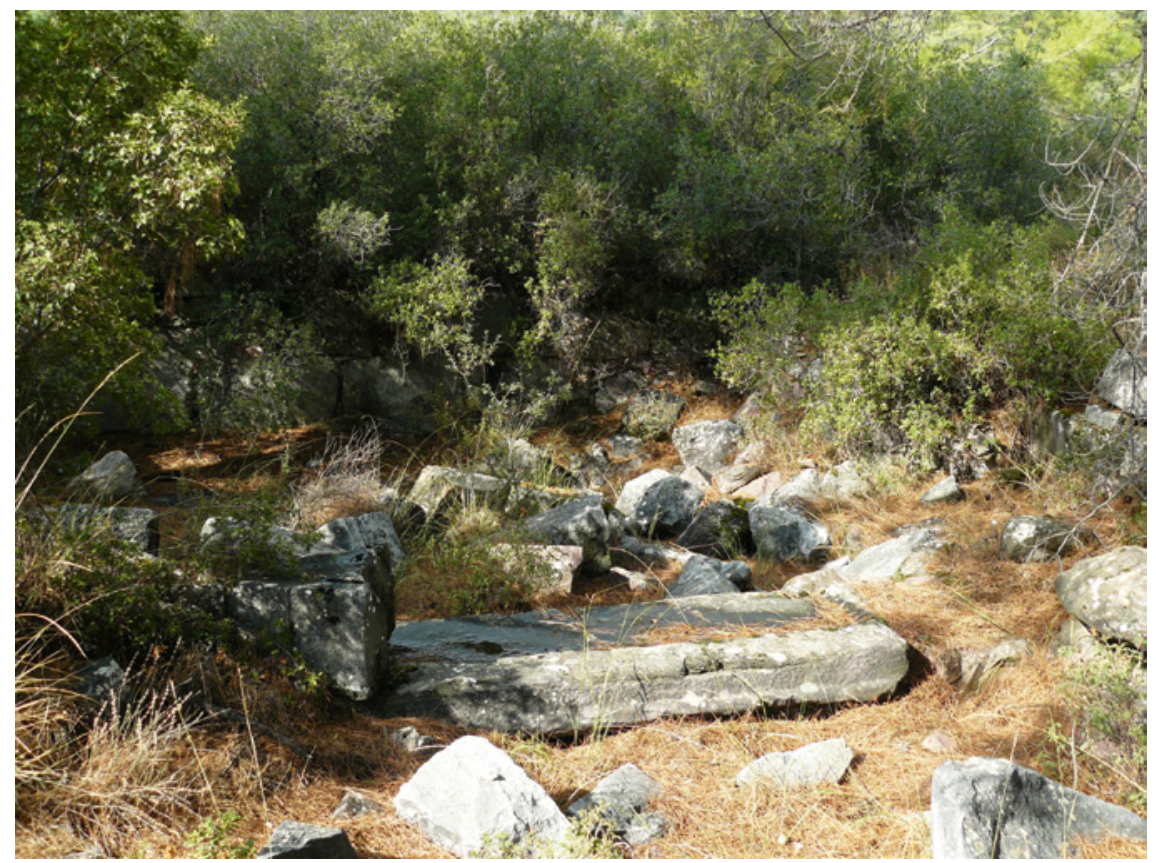

FIGURE 4.16 The 'acropole' complex. Square chamber with threshold in the southern wall Pното AUTHOR 2011 


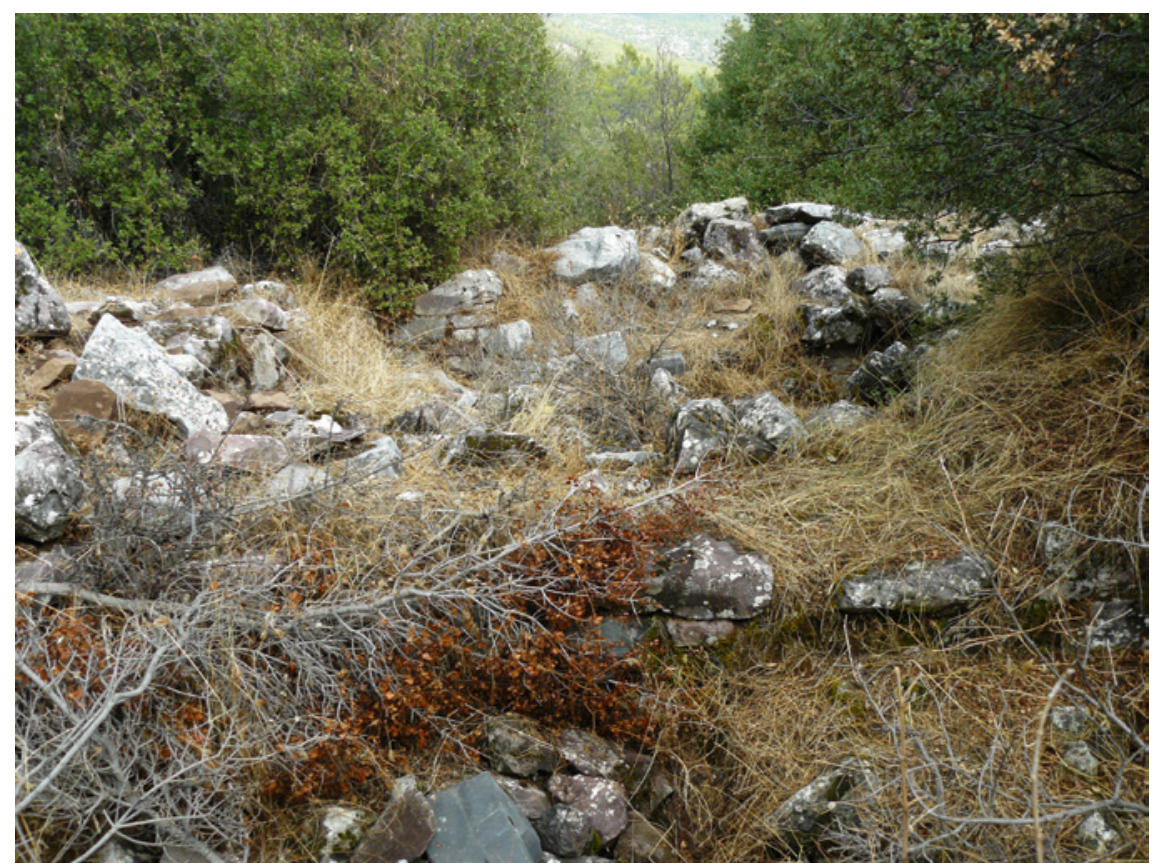

FIGURE 4.17 The 'acropole' complex. Smaller bi-chambered structure north of the terraced structure. Facing east. In the middle is the crosswall separating the two areas PHOTO AUTHOR 2011

More walls, loose ashlars, and cisterns may be found immediately to the south (Figure 4.18). Devambez did not discuss this area in any detail, yet the structures must have been coeval with the sanctuary and the two priestly dedicatory inscriptions found here clearly indicate a cultic connection. ${ }^{53}$ The stoa-like appearance of the multi-chambered structures suggests an auxiliary function, perhaps used during festivals, or as residence of the priests, or possibly connected to some settlement activity, although high concentrations of ceramics (especially storage vessels and rooftiles) seen along the terraces to the south indicate intensive use (Figures 4.19). The rock-cut tomb found roughly midway between the sanctuary and this complex could correspond with this, as well as the rock-cut feature closer to the shrine (Figures 4.20 and 4.21).

The 'acropole' complex occupies a prominent place on the hilltop overlooking the sanctuary and enjoyed a much more extensive view of the valley and the mountains beyond towards the west (Figure 4.4). Whether we should

53 Devambez (1959), 33-34. The inscriptions are I.Sinuri 6 and $8 \mathrm{a}-\mathrm{b}$, dedications by Hiereus and by his grandson Menippos, both listed as priests of Sinuri on I.Sinuri 5 . 


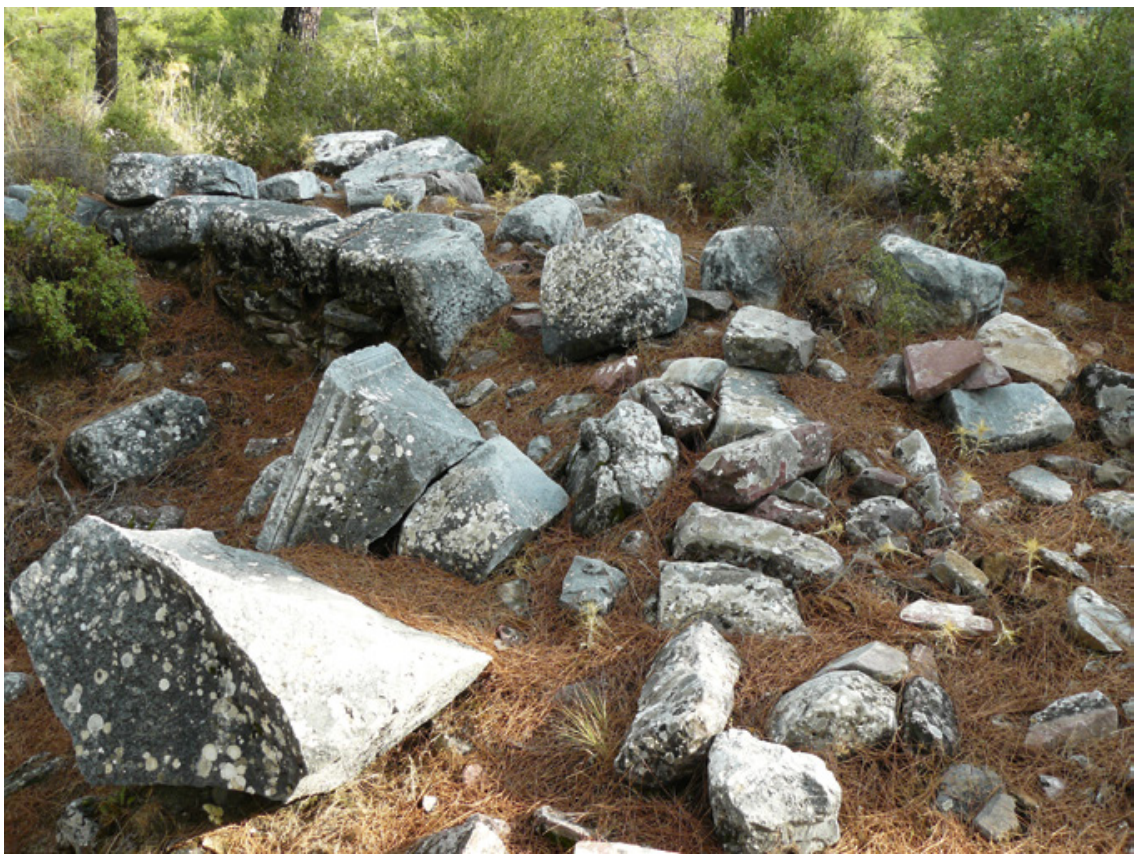

FIGURE 4.18 The 'acropole' complex. Walls and profiled blocks PHOTO AUTHOR 2011

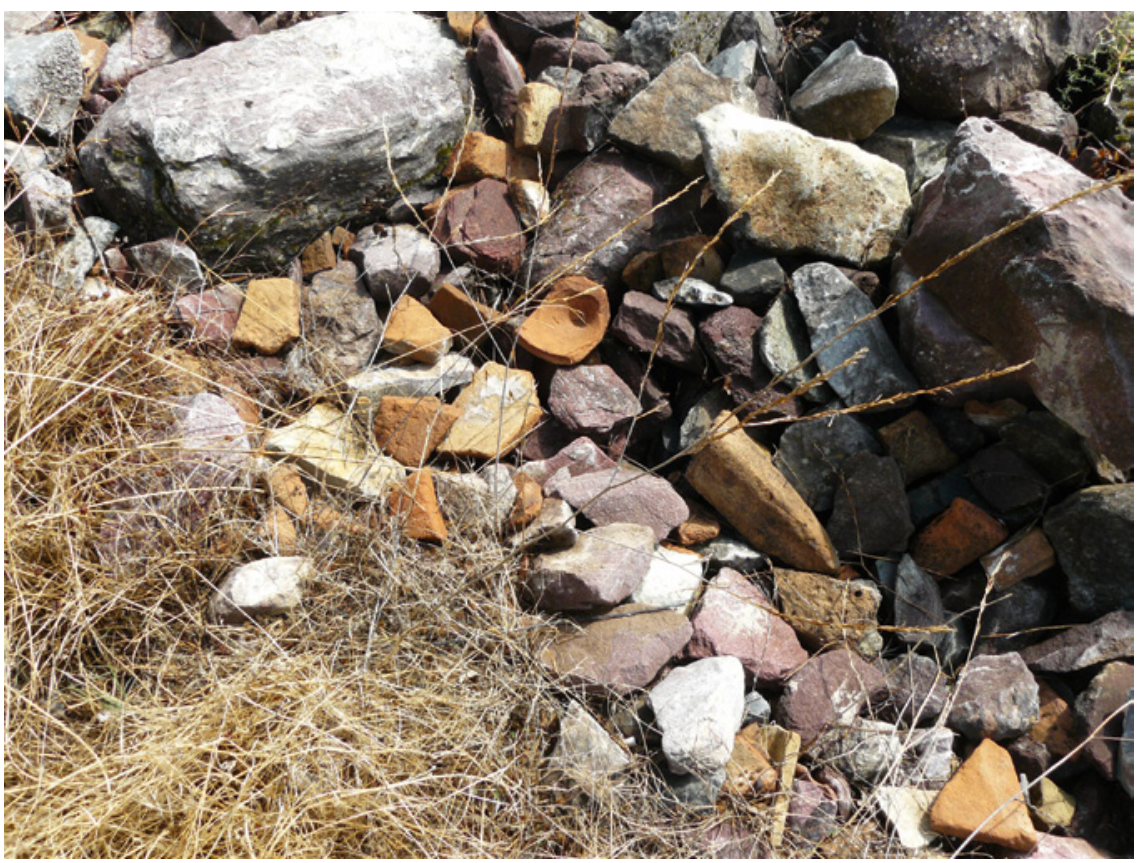

FIGURE 4.19 Ceramic concentration in terrace wall near the 'acropole'

PHOTO AUTHOR 2011 


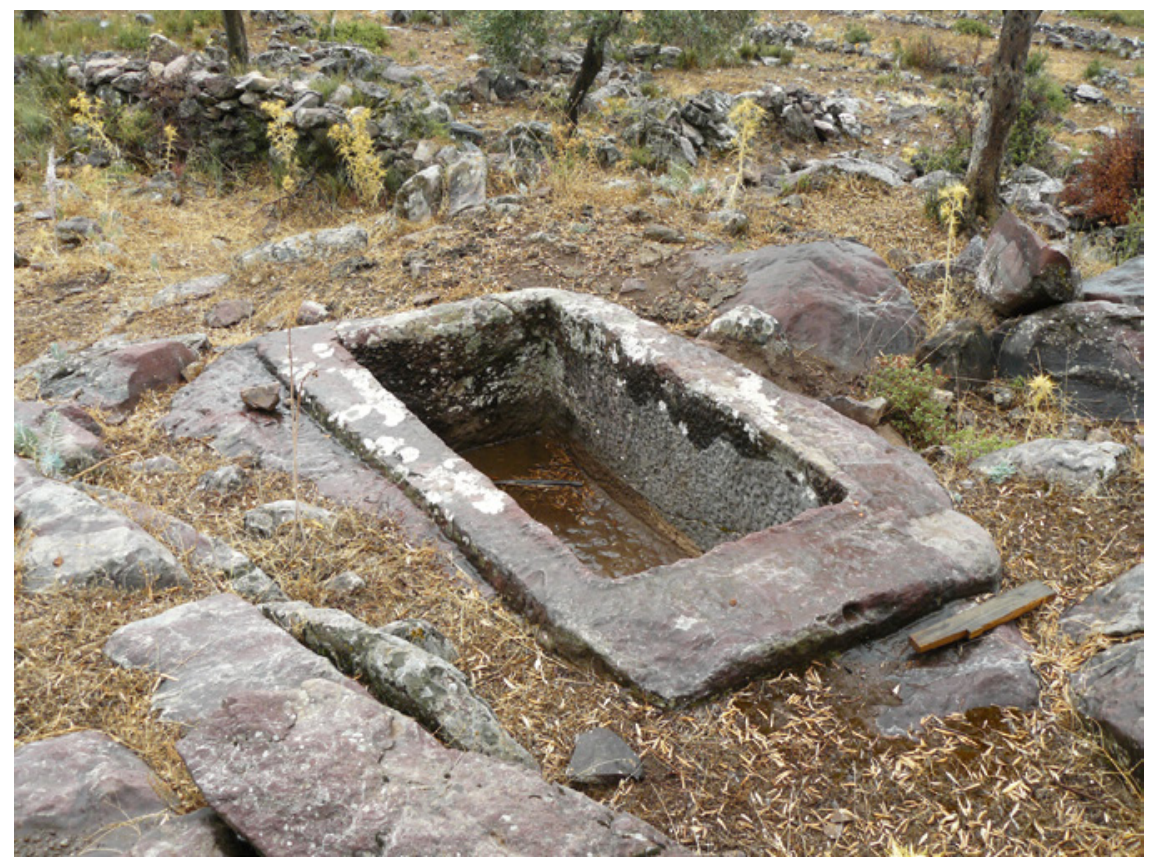

FIGURE 4.20 Rock-cut tomb c. 250 m north of the sanctuary of Sinuri PHOTO AUTHOR 2011

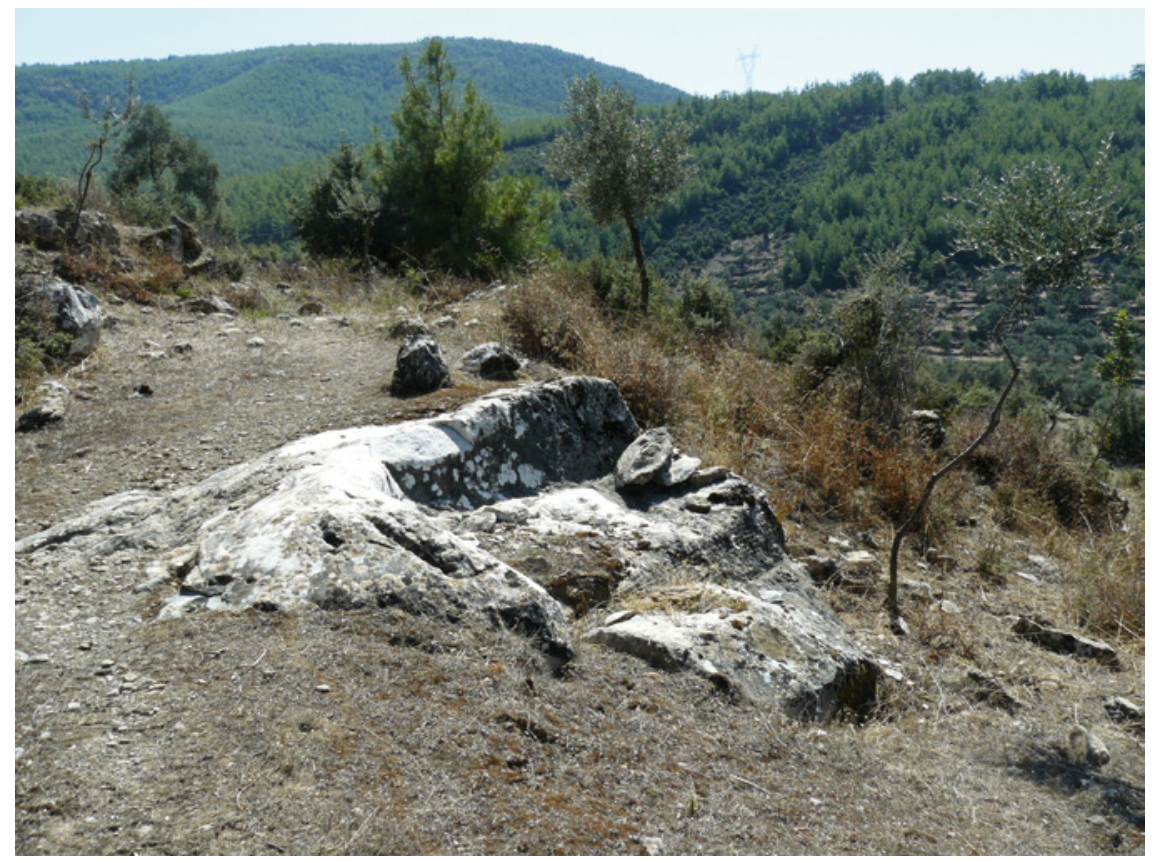

FIGURE 4.21 Rock-cut feature c. $110 \mathrm{~m}$ north of the sanctuary of Sinuri PHOTO AUTHOR 2010 
interpret this as some kind of permanent settlement, perhaps the political base for the syngeneiai, or whether it was mostly connected with the sanctuary during the festival must await further investigation, but the remains point towards a vibrant community at the sanctuary that took great pride in itself, with activities that extended well beyond the temenos of the shrine.

\subsubsection{Public Space - Concentric and Linear}

At about $30 \times 60 \mathrm{~m}$, the enclosed space of the sanctuary proper in the Late Classical and Hellenistic periods, though modest in comparison with Labraunda, was nonetheless impressive for such a seemingly remote site. ${ }^{54}$ The Doric 'stoa', or other structure that belonged to the stylobate, would have enclosed the temenos on its eastern side, drawing emphasis to the opposite area south of the altar as a space where a sizeable crowd could gather. Although less articulated than at Labraunda, this focused area would also have functioned as 'concentric space' for ritual activities to be performed and observed. ${ }^{55}$

Linear space is more difficult to discern at the sanctuary of Sinuri, with so little architectural or even landscape features to go by. Still it seems clear that the 'stoa', besides providing a backdrop, would also have created a kind of northeast-southwest axis across the sanctuary. This would have directed the view towards the west and southwest, the area south of the altar, and perhaps even towards the western access road from Mylasa. The excavator had observed that the Archaic building and the altar were both oriented towards the west (i.e. west-southwest). ${ }^{56}$ In fact, this coincides with the only 'panorama' that the valley has; the hills surrounding the sanctuary on the north, east, and south sides provide a natural telescopic view to the west, with the gentle crest of the Bozdağ at the far end (Figures 4.3-4.5).

Despite the sparsity of secure architecture at this sanctuary, several inscriptions actually tell us where the critical spots in the sanctuary were, even though they were not found in situ. Many of the honorific inscriptions explicitly state where they were supposed to be set up: next to the entrance. ${ }^{57}$ The entrance will likely have been part of the same complex with the doors (thyromata) dedicated in I.Sinuri 76, discussed above. In any event, the gateway (pylon)

54 The total area of the temenos of Sinuri is calculated at roughly $1500 \mathrm{~m}^{2}$, whereas that of Labraunda was at least $7200 \mathrm{~m}^{2}$; Pedersen (1991), Fig. 99.

55 On the terminology, see Chapter 2.

56 Devambez (1959), 30: “... l'orientation à l'ouest pourrait être rituelle dans le culte de Sinuri: c'est à l'ouest que s'ouvre le petit édifice mentionné plus haut [Archaic small square structure - CGW], vers l'ouest aussi qu'est tourné l'autel rupestre."

57 I.Sinuri 31 was to be inscribed left of the gateway, and nos. 11, 16 (Figure 4.15a-b), 28, and 33 were further to be inscribed on the left doorpost (parastas). 

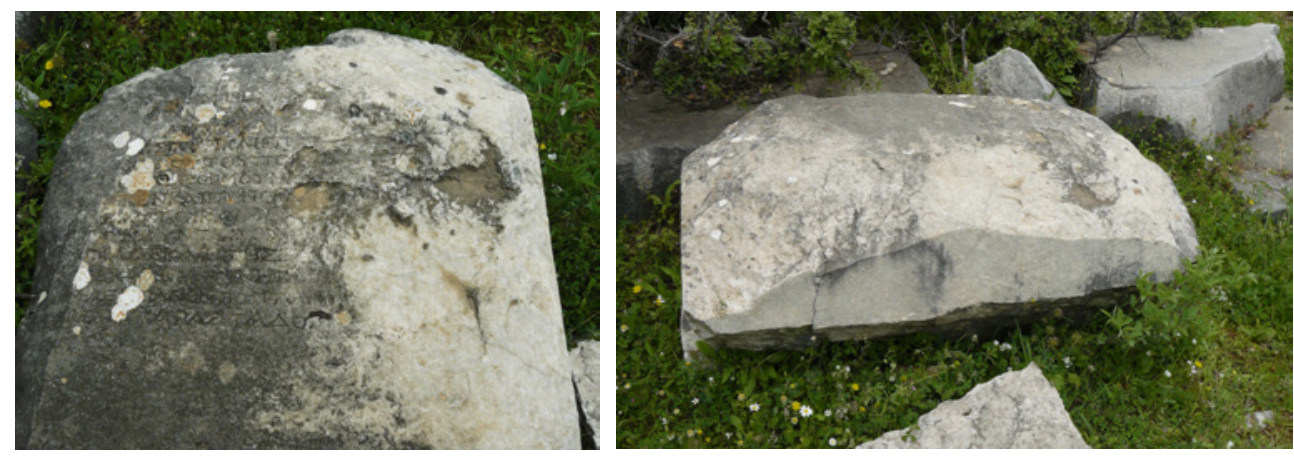

FIGURE 4.22 Two images of the white marble block carrying I.Sinuri 16 . This heavily damaged block, measuring $100 \times 62.5 \times 52.5 \mathrm{~cm}$, bears an honorific decree by the syngeneia of Pormounos for $[\mathrm{Ou}]$ liades $\mathrm{Po}[\ldots]$. The image on the left shows the text, indicating that this block was set up vertically. The last line states that it is to be erected on the left parastas ([ $[\dot{\varepsilon}] \nu$ $\dot{\alpha} \rho \sigma \tau \varepsilon p \hat{\alpha} \pi \alpha \rho \alpha \sigma \tau \dot{\alpha} \delta 0[\varsigma])$. The image on the right shows the smooth side; presumably this was the left door jamb (parastas) of the gateway (pylon) mentioned in the inscription PHOTOS AUTHOR 2008

was clearly an attractive place for the honorific decrees by the syngeneia of Pormounos in the second and first centuries BC. These inscriptions even specify whether they were to be set up on the left or right side, and if this was as one entered or exited the complex. Some designate a location on the same lateral side of the entrance, i.e. on the left as one enters or on the right as one exits, indicating a favored spot. ${ }^{58}$

Figure 4.22 shows the fragmented inscription of I.Sinuri 16, an honorific decree for a certain Ouliades, that was to be set up on the left door jamb (parastas); the right face of this block is smooth (Figure 4.22), indicating that this was in fact the left door jamb. The entrance to the sanctuary was obviously a place where everyone had to file through, and setting up monuments and inscribing honorific decrees and contracts on the walls and even the doorpost itself heavily emphasized this place, thereby heightening its already public function. ${ }^{59}$ People entering or leaving the sanctuary were thus exposed to a

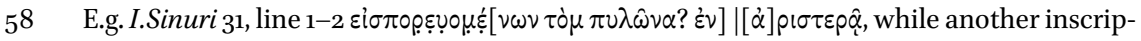
tion, concerning a land-lease contract, states that it is to be inscribed on the 'right' side

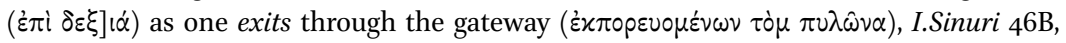
lines 15-16. See further Robert's discussion in I.Sinuri, p. 54 .

59 See the discussion above, on the findspots of I.Labraunda 9 next to the South Propylon at Labraunda; a possibly adjoining inscription is to be set up 'in the most conspicuous

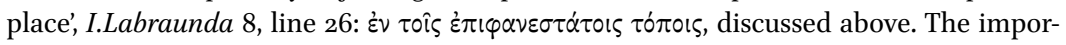
tance of such location clauses is further addressed in Roels (2018a). Sokolicek (2009), on the Magnesian Gate in Ephesos, provides a good discussion (with references) on how 
kind of 'saturation advertising' ${ }^{60}$ By micro-managing the locations of these inscriptions, the syngeneis were clearly emphasizing this spot as a critical node in their kinetic linear space, much like the South Propylon at Labraunda, or the propylon of the sanctuary of Hekate at Lagina. ${ }^{61}$ Spatial studies have shown that gateways are key public places not only because of their transitional role, but especially for their popular isovist shapes that connected spaces, allowing for a sheltered but strategic overview before one actually enters either area. ${ }^{62}$ The propylaia of Labraunda and Lagina certainly appear to have had this function, and, although we know nothing about the layout of the monumental gateway of the sanctuary of Sinuri, it is likely that it was designed in a similar fashion, perhaps with a view across the valley.

\subsubsection{Sacred Road}

As stated above, the number of inscriptions specifying their placement at the entrance of the sanctuary shows that this was a highly public spot; this is no doubt connected to its formal role as gateway during the festivals and probably implies some kind of procession and ritual entry. ${ }^{63}$ The exact location of this entrance is unfortunately unknown, although the excavator believes to have found some traces of an opening in the western wall that was also blocked at a later stage (like the entry in the Archaic wall). ${ }^{64}$ This could correspond with the large level area just west of the sanctuary, also covered with tile and pottery fragments.

Another possibility could be in the northeastern area, which was heavily disturbed by the Byzantine constructions (see plan, Figure 4.6). Directly north of the temenos there is a path, roughly $2-3 \mathrm{~m}$ wide and partly cut from

gateways in general could mark the connection between a community, the gods, and the surrounding region.

6o Chwe (2001), 20-21, compares for example processions to 'saturation advertising' by bringing the message past all the members of a community; such gateways have the same effect, although an opposite mechanism, by having all the members of the community pass by these static 'messages'.

61 For Labraunda see Chapter 3 , and Chapter 5 on the sanctuary of Hekate at Lagina.

62 See Benedikt (1979) and Batty (2001) on isovist fields, discussed in Chapter 2. The importance of such spatial hinges is further discussed in connection with the public function of the pronaos, Roels (2018b), also (2018a); on the attraction of temple doorways, Williamson (2018).

63 Similar e.g. to the South Propylon of Labraunda, discussed above; the sanctuary of Meter at Mamurt Kale, near Pergamon, by contrast, does not have a formal gateway, or propylon; it is unknown whether worshipers went there collectively or more as pilgrims, see Williamson (2014a).

64 Devambez (1959), 30: "J'ai cru cependant reconnoitre dans le mur oust de tracé d'une porte qui, par la suite, aurait été bouchée." 


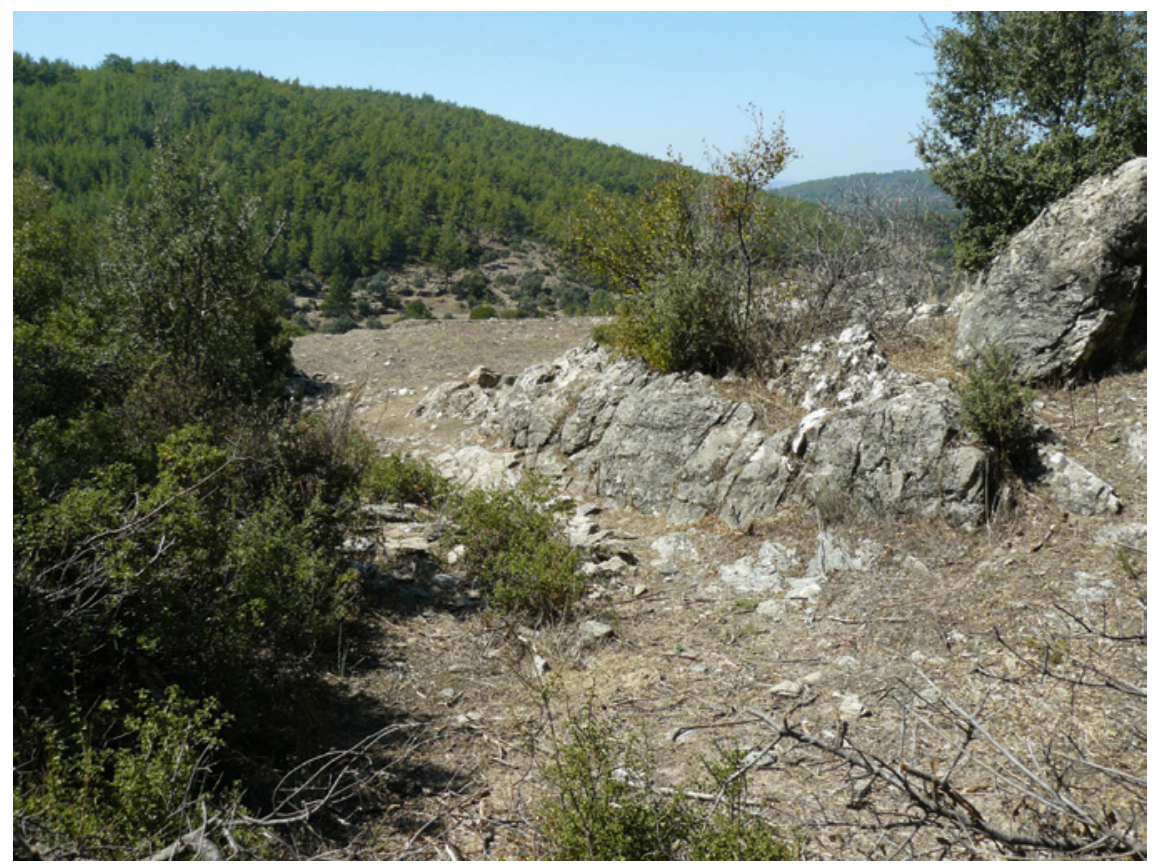

FIGURE 4.23 Sinuri. Path northeast of the sanctuary, leading onto the area north of the sanctuary; the vaulted tombs from the Roman period are just around the rocks to the right PHOTO AUTHOR 2010

the rock, leading further to the northeast and eventually to the 'acropole' (Figure 4.23). There is a high concentration of sherds in this area, but a surer sign of its antiquity are the two tombs from the Roman period, immediately north of this path. ${ }^{65}$

The course of the path beyond the sanctuary remains unknown, since the recent or sub-recent terracing of the hillside will have destroyed much of the original surface. However, scatters of ancient pottery and roof-tile are found all across this hilltop, with high concentrations immediately north of the sanctuary, as well as beyond, in a large halo around the 'acropole' as discussed above (also Figure 4.19). ${ }^{66}$ The rock-cut 'steps' and rectangular rock-cut tomb testify to further activity in this area, as previously mentioned. ${ }^{67}$ Only a systematic survey, however, will reveal the extent and nature of activity in this area.

65 The tombs were also excavated but empty Devambez (1959), 31-32.

66 Personal observation, 14 September 2010.

67 Shown by a resident of Aşağı Kalınağıl who guided us through the site on 18 April, 2008. 
From the west and Mylasa, the most logical route to the sanctuary would have been through the valley, as described above. From here it is likely that worshipers or travelers would not have crossed up the steep western face, but would have circled the hill along its more gradual ascent via the southern side, where they could also admire the imposing southeast retaining wall where the Archaic entry was located, then continuing along the eastern flank until they reached the new entry in either the northern side, or circling further beyond this to the western side.

To summarize, despite the paucity of data, the construction activities on this hilltop lead to a number of insights regarding ritual space. While the shrine of Sinuri did not occupy a commanding position in the region as did Labraunda, its location on the low hill just above the valley floor would have made it a local landmark. The snapshot-like view of this valley with the road towards Mylasa created a single coherent 'visual region', with this sanctuary at its head. ${ }^{68}$ By increasing the overall prominence of the shrine through the extensive remodeling, the Hekatomnids put the shrine of Sinuri on a par with two other major Karian sanctuaries - that of Zeus Labraundos, and Artemis at Amyzon. As with other Hekatomnid projects, this entailed elevating the shrine via a monumental platform. This also greatly expanded the useable area of public space for a sizeable crowd. As the old entrance in the southern wall was blocked, the new entrance will have given the temenos a new spatial syntax and a different appreciation of both external space, through the views linking it to the surroundings, and internal space within the complex. The addition by the Pormounos syngeneia of a stoa on the eastern edge further defined the area south of the altar as an 'inward-facing' space, heightening collective focus on the ritual events while facilitating mutual observation. ${ }^{69}$ This concentric articulation of space increased the effectivity of ritual while promoting cooperation within the community.

\subsection{Ritual Performance at the Sanctuary of Sinuri}

As discussed above, the rituals for the god Sinuri may well have been related to the general western orientation of the sanctuary. ${ }^{70}$ Little is actually known of the rituals themselves, however. The ceramics have not been studied in enough detail to reveal changes in ritual, although give a broad indication of the

68 The concept of visual regions is discussed in Chapter 2 and above with respect to Labraunda; also Williamson (2016b).

69 Chwe (2001), 30-33. This concept is explained in more detail in Chapter 2.

70 Suggested in Devambez (1959), 30. The westward facing features include the rock-cut altar, the small square Archaic structure, and the Doric stoa. 
activities at the sanctuary. Inscriptions remain our foremost source of information as to ritual use of the shrine.

\subsubsection{Festivals}

What little is known of the festivals at the sanctuary of Sinuri under the Pelekos syngeneia derives primarily from a fragmented inscription dated to the fourth century BC and concerning a certain Nesaios, who was granted admission into the Pelekos syngeneia during a festival. ${ }^{11} \mathrm{~A}$ second inscription from this period mentions a festival that Robert restores as the Syennia. ${ }^{72}$ Together these give a glimpse into the fourth century shrine as a place where constitutional matters that concerned the Pelekos syngeneia were determined and announced through festivals.

By the Hellenistic period, the festivals appear to have been reorganized by the Pormounos syngeneia during their administration of the sanctuary. Their main festival, or "la réunion annuelle," according to Robert, was apparently called the Kotamia, an indigenous designation; it is, however, more often referred to simply as the bouthysia, or 'oxen sacrifice. ${ }^{73}$ This syngeneia used the same Macedonian calendar as Mylasa and their festival took place in the month of Loos, in the summer. ${ }^{74}$ Music would have been part of the festivities, as witnessed by a single tantalizing fragment with musical notations that was discovered at the sanctuary, although its date has not been determined. ${ }^{75}$

The climactic ritual at the sanctuary was the sacrifice, and excavations revealed a rock-cut altar (shown on Figure 4.6). Hekatomnos personally dedicated an altar table (trapeza), according to I.Sinuri 76 and he may well have been responsible for the expansion of the precinct area, which greatly increased the space around the altar. Another altar was dedicated in the second or first century вС by the treasurers (tamiai) and the legal representatives (egdikesantes) of the Pormounos syngeneia, as testified in I.Sinuri $2 .{ }^{76}$ Figure 4.24 shows the

$71 \quad$ I.Sinuri 73 . The constitutional administration of the syngeneia via the shrine is discussed further below.

72 I.Sinuri 74 , line 6.

73 Robert reconstructs the name of the festival from two fragments: I.Sinuri 17a, line 5, and

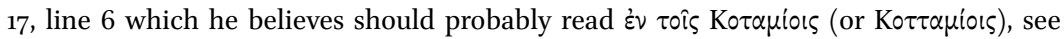
I.Sinuri p. 45. Wilhelm's suggestion that the kappa should in fact have been a beta, for a more faunal Botapiors (Wilhelm (1947), 8-11) is dismissed in Robert (1949), 6o-63. The bouthysia is mentioned in I.Sinuri 11,24 and 25 .

74 The month of Loos (roughly July) is mentioned in I.Sinuri 9, 11, and 25. On the calendar at Sinuri, Robert, I.Sinuri p. 31.

75 I.Sinuri 81 and p. 104-106. Pöhlmann and West (2001), 86.

76 This was also the inscription which aided Louis Robert to identify the site in 1934, I.Sinuri p. 16. The dedication of this altar to Sinuri had to do with the affair concerning the sacred 


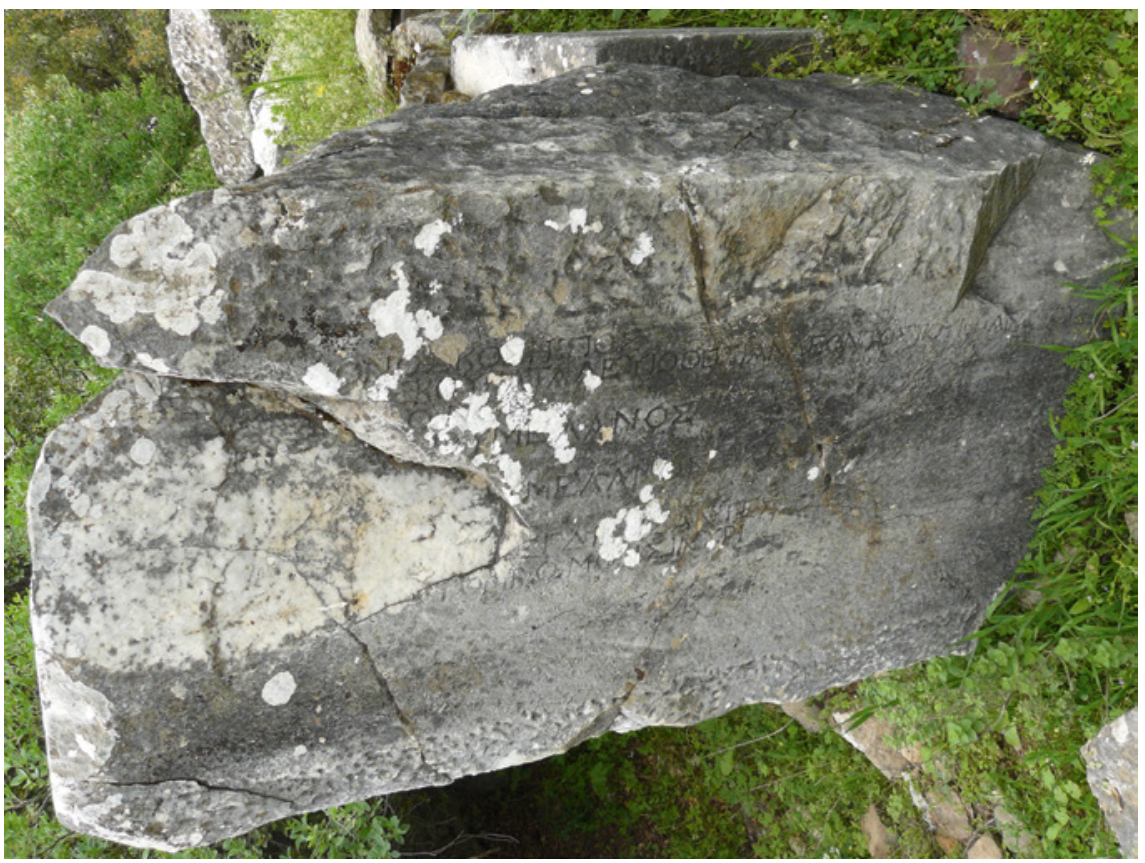

FIGURE 4.24 White marble block with the inscription I.Sinuri 2 . This block (shown sideways), $67 \times 130 \times 47 \mathrm{~cm}$, bears the dedication of an altar to Sinuri by the seven treasurers (tamiai) of the syngeneia of the Pormounou. Based on this inscription, Louis Robert was able to identify the site as the sanctuary of Sinuri (the block has since been damaged at the top). Its current position reflects its secondary use as an orthostat in the Byzantine basilica PHOTO AUTHOR 2008

large block bearing the inscription. The workmanship on the edges is different than the architectural blocks, possibly an indication of the incorporation of the block in the altar that was dedicated, but the markings could also be due to the later Byzantine use of the stone.

The oxen sacrifice, the bouthysia, would have been the main annual event for the syngeneia, whether this was during the Syennia (for the Pelekos syngeneia in the fourth century) or the Kotamia (for the syngeneia of Pormounos in the Hellenistic period). One inscription mentions the sacrifice 'to the ancestral gods, ${ }^{\prime 7}$ perhaps the Pormounos syngeneia combined in this way their own

wood, mentioned in this inscription in line 9, and more in I.Sinuri 11-14, discussed below.

77 I.Sinuri 10, lines 4-6 concern the progonikoi theoi; see also Robert p. 21-22, and Laumonier (1958), 178-179, who takes these 'ancestral gods' together with the 'savior gods' (i.e. Samothracian gods) from a dedication by the priest Menippos, son of Hieronymos 
ancestral heritage with the god Sinuri? Besides the festivities, it was also the time when the syngeneia held council, making decisions that concerned the community or the sanctuary, as some of the preambles of decrees show. ${ }^{78}$ This is when new members were admitted as citizens into the community and contracts concerning land-leases were sealed - these will be discussed below. But this is also when individuals were honored, such as Dionysios, son of Leon of Kosetios in I.Sinuri 11. The decree on the construction of a stoa is also dated to the month of the Loos, the same month in which the festival took place, and which honors those who made the stoa possible. ${ }^{79}$ In all likelihood the decisions by the syngeneia to honor members of their community were both taken and performed during these festivals. The awards were often a golden crown or statue, ${ }^{80}$ but significantly 'also a portion [of meat] from all the sacrifices performed by the syngeneia.81 This emphasis on the syngeneia and the recurrence of the honors in the phrasing of this award shows that meat was more than just a gift: the honorand was clearly given a privileged part of that which was shared by the entire syngeneia - and not just once, but each time. This practice was common to Mylasa, where it was not the polis but the phyle and syngeneia that typically honored outstanding members of the community with a golden crown (and sometimes a statue) and a reserved portion of meat from every communal sacrifice. ${ }^{82}$ Sacrifices were more than a religious performance or collective experience, they were also used to reinforce good behavior

(I.Sinuri 8) as a sign that Sinuri was gradually changing from a god centered on the kinship ties (i.e. the syngeneia) to one more open to outside influences.

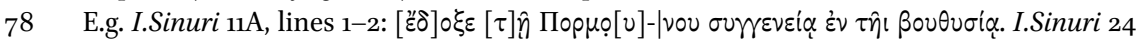
and 25 also refer to decisions made by the Pormounos syngeneia during the bouthysia.

79 I.Sinuri 9 , lines $2-3$.

8o I.Sinuri $11 \mathrm{~B}$, line 7 , and I.Sinuri 16, 18, 20-22, 37 mention golden crowns; I.Sinuri 16, lines $3^{-5}$, includes a bronze statue to be erected in the sanctuary.

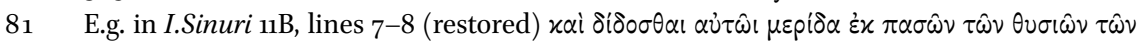

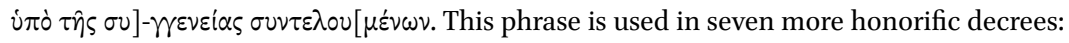
I.Sinuri 16, 18-22, 32; see also Robert's discussion on p. 54.

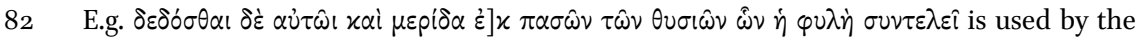
phyle of the Otorkondeis in I.Mylasa 113, line 9, with a similar phrasing in I.Mylasa 117, lines 3-5; another Mylasan phyle, the Konodorkondeis, uses similar phrasing, only they substitute 'from every sacrifice' with 'lifelong from the sacrifice' ( $\tilde{c}^{\omega} \omega \zeta \zeta[\omega \hat{\eta} \varsigma \dot{\varepsilon} \chi] \mid[\tau \hat{\omega} \nu \theta \nu \sigma l]$ Wv), I.Mylasa 119, lines 11-12 and 17-19; also by an unidentified phyle in I.Mylasa 136, line 11, and 140, line 11; and by the Mylasan syngeneia of the Aganiteis in I.Mylasa 121, line 4-5, who celebrate their sacrifices in the (as of yet unidentified) sanctuary of Zeus Aganiteon.

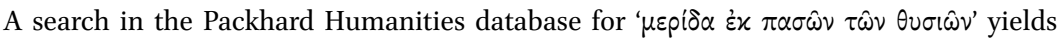
results only from Mylasa and the sanctuary of Sinuri, which may imply the peculiarity of this phrasing to Mylasa in the Hellenistic period. 
by perpetuating the memory of the social pillars of the community, thereby maintaining group identity. ${ }^{83}$

\subsubsection{Banqueting}

Sacrifices usually end in a festive banquet. Water would have been a requisite in any event for a large gathering, perhaps also for rituals. There is a well at the site although the date of this is unclear. ${ }^{84}$ Other water facilities must have been available but are unknown. The four large storage jars (pithoi) were presumably for some kind of food preparation, although these apparently date from the earlier Archaic period. ${ }^{85}$ Most of the pottery described in Devambez' report refers to tableware, with the largest quantities also deriving from the Archaic period; several fragments show Orientalizing, Black-Figured and Red-Figured ornamentation. ${ }^{86}$ The following periods are poorly represented, although two mould-made bowls were discovered from the second century вс. ${ }^{87}$ Nonetheless, in the fourth century and later, banqueting would still have been part of the rituals, and a new examination of the ceramics would surely reveal more material from these periods that may be linked to this activity. Also, the stoa (or stoas) would have provided banqueting facilities, at least as shelter, even if there were no andrones for banqueting in symposium. ${ }^{88}$ An inscription from the second century mentions the construction of a stoa at the eastern part and honors the syngeneia's financial treasurer who provided funding for it along with a banquet for the entire syngeneia. ${ }^{89}$

In sum, the ritual activities that may be discerned at the sanctuary of Sinuri reinforce the image created by architectural developments in the Late Classical and Hellenistic period. While the new design of the sanctuary created a concentric space for a large gathering, the festivals created the collective experience, as the decrees discussed further below will reveal in sharper detail. The focus on the syngeneia runs parallel to urban festivals that centered on the polis. Unsurprisingly, the main sacrifice played an especially strong role in

83 On the political role of sacrifice, see e.g. Bruit Zaidman and Schmitt Pantel (1992), 34-36; on the communal role, Schmitt Pantel (1990), and (1985), on banqueting in general.

84 The central large dot in Figure 4.8.

85 Devambez (1959), 14-15, Pl. IV, Fig. 4 and Pl. xIV, Figs. 2-3.

86 Devambez (1959), 15-23, Pl. XXII-XXVII.

87 Devambez (1959), 30-31, Pl. xxviII. The terracottas include a head of Aphrodite, a relief of Eros (perhaps from a vase); part of a terracotta lion's head was also found, probably Roman.

88 Stoa architecture is typically associated with banqueting, Börker (1983) and Kuhn (1985).

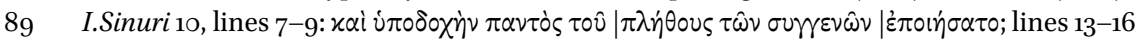

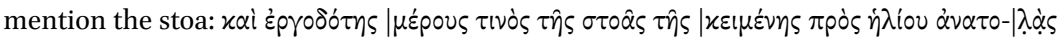

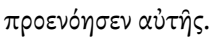


structuring community. The deliberate repetition of honors via reserved gifts of meat during the climactic ritual, year after year, created and reinforced shared memories, thus perpetuating the identity and values of the syngeneia. The divine authority invoked via the sacrifice was both focus and channel. While this deviates from the standard view of Greek polis sacrifice with distributions of equal portions of meat as way of propagating equality, or isonomia, ${ }^{90}$ the ultimate goal of this syngeneia was similar - namely their collective identity. Individuals who did what they could to protect this identity, through benefactions, good deeds, or accomplished services, were worthy of being singled out to be honored and remembered. The sacrifice was obviously the central event of the festival that focused everyone's attention. The ritual would have been simple, following a pattern known to everyone. ${ }^{91}$ Linking honors to individuals with the communal sacrifice was a natural way of building collective memory, thereby perpetuating group identity. ${ }^{92}$ Performing this together in the concentric space before the altar may certainly be understood as a 'rational ritual. ${ }^{93}$ Though at a different scale, the rituals of Sinuri reinforced the syngeneia in much the same way as urban rituals: members were honored, common events were commemorated, and financial needs were secure, all according to institution and protocol.

\subsection{Legal Administration and Organization of the Sanctuary of Sinuri}

The identity of the syngeneia administering the shrine changed from the Pelekos in the fourth century to the Pormounos in the third century. This section examines differences in how these syngeneiai organized the shrine, the role of its priests, the composition of the community, and their financial administration. Through this it will become apparent not only how tight the bond was between the sanctuary and this community, but also how embedded this was in the landscape around Mylasa. It will furthermore give insight into

9o On the isonomic intentions behind sacrifices in the Classical democratic city, see Bruit Zaidman and Schmitt Pantel (1992), 34-36; also Bremmer (2007), who considers the weighing of meat at the sacrifices of Sinuri as an indication of equal distribution. Roman sacrifices could have the opposite effect, by publicly reinforcing hierarchical distinctions, Scheid (1985). Paul (2018) places sacrificial division within the fluid boundaries of participation along with processions.

91 The importance of ritual performance as creating cognitive pattern recognition is discussed further in Chapter 2; see Chwe (2001), 27-30, esp. 28 with his discussion of Tambiah (1985) on ritual and pattern recognition.

92 Connerton (1989), 44-61; McCauley and Lawson (2007) for the mnemonic effects of ritual; discussed in further detail in Chapter 2 and below.

93 Chwe (2001). 
the transformation of such syngeneiai from independent political entities to subsidiaries of the polis in the Hellenistic era.

\subsubsection{Administration and Priesthoods}

An inscription found at the sanctuary gives a list of priests containing 16 names in three columns. ${ }^{94}$ These represent consecutive priesthoods beginning in the fourth century вс. The first priest is Pellekos, and may well have been the eponymous founder of the Pelekos syngeneia, also known from I.Sinuri 73, discussed below. Robert observes that the first five names in the list are Karian, while the next ten are Greek. ${ }^{95}$ The Greek names Menippos, Iatrokles, Aristeas, and Dionysos were common in Mylasa, as Robert points out, as was the Karian name of Thyssos. ${ }^{96}$

Another name that stands out is that of Hiereus. Robert notes the singularity of naming an infant Hiereus ('Priest') but associates it with the lifelong and hereditary position at this stage, assuming that the next in line was thus designated at birth. ${ }^{97}$ This priest, Hiereus, made a dedication to Sinuri, found at the 'acropole' to the north, and perhaps another one, for his wife, at the sanctuary. ${ }^{98}$ His grandson, Menippos, son of Hieronymos, and thirteenth in the list, dedicated his priesthood (in the service of Sinuri) to the 'savior gods' after he was rescued from 'great and incredible dangers'. ${ }^{99}$ Robert interprets these 'savior gods' as the Dioskouroi or Kabeiroi, or the Samothracian Gods, whose cult was known in Mylasa. ${ }^{100}$ At the sanctuary a sculpted stone was found in the

94 I.Sinuri 5 . The inscription begins with the header 'Priests of Sinuri'; the sixth name is illegible.

95 I.Sinuri 5, p. 19: The first five names are Pellekos, Thyssos, Yssollos, Arteimes, and again Pellekos; the sixth name is illegible. The next ten names are: Menippos, Iatrokles, Hiereus, Iatrokles, Menippos, Hieronymos, Menippos, Aristeas, Demetrios, and Menippos. On the name Pellekos, see Laumonier (1958), 182-183, and below.

96 See Robert in I.Sinuri 5, p. 19: e.g. a certain Thyssos Sysko was accused of being involved in the complot against Maussollos, and his property taken away, I.Mylasa 3. A Thyssos Imbrassidos and a Thyssos Sambaktuo were witnesses of sales of land during the reign of Maussollos, I.Mylasa 11 and 12 resp., from the fourth century. In the third century a certain Thyssos son of Apollonios was treasurer of the Otorkondeis phyle at Mylasa, I.Mylasa 201.

97 Robert in I.Sinuri 5, p. 20.

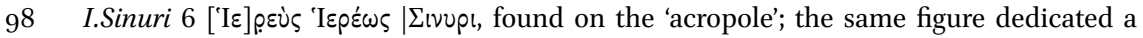
statue of his wife at the sanctuary of Sinuri, I.Sinuri 7. Also I.Sinuri 45 mentions a priest named Hiereus, of the Tarkondareus syngeneia, discussed below.

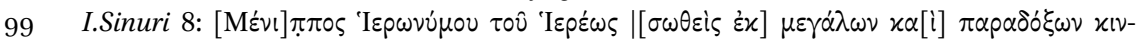

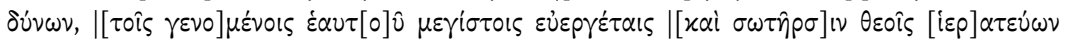

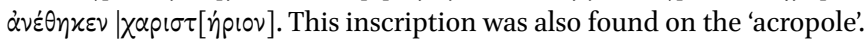

100 I.Mylasa $801,803,804,814$ and 816a, c, and e, 820, 821, and 822 mention a priest (Diodotos Melanos, son of Politos) of the Dioskourides at Olymos in connection with land 
shape of a cap with star, characteristic of the Dioskouroi; perhaps it was may be connected with this inscription. ${ }^{101}$

Based on the shape and style of the letters, Robert dates the inscription bearing the list of priests to the same general period when most of the inscriptions were produced at the sanctuary of Sinuri, i.e. between the second and first centuries BC, even though the list goes back to the fourth century. The length of time and the number of priests indicate that the priesthood of Sinuri was a lifelong position, rather than annual, and the various dedications point moreover to a hereditary post, though not necessarily generational since it seems to have gone from brother to brother on occasion rather than father to son. Robert was thus able to chart a tentative genealogy of the 'Greek' priests, starting with Menippos, even though he was unable to provide specific dates for each of the priests. ${ }^{102}$ Now, however, it appears that the same Hiereus mentioned above, who was the ninth priest, held office in the second part of the third century вс, as he is also mentioned in Olympichos's dedications of lands to Zeus Osogollis. ${ }^{103}$ Hypothetically, then, Hiereus's grandson Menippos, son of Hieronymos, could have been priest during the presumed raids of Antiochos III's troops on the domains of Sinuri - he may even have been one of those taken hostage. ${ }^{104}$ This would be one explanation for the 'great and incredible dangers' that he survived and hence his gratitude and dedication to the 'saving gods'. ${ }^{105}$

This list is thus interesting for different reasons. Besides showing the hereditary nature of the priesthood, it also exemplifies the increasing 'Hellenization'

descriptions; I.Sinuri 47a and 49 are dated to the year when the priest of the Samothracian Gods was the stephanephoros of Mylasa.

101 Robert in I.Sinuri, p. 22. The cap-shaped stone is shown on Pl. vilI.

102 I.Sinuri, p. 22, for the genealogy, with a discussion on p. 24-25. Robert surmised that the first six or seven priests would have been enough to carry the priesthood down from the fourth to the second century $\mathrm{BC}$, presuming a more rapid succession after this period. However, the office of the ninth priest is now dated to shortly after the mid-third century $\mathrm{BC}$, see discussion.

103 I.Labraunda 8C, line 30, as restored by Piejko (1990), 137 no. 8, following Debord

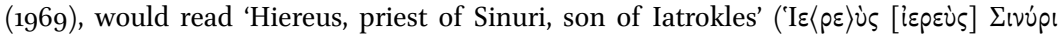

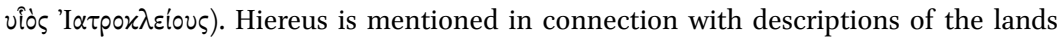
adjacent to those that Olympichos dedicates to Zeus Osogollis. The inscription is from Labraunda and is dated to c. 240 BC but was recut in the second century BC; see Chapter 3 , Labraunda, and below.

104 This event took place in 203-201 BC, when Mylasa sided with Rome against Antiochos III; the capture of sacred personnel and their property is based on Virgilio's analyses of fragments of royal correspondence between Antiochos III and the sanctuary, Virgilio (2010), discussed below.

105 I.Sinuri 8, discussed above. 
of the population, as Robert suggests. Also, somewhere in this list the administration of the sanctuary changed hands from the Pelekos syngeneia, who ran it in the fourth century, to the syngeneia of Pormounos, from especially the third century on. ${ }^{106}$ It is tempting to correlate this with the shift from Karian to Greek names, yet there is no sound base for this: Greek and Karian names occur in Mylasa throughout both periods. ${ }^{107}$ In fact, this list seamlessly and without interruption continues through the different administrations. Perhaps it was copied from earlier archives no longer extant, or may even have been memorized by each successive priest. In any event, the list implies a smooth transition between the two syngeneia, rather than a hiatus or disruptive break.

From the inscriptions in Mylasa we know of at least two more priests of Sinuri: Hybreas, son of Krateros, ${ }^{108}$ and Thargylios, son of Aristomenos, who was honored with a statue. ${ }^{109}$ Neither of these names appears in the list of priests in I.Sinuri 5 , and so Robert postulates that they were likely to have been later, after the priestly line died out and the priesthood was no longer a hereditary position. ${ }^{110}$ They are discussed in more detail below with regard to their urban contexts.

106 On the transition from the Pelekos to Pormounos syngeneia, see below.

107 Debord (1982), 51 on the common use of Greek names. Piras (2010), 225-229 on the resurgence of Karian names at Mylasa in the third century, also discussed above in connection with Labraunda. Also Aubriet (2013), 196-197 who discusses the list of priests in the context of a resurgence of Karian identity, particularly noticeable at the two extra-urban sanctuaries of Mylasa.

108 I.Mylasa 103, lines 1-2 mention Hybreas, son of Polykritos, who was the stephanephoros of Mylasa and the adopted son of Hybreas, son of Krateros, priest of Sinuri and secretary of the council; Hybreas, son of Krateros, is mentioned again as priest of Sinuri in a land-lease document in I.Mylasa 217, lines 6-7 (Blümel et al. (2014) nos. 2 and 3). Robert (I.Sinuri p. 25) believed the Pixodaros mentioned in this inscription was also a priest, but

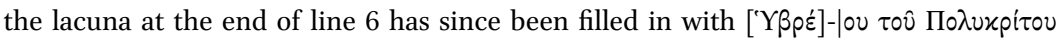
(Blümel (1992), 16), referring to the same individual in I.Mylasa 103 (Blümel et al. (2014) no. 17).

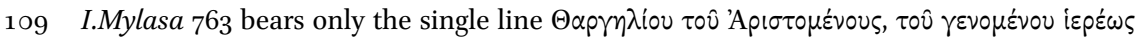
$\Sigma(v 0 \rho 1$, but it would have been an honorific award from the demos or maybe one of the phylai.

110 I.Sinuri, p. 25; Robert on the later period of the priesthood: "Je suis amené à former l'hypothèse suivante: à un moment (peut-être dans la seconde moitié du II ${ }^{\mathrm{e}}$ siècle) la famille où se recrutaient les prêtres de Sinuri, celle de Pellekôs, s'est éteinte; on a alors

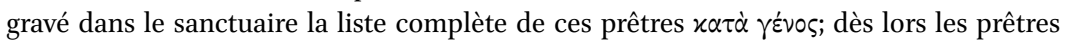
ont été choisis par la ville ou plutôt par la syngeneia, sans conditions de famille; étant donné la coutume à Mylasa à cette époque, on peut supposer que le sacerdoce a été mis en vente." A parallel for this would be the syngeneia of the Maunnites, who issued a decree posting their priesthood for sale, I.Mylasa 3 о2, dated to the first century вс. 
The priesthood may have been hereditary, but other cult officials were elected, more in symmetry with polis cults. These include the treasurers (tamiai), the commissioners in charge of maintenance of the sanctuary (ergodotai), the legal representatives (egdikoi), and those responsible for the management of the sacred lands (ktematonai). These offices were directly connected to both the community and the economy of the shrine and are further discussed below.

\subsubsection{Local Community - the Pelekos and Pormounos Syngeneiai}

Prior to the surge of synoikism in the Late Classical and Hellenistic periods, syngeneiai were the base political unit of Karian society. As such they were generally independent communities, often with a sanctuary at their center which they held in common. As their name implies, syngeneiai were typically rooted in kinship ties, often based on a mythical or legendary ancestor; sometimes such ties were invoked for political or economic favors. ${ }^{111}$ In the Hellenistic period, however, these once autonomous entities were typically subsumed by an expanding polis, in which they became a sub-division, under the phyle or demes. ${ }^{112}$ As mentioned above, in the fourth century вс Mylasa knew three tribes, or phylai: the Otorkondeis, the Konodorkondeis, and the Hyarbesytai. ${ }^{113}$ By the Hellenistic period, a number of syngeneiai were added to these, e.g. the Tarkondareus and the Maunnites were part of the Otorkondeis, while the Aganiteis belonged to the phyle of the Hyarbesytai. ${ }^{114}$

One of the earlier inscriptions found at this sanctuary is I.Sinuri 73 , a fourth century decree by the Pelekos syngeneia. ${ }^{115}$ Robert believes that this syngeneia was named after the priest, analogous to the syngeneia of Korris at

111 See below in Chapter 6, in connection with the sanctuary of Panamara, when various syngeneiai across Karia were called upon to engage in the cult.

112 E.g. the syngeneia of Korris at Labraunda was made up of citizens from Mylasa, see above. When Olymos was absorbed by Mylasa, the city's phylai, e.g. the Mosseis, were 'downgraded' into syngeneiai so they could then be incorporated into the phylai of Mylasa, e.g. I.Mylasa 863 on the division of Olymos and Labraunda into phylai, syngeneiai and patra; Cousin and Diehl (1898), 434-439 (e.g. the deme of the Maunnites in Olymos became a syngeneia of the Mylasan phyle of the Otorkondeis); Robert, I.Sinuri p. 26-27; Crampa in I.Labraunda, p. 25; Reger (2004), 164-168.

113 Presumed to be the same three phylai that ratified the decisions of the ekklesia kyria in I.Mylasa 1, 2, and 3, also mentioned above.

114 On the Tarkondareus and Maunnites, see e.g. W. Ruge in $R E$, s.v. 'Mylasa', 1055-1056; the Maunnites began as a deme of Olymos, see Cousin and Diehl (1898), 435-436 and above. On the Aganiteis, I.Mylasa 121-122.

115 I.Sinuri 73, revised in Robert (1949), 63-67. 
Labraunda. ${ }^{116}$ This inscription, from $35^{\circ}-344 \mathrm{BC}$, bears the only reference to the Pelekos syngeneia, and records their joint decision to admit a certain Nesaios into their community, by mandate of Idrieus and Ada. Nesaios is welcomed as a 'brother', demonstrating the 'fraternity-like' nature of the organization, as Robert points out. ${ }^{117}$ The involvement by Idrieus and Ada in the constitution of the syngeneia further underscores the personal Hekatomnid relations with the sanctuary, not only with the structure of the sanctuary but also with the community that administered it. The directness of this relationship and the lack of any signs of affiliation with Mylasa indicate the relative autonomy of the Pelekos syngeneia - they do not seem to have answered to any intervening level of authority.

No other indications of the Pelekos are known and within a couple of generations a different syngeneia is connected with Sinuri, that of Pormounos. ${ }^{118}$ The earliest unequivocal testimony of their presence is I.Sinuri 44 (Figure 4.25), another decree admitting an individual to the syngeneia and dating from the rule of Pleistarchos at the end of the fourth or early third century вс. ${ }^{119}$ The way in which the decision is formulated, as determined by the entire koinon of Pormounos, is very reminiscent of I.Sinuri 73, where the Pelekos syngeneis all came together to make this decision. ${ }^{120}$

In the second and first centuries BC the syngeneia of Pormounos will show close connections with Mylasa, among others through the formulation of their decrees, supporting Robert's general observation that the position of the syngeneia changes from one of autonomy to one of dependency on the polis

116 Robert in I.Sinuri, p. 95. 'Pelekos' or 'Pellekos' are the names of the first and fifth priests as listed in I.Sinuri 5 . On 'Pelekos' as a possible derivative of 'pelekus', or double-axe, see below.

117 I.Sinuri 73, line 7: $\alpha \delta \varepsilon \lambda \varphi \rho^{\circ} v \dot{\varepsilon} \alpha \nu \tau \hat{\omega} v$, discussed in Robert's commentary on p. 96. This inscription is discussed in more detail below, in connection with Civic expression.

118 The syngeneia of Pormounos is always inscribed in the genitive, as the Pormounou, Robert I.Sinuri p. 29.

119 Pleistarchos was the Macedonian ruler of Karia at the end of the fourth century and early third century, cf. Mastrocinque (1979-1980); Billows (1989), 188-193; Gregory (1995). I.Sinuri 44 shows the admission of Samiades, son of Theodotou, to the syngeneia, discussed further below.

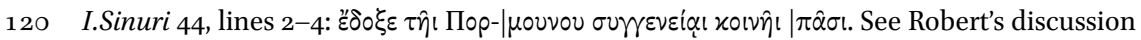
on I.Sinuri, p. 55-56, and 95, showing the similarity between this and the opening lines of

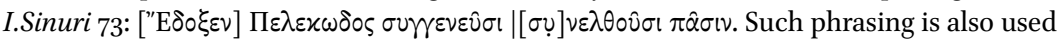
by the Panamareis to honor a Rhodian with citizenship into the koinon, see I.Stratonikeia 6, discussed in Chapter 6. Later decrees by the Pormounos syngeneia use the simpler for-

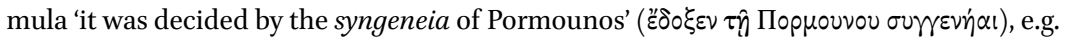
I.Sinuri $9,11,24,25$. 


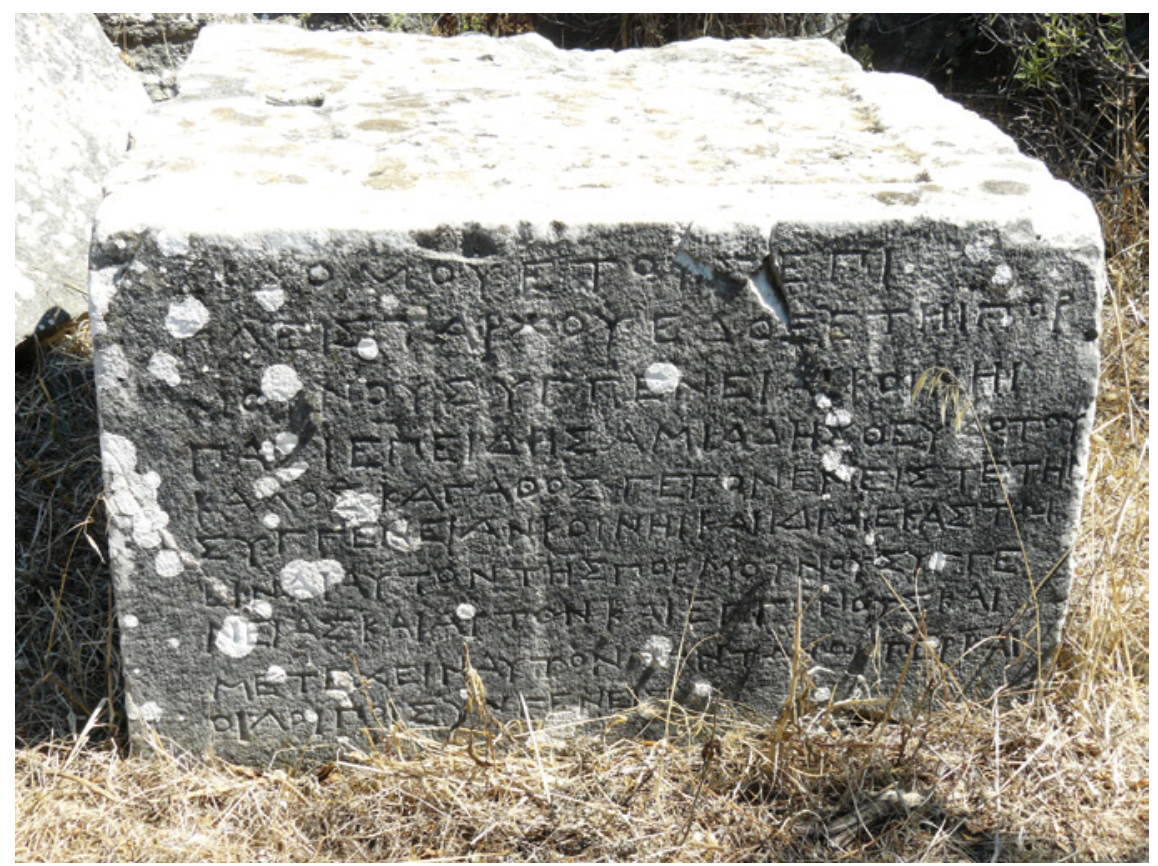

FIGURE 4.25 Ashlar bearing the inscription I.Sinuri 44. This is the earliest mention of the Pormounou syngeneia (end of second and beginning of third lines), an honorific decree in which Samiades, son of Theodotou, is admitted into the syngeneia

PHOTO AUTHOR 2010

in the Hellenistic period. ${ }^{121}$ Yet, as he observes, the sanctuary's takeover by the syngeneia of Pormounos precedes the affiliation of this body with Mylasa - the incorporation of the Pormounos syngeneia into the polis apparently did not happen straightaway, nor can the shift in syngeneia at the shrine be interpreted as a political move on the part of the polis, as tempting as this interpretation might be. ${ }^{122}$ In fact, regarding the transition from the Pelekos to the Pormounos syngeneia, Robert observed how the lettering in the fourth century inscription of I.Sinuri 75, another fragmented decree concerning the Hekatomnids

121 The stephanephoroi of Mylasa date the decrees of the syngeneia on I.Sinuri 9, 11.24-28, 45-47, and 49; Robert in I.Sinuri p. 30-31, 95. There is, however, no evidence that the Pormounos syngeneia was allotted to one of the three phylai of Mylasa. The relationship with Mylasa is discussed more in depth in the next section.

122 "De la fin du $\mathrm{IV}^{\mathrm{e}}$ siècle ou $\mathrm{III}^{\mathrm{e}}$ doit dater le bref décret de la syngeneia pour Samiades (no. 44). Remarquons que le sanctuaire n'est peut-être pas alors encore rattaché à la ville de Mylasa et que nous ne savons à quelle époque se place l'établissement d'un lien entre la ville et le sanctuaire," Robert, I.Sinuri p. 93. 
Ada and Idrieus, allows for reading ПONMOONNOY, which he believes may refer to the Pormounos. ${ }^{123}$ This position has found support in Ignacio-Javier Adiego's study of the Karian texts in these bi-lingual inscriptions. ${ }^{124}$ What the role of the syngeneia of Pormounos at this early time may have been is unclear, but as with the list of priests this interpretation speaks for a gradual transition, rather than an abrupt change. ${ }^{125}$

The second period of bloom at the sanctuary took place in the later second and first centuries. This is when the bulk of the inscriptions appear, and when a stoa was added to the complex, either the Doric stoa (Figure 4.13) or a second stoa. ${ }^{126}$ This is also when the syngeneia is more highly organized, modeling itself on the institutions of the polis. Apparently several treasurers (tamiai) were needed - a group of no less than seven tamiai dedicated together an altar for Sinuri in I.Sinuri 2 (Figure 4.24). ${ }^{127}$ The function of treasurer is further mentioned or implied in several other inscriptions. ${ }^{128}$ Another office is that of the commissioners in charge of managing the sanctuary and its contents (ergodotai), including the building activity. Four such commissioners were charged with overseeing the construction of the stoa in I.Sinuri 9 (Figure 4.14). ${ }^{129}$ The egdikos was the one responsible for giving legal representation of the syngeneia in courts of Mylasa; a cohort of these were appointed when the sacred lands were infringed upon, which will further be discussed

123 I.Sinuri 75, line 3; the Pelekos syngeneia is not attested in this inscription, but appears in I.Sinuri 73. Wilhelm suggested that the syngeneia of Pormounos may be inserted in a

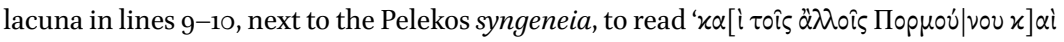

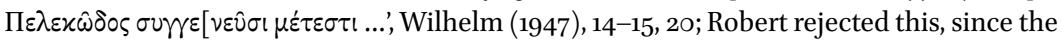
preamble refers to a dedication by the Pelekos syngeneia, in the singular, Robert (1949), 63-67; he does, however, welcome Wilhelm's restoration of $\pi \lambda \dot{\eta} \nu \dot{\alpha} \pi \circ \mu\left[0 i p \alpha \varsigma^{\prime}\right]$ in line 12, discussed above.

124 Adiego (2000), 133-139; he further determined that I.Sinuri 74 is actually a continuation of I.Sinuri 75 , since both part of the same bilingual inscription.

125 This coincides with the list of priests, I.Sinuri 5 , which spans the periods of both syngeneiai. Whoever the 'Ponmoonnou' were, they must have been important since they are listed near the top, in line 3, just after the header which begins with Ada, daughter of Hekatomnos.

126 I.Sinuri 9 and 10 document the construction of the stoa; Pedersen (1991), 103 indicates that the stylobate of the Doric stoa was Hekatomnid; see also the discussion above under Architecture.

127 I.Sinuri 2 , line 8 . This follows an incident regarding the infringement of the sacred wood, see below. On the office of tamiai at the sanctuary in general, see Robert, I.Sinuri p. 34, 44, and 54 .

128 I.Sinuri $11 \mathrm{~B}$, line 8, and I.Sinuri 17, 17a, 46a-c, 46e; also further implied in I.Sinuri 10, 14, and 25 .

129 On the ergodotai, see Robert I.Sinuri p. 29, and p. 33 where he discusses how he believes they 'accepted' this charge in lines 27-28. See also I.Sinuri 9 and 10. 
below. ${ }^{130}$ Finally, a number of ktematonai were appointed to oversee the administration and lease of sacred lands, discussed in the next section. ${ }^{131}$

A final matter related to the syngeneia is the Hiera Kome, or Sacred Village, which appears in some inscriptions. ${ }^{132}$ These all concern land-lease documents (discussed below), and mention Hiera Kome as it relates to the descriptions of the locations of the lands in question. I.Sinuri 47a refers to a plot as being near or just across the road that leads to Hiera Kome, a small but intriguing clue for the otherwise elusive processional route, as well as the location of the sacred village. This same inscription further mentions the property, with vineyards and trees, as being in a place called 'Hysarbida', which is across the road to Hiera Kome, as well as across 'the river', presumably referring to the stream south of Aşağı Kalınağll. ${ }^{133}$ Robert states that the syngeneia was based at Kalınağıll, ${ }^{134}$ although he does not distinguish between Lower (Aşağı) or Upper (Yukarı) Kalınağıl. He suggests that the Hiera Kome could be at the 'acropole' which Devambez discovered on the steep hill immediately north of the sanctuary. ${ }^{135}$ Devambez, however, found no signs of a settlement here, although his justification of this conclusion is meager given the abundant surface record. ${ }^{136}$ Starting about halfway up the hill from the sanctuary towards

130 Egdikoi are mentioned in I.Sinuri 2, 11, 12, 13, and 14.

131 I.Sinuri 15, 47a, 50a. The office of ktematonia is also known in Mylasa, from the phyle of the Otorkondeis, e.g. I.Mylasa 203, 205, 206, 207, 207b, 211, 212, 215, and the syngeneia of the Aganiteis, in I.Mylasa 222; in Olymos the office was appointed by the polis, in connection with the sanctuary for Artemis and Apollo, I.Mylasa 801, 806, 811, and 816a; also at Hydai, where a ktematones was appointed by the koinon to administer the sacred lands of Apollo and Artemis, I.Mylasa 903, and probably 906.

132 I.Sinuri 47a, line 10; I.Sinuri 47b, lines 4-5, 12; I.Sinuri 56, line 3; I.Sinuri 58, line 1, and restored in I.Sinuri 53 , line 7 . Sacred villages, hiera komai, are also known from Labraunda (see above Chapter 3 ) and especially Lagina, where Hiera Kome became one of the demes of Stratonikeia (see Chapter 5). See also Frejman (2020), 131-154.

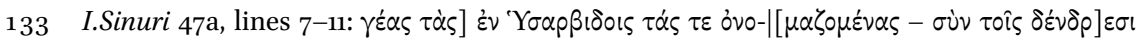

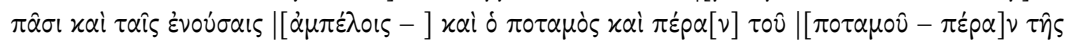

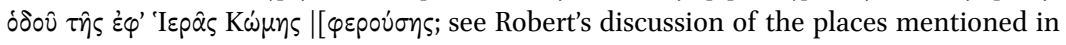
this text in I.Sinuri, p. $77^{-78 .}$

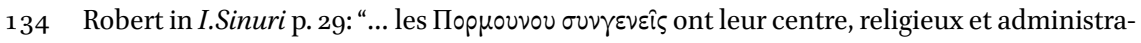
tif, et leurs domains à Kalın Ağıl." Presumably he is referring to the immediate area of the sanctuary here, which would be Yukarı Kalınağıl; the domains, however, were much more dispersed, discussed below.

135 Robert, I.Sinuri p. 78: "Je suppose que ce nom [Hiera Kome] désigne le bourg même voisin du sanctuaire de Sinuri et que c'est le nom antique de Kalın Ağıl, peut-être s'applique-t-il exactement au site habité fouillé par P. Devambez, la petitite acropole à vingt minutes au Nord du sanctuaire."

${ }_{13} 6$ This 'acropole' is where Devambez found the two monumental structures discussed above, Devambez (1959), 5 and 33: "nulle trace d'une agglomeration urbaine n'a été 
the 'acropole' there is a noticeable presence of ceramics along the terraces, including tile indicating buildings, that may well point to some kind of settlement or agricultural activity (Figure 4.19); ${ }^{137}$ the rock-cut tomb shown in Figure 4.20 is just west of this area. A much more likely candidate, however, is Robert's discovery of "un site peu significatif ... le sol est couvert de céramique," which he found on the undulating terrain in the fertile valley close to Aşağ 1 Kalınağll, about 2.5 kilometers west of the sanctuary. ${ }^{138}$ This would of course nicely fit in with the general 'westward' orientation of the temenos of Sinuri, and would even more nicely coincide with the hypothetical processional route from Mylasa, further to the west. It is of course equally possible that settlement in the area followed a much more dispersed pattern, one that might be recognized through intensive survey. This will remain a matter of speculation until the area is more thoroughly investigated.

Wherever the exact location of Hiera Kome was, the question of who lived there remains to be answered. The syngeneia is the most obvious choice place to start. No doubt the village would have housed at least the priest and the sanctuary personnel, as at Labraunda and Lagina. ${ }^{139}$ Yet whether it was home for the entire syngeneia seems improbable. The Pormounos community was obviously thriving in the second and first centuries $\mathrm{BC}$, given the number of officers, their duties, and the economic transactions, discussed below. As stated above, syngeneiai, though based on real or fabricated kinship, were often virtual or even 'imagined' communities ${ }^{140}$ - a syngeneia was thus not necessarily physically bound to a particular village or settlement. ${ }^{141}$ The sanctuary of

retrouvée dans les parages immédiats du sanctuaire, mais un petit établissement, qui n'etait pas un habitat, était installé à 20 minutes à peu près au nord des terrasses que nous avonds étudiées, sensiblement plus haut." Roughly 250-300 m north of the sanctuary, however, I did notice in September 2010 a widespread concentration of ceramics indicative of settlement or agrarian activity.

137 Personal observation, September 2010 and October 2011.

${ }_{13} 8$ Robert, I.Sinuri p. 7; this is where he found the Byzantine fragment I.Sinuri 1, probably related to the Byzantine basilica on the sanctuary of Sinuri; see also Akarca and Akarca (1954), 122.

139 See above, Chapter 3 , for Labraunda, and below, Chapter 5 for the sanctuary of Hekate at Lagina.

140 Anderson uses the term 'imagined communities' to explain nationalism, but realizing how ideologically laden this concept is, he states "it would, I think, make things easier if one treated it [nationalism - CGW] as if it belonged with 'kinship' and 'religion', rather than with 'liberalism' or 'fascism'" in Anderson (1983 [2006]), 5 .

141 It should, however, be noted that in the prosopography of the syngeneia, at least eight

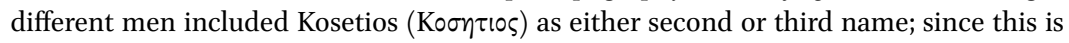
usually in the nominative, Robert suggests that this may have been a place name; see his discussion in Robert, I.Sinuri p. 16-17. 
Sinuri was certainly the religious and administrative center of the Pormounos community, yet they also had strong ties with Mylasa and it is conceivable and even likely that some of its members lived in the urban center. At least some of its sacred lands even bordered on the very edge of the city, in an area called Myrsela. ${ }^{142}$ Also, some of the sanctuary personnel who worked the dispersed sacred lands also appear to have lived on them, as indicated in a fragmentary letter by Antiochos III or his staff instructing his officer Zeuxis to return those who had been kidnapped by his soldiers to the sacred lands and to restore their property. 143

\subsubsection{Economic Resources}

Over a third of the inscriptions concern the lands belonging to the god Sinuri, and most of these involve land-lease contracts. ${ }^{144}$ As briefly discussed above, the area around Mylasa, including Olymos, knew a peculiar hereditary lease construction (misthosis) in the late Hellenistic period, in which land was sold to a sanctuary, then leased back to the original owner and his descendents. ${ }^{145}$ The sanctuary of Zeus Osogollis, combined with the Otorkondeis phyle, has the most extensive set of lease documents that show the various steps involved for each transaction, from intent to purchase, sale, possession, and then hereditary lease, each separately recorded. ${ }^{146}$ The property for lease and all its contents were described in detail, in each documented step, together with the geographical features and the surrounding lands, as shown above. These were

142 I.Sinuri $11 \mathrm{~A}$, line 11 , discussed below.

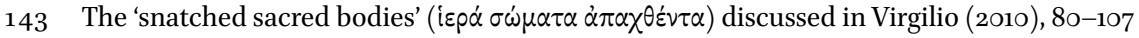
(re-published in Virgilio (2011)). Virgilio deciphered and interpreted the letter mentioned by Robert in I.Sinuri p. 12, with an alternative reading from Piejko (1990), 153-154, no. 2. The reconstruction of Antiochos III as author of the letter was questioned by Errington in $B M C R$ 31.10.2012, who proposes a subordinate instead.

144 No mention is made here of the specific area of the sacred lands, but besides the verdant valley west of the sanctuary, I consider the fertile plain directly east of Mylasa as a likely candidate. One honorific inscription mentions the recovery of sacred lands close to Mylasa, in an area called 'Myrseloi', adjacent to the town, I.Sinuri 11, see below; others were closer to Sinuri; I.Sinuri 47 a, a lease inscription, mentions the land in question being in the area of the 'Hysarbida', across the road leading to the sacred village, see above.

145 I.Mylasa vol. I, p. 74-76, nos. 201-232 (lease contracts), 251-26o (property boundaries) and the lease inscriptions published in connection with the Uzunyuva discoveries, Marek and Zingg (2018), 157-175, nos. 13-19. On Olymos, I.Mylasa 801-854, see Laumonier (1940) and now van Bremen (2016), 14. Gary Reger and Richard Ashton have suggested that the pseudo-Rhodian drachm was especially issued in connection with this land-lease construction, to help the sanctuaries of the polis finance their newly acquired lands, Ashton and Reger (2006), esp. 125-126.

146 E.g. described in Dignas (2002a), 92; Chandezon (2003), 240-241. 
legal contracts, and it was vital that tract of land in question could be properly identified by all parties concerned.

This construction was also applied at the shrine of Sinuri, and the syngeneia of Pormounos handled these transactions much in the same way as did the phyle of the Otorkondeis that administered the sanctuary of Zeus Osogollis at Mylasa. Debord discussed the process in great detail. ${ }^{147}$ At that sanctuary the contracts were also inscribed on the temenos walls, showing their use as a sacred but also public archive. These leases are an indication not only of the management of sacred revenue, but most likely concern the economy of the entire community, whether this is the polis, as at the sanctuary of Zeus Osogollis, or the syngeneia, as at the sanctuary of Sinuri. They will have provided ready cash for those selling their land and a guaranteed long-term income for the sanctuaries at the same time. Yet why there was such a rapid surge of these transactions in the second and first centuries $\mathrm{BC}$, particularly in the region of Mylasa, is a matter of some discussion. ${ }^{148}$ Part of this may be understood in light of the correspondence between Antiochos III, his officer, probably the priest of Sinuri, and perhaps the Pormounos syngeneia or the polis itself. ${ }^{149}$ Most of this correspondence is lost or heavily damaged and Robert excluded it from inscriptions of the sanctuary of Sinuri. ${ }^{150}$ Virgilio's new reading of the text, however, places the sanctuary of Sinuri side by side with Labraunda and especially Amyzon, which, with their wealth and relative remoteness, were

147 Debord (1982), 169: at Sinuri a higher rent was applied for the first ten years, after that it dropped to a symbolic amount, underscoring this as a loan construction. The land was never intended to pass to the god directly - if the rent could not be paid, then the land would be leased out to a new tenant. Debord sees parallels for this in the medieval period, when land is often placed in the hands of God in times of insecurity, for protection, justifying the low rate. Dignas also sees this construction as a way of providing "cheap longterm loans to those who could provide real-estate as security," Dignas 2002, 24. Yet besides the loan, the stress of continued exploitation of the land within the same family is also significant.

148 Laumonier believes this to be a 'curious return' to temple economy, Laumonier (1958), 109, as does Dignas, who attributes it to piety, Dignas (2002a), 95-102, also (2000). But this does not address the sudden increase in these transactions in a time when all other signs point to a major Hellenization of sanctuaries. Debord considers it as a divine security of investment, perhaps in turbulent times, parallel to lease contracts to churches in the medieval period, Debord (1982), 169. Descat and Pernin (2008) relate it to Mylasa returning to an ancient royal practice after its liberation by Rome in the second century BC; the case of Sinuri, however, is at a much smaller scale, having little to do with the polis although mirroring its practices.

149 Virgilio (2010), 91 and 93, on the recipients of the letter.

15 Although he hoped to publish it at a later date, I.Sinuri, p. 12; later included in Piejko (1990), 153-154, no. 2. 
high-risk targets for pillaging during the campaigns of Antiochos III, particularly in the years 203-201 BC. ${ }^{151}$ During this period, Labraunda received a letter of protection, in which Antiochos III instructs his troops to respect and thus avoid the sanctuary. ${ }^{152}$ He wrote a similar letter to the sanctuary of Artemis at Amyzon, but only after his troops had already plundered the sacred lands and taken hostages. ${ }^{153}$ Antiochos thus ordered his commander, Zeuxis, to command the troops to return the kidnapped personnel, or 'snatched sacred bodies', to the sanctuary, safe and sound, and to restore their property; he then did his best to prevent future incursions by declaring the sanctuary and its lands and possessions inviolate (asylia). ${ }^{154}$ By analogy with this situation, Virgilio was able to restore much of the lost text of a similar correspondence between the Seleukid king and the sanctuary of Sinuri.

Virgilio's reading of this text highlights in particular three aspects that are especially relevant to this present study: 1 ) the sanctuary of Sinuri was clearly a lucrative target, like Labraunda and Amyzon, so it must have already had some extensive holdings by the end of the third century $\mathrm{BC} ; 2$ ) these rural holdings were populated, presumably by the people who worked them; and 3) the sanctuary of Sinuri, its people and its property, must have received the privilege of inviolability (asylia). This last aspect, that of protection, may have been an extra incentive for otherwise 'private' persons to sell their property to the god and then lease it back again. The modest rent indicates that this construction was probably as much for the benefit of the lessee as it was for the sanctuary. Besides providing the sanctuary with a steady income from the revenues, and the lessees with an ample amount of ready cash on hand, the property would also have fallen under the security of a divine and especially royal grant of protection from physical violence and financial harm - at least in theory. ${ }^{155}$

That this grant of inviolability was not always foolproof is evident in the degree of legal representation, the egdikos, which the syngeneia needed to defend the sanctuary's rights to its sacred lands in court against the wrongful takeover of these holdings by others. As mentioned above, I.Sinuri 2 shows

151 Virgilio deciphered the letter based on the Louis Robert's documents and squeezes, now available via the Fonds Louis Robert; see Virgilio (2010). On Antiochos III's campaigns in Karia, with his general Zeuxis, as part of his attempt to recover the extent of the Seleukid kingdom, see especially Ma (1999), 66- 71 and $85^{-86}$.

$15^{2}$ I.Labraunda 46, inscribed on the walls of the South Propylon, a logical place for such an announcement.

153 Robert and Robert (1983), no. 18.

154 Virgilio (2010), 80-107, see below.

155 E.g. I.Sinuri $46 \mathrm{a}-\mathrm{c}$ describes how a certain Demetrios sells his land to the sanctuary and agrees to lease it back for a period of ten years at the rate of 200 drachms and some oil; after this period the fee drops to a symbolic 1 drachm; discussed in Debord (1982), 169. 
seven of these attorney-officials (who also acted as tamiai) dedicating an altar to Sinuri, following some kind of incursion of the sacred woods belonging to the sanctuary. ${ }^{156}$ A second inscription, I.Sinuri 11, praises Dionysios, son of Leon, of Kosetios, for his leading role as egdikos in a trial in the courthouse at Mylasa 'against those who attempted to appropriate the sacred lands of Sinuri,'157 which he did, with the help of council or other egdikoi, by presenting evidence of the rights of the god and the syngeneia over these holdings. ${ }^{158}$ One of the main charges against the occupants was that they had harmed the syngeneia by withholding the revenue (phoros), from the produce of these lands which the sanctuary needed to pay for the sacrifices.

An interesting detail of this inscription is that it mentions some of the land in question: in a place called Myrsela, located in, or bordering on, the town of Mylasa. ${ }^{159}$ This demonstrates that not all of the lands belonging to the sanctuary were adjacent or close to each other, nor were they necessarily close to the sanctuary of Sinuri; in fact their position on the edge of the urban center indicates that sacred lands used in this way, i.e. as economic resources rather than for some numinous quality, could hypothetically have been located in any economic zone within the territory of the city. ${ }^{160}$ Another inscription, from Labraunda, mentions the priest Hiereus of Sinuri, probably as the owner of some lands adjacent to those being donated to Zeus Osogollis. ${ }^{161}$ Other places mentioned include Hysarbida, Mosouna, and Xerassos - perhaps villages. ${ }^{162}$ Although we do not know where the syngeneia lived, these inscriptions underscore both the dispersed nature of the lands belonging to Sinuri, as well as

${ }_{15} 6$ I.Sinuri 2, lines 8-9, following the list of the seven names: $[\gamma] \varepsilon v o ́ \mu \varepsilon v o l ~ \tau \alpha \mu i \alpha l \quad x \alpha[i]$

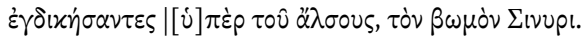

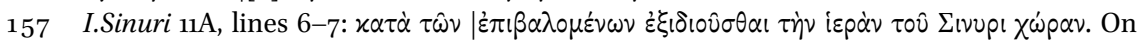
this inscription, see also Dignas (2002a), 100-101, who observes that the low rent rate may have been an incentive for people to rent lands from the gods.

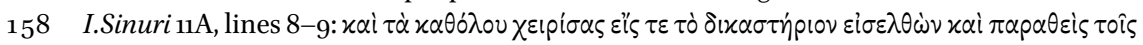

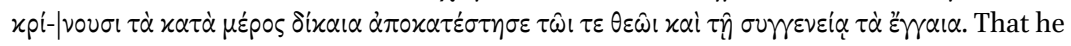
acted with council, or together with other colleague egdikoi, is implied by the use of $\pi \alpha \rho \alpha-$ $\chi \lambda \eta \theta \varepsilon i \varsigma$ in I.Sinuri p. 37 line 13. Robert believes three more inscriptions were dedications to other egdikoi, probably assigned to this same case: I.Sinuri 12, 13, and 14, p. 40-41.

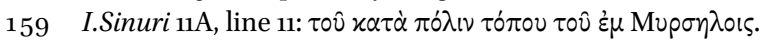

160 On the difference between kinds of sacred landscapes, see Horster (2010).

161 I.Labraunda 8C, line 30, as restored by Piejko (1990), 137 no. 8, following Debord (1969). The lands described were being donated by Olympichos in c. $240 \mathrm{BC}$, and are further

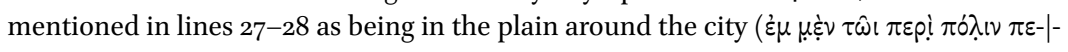
$\delta(\omega)$. Further discussed above, in Chapter 3 on Labraunda, and below.

162 Hysarbida is mentioned in: I.Sinuri $47 \mathrm{a}$, line 7 ; I.Sinuri $48 \mathrm{~b}$, line 5 ; and is restored in I.Sinuri 61, line 2. I.Sinuri $47 \mathrm{~b}$ mentions Mosouna in line 1, and Xerassos in line 9 (as well as a number of references to Hiera Kome). 
their physically close relationship with the polis. The fact that the quantity of contracts in the Hellenistic period rivals that of the Otorkondeis, the largest phyle in Mylasa, indicates a highly prominent position of Sinuri and the Pormounos syngeneia in the rural landscape of Mylasa. ${ }^{163}$

In short, the symbiosis between the cult of Sinuri and its community permeates the epigraphic record at the shrine. A major event in the biography of the sanctuary was surely when the identity of its community shifted from the Pelekos to the Pormounos syngeneia. While the former community enjoyed the favor of the Hekatomnids in the fourth century, the latter, appearing in the third century, was evidently integrated with Mylasa, at least by the second and first centuries BC if not before. The list of priests of Sinuri indicates a fluid transition. The priesthood was for life and probably hereditary, rather than being an elected position. That should hardly surprise, since this was not an urban cult. ${ }^{164}$ Yet by the second and first centuries BC, other religious offices in the cult were elected, the treasurers, the legal representation, those charged with the maintenance of the shrine, and those responsible for managing the sacred lands of Sinuri. In this regard the syngeneia, by now a sub-community of Mylasa, began to mirror itself on the institutions of the polis, even to the extent of using the same calendar and official (and typically Mylasan) jargon in their decrees. Where the syngeneia actually lived is unknown. The Pelekos community may have been more local, but the Pormounos syngeneia appears to have sacred lands scattered across the Mylasan countryside, with at least one tract adjacent to the urban center. This may reflect a dispersed community that met at the festivals of Sinuri. Wherever they may actually have resided, the cult of Sinuri played a central role in physically embedding the community within the landscape of the polis. The syngeneia of Pormounos was heavily engaged

163 This can only be a rough comparison, since all of the Hellenistic decrees found at the sanctuary of Sinuri also derive from there, and probably from the Pormounos syngeneia, while at Mylasa it is much more difficult to identify the origin of the inscriptions when the text is not specific in itself; also the record is much less complete. Nevertheless: 34 inscriptions recording land-lease contracts were found at the sanctuary of Sinuri, I.Sinuri $45^{-72}$ (some of these are sub-divided), only a few pertain to the same property; by contrast, 32 land-lease documents were found altogether at Mylasa, I.Mylasa 201-232. Fifteen of these are identified as belonging to the phyle of the Otorkondeis, most of which concern steps taken in the procurement of three different tracts: that of Iatrokles (I.Mylasa 202-204); Diodotos (I.Mylasa 205-206); and Thraseas (I.Mylasa 207-214); that Zeus Osogollis was also a large landowner is however testified by the inscriptions at Labraunda, I.Labraunda 8 and 69 .

164 Elected priests were the rule for state cults as they were generally less prone to power accrual, e.g. Debord (1982), 62-63 for Asia Minor; for Classical Athens, e.g. Garland (1984) and (1990) and Cole (2008). 
in the land-lease constructions that became so common in the Mylasan area, perhaps due to the volatility of the times and the need for additional, divine security. The meticulous descriptions of the lands inscribed on the walls of the shrine were surely as much a display of pride as an archive of transactions, creating a mental map for the visitor of the world belonging to the Karian god and his community. 165

\section{4 'Urban' Mediatization at the Sanctuary of Sinuri}

The sanctuaries discussed in the other case studies, especially Labraunda, Lagina, and Panamara, became 'urban' sanctuaries in the strict sense of the word - the deities of these sanctuaries came to symbolize the polis and a tight symbiosis developed between city and sanctuary. The sanctuary of Sinuri is different in this regard, since it addresses only a part of the polis, the syngeneia, rather than the entire citizen body. Yet as the previous section has already shown, the Hellenistic syngeneia modeled itself on the polis, adopting some of its institutions and formalities; many of the same processes are thus at work, making this sanctuary a kind of small-scale version of an urban sanctuary. This section explores ways that the sanctuary of Sinuri was used by the syngeneia to engage with the outside world while promoting its own members through the media of honorific decrees and monuments; finally, it briefly discusses the elusive iconography of Sinuri.

\subsubsection{Scope and Network}

Discussions above have already amply emphasized the shift in community at the sanctuary from the Pelekos syngeneia in the fourth century BC to the syngeneia of Pormounos, who appear at least by the third century вС. The Pelekos syngeneia is in fact represented by a single inscription, albeit a critical one, in which they are shown to give heed to a direct command from Idrieus and Ada. ${ }^{166}$ This close relationship between the rulers and the syngeneia reveals a larger role for Sinuri in the conceptual sacred landscape of Karia than implied by the low-profile nature of the shrine's location. Exactly why the Hekatomnids took such an interest in the cult of this Karian god or his syngeneia is not clear. No other cult place has been verified for Sinuri, nor was he syncretized with a Greek counterpart. ${ }^{167}$ There is, however, an inscription from Hyllarima, roughly

165 Horster (2010), 454 on the inscriptions of sacred land documents creating a "virtual and mental religious landscape" in the viewer's mind, discussed further below.

166 I.Sinuri 73, in which Nesaios is admitted into the syngeneia, discussed further below.

167 The relief of the double-axe may indicate some correspondence with Zeus Labraundos, see below. While there is insufficient evidence for the exact nature of the deity Sinuri, various hypotheses as to his origin are addressed in Robert, I.Sinuri p. 12-13 and Laumonier 
$5^{\circ}$ kilometers to the northwest, that describes the location of property being leased as 'in Sinuri, and being of Sinuri'.168 Because of the distance and the fact that the other lands mentioned in the text are much closer to Hyllarima and Stratonikeia, Robert suggests that there was either a place in this area named after Sinuri, or possibly a second sanctuary. ${ }^{169}$ While plausible, the valley southeast of Mylasa appears to have been the locus of his cult, controlled by the syngeneia.

As mentioned above, the transition to the Pormounos syngeneia by the late fourth century seems to have gone smoothly. ${ }^{170}$ At some point in the Hellenistic period, this syngeneia, and thus the sanctuary of Sinuri, was clearly part of the territory of Mylasa. ${ }^{171}$ The question is how intricate the relation between Mylasa and the sanctuary actually was. The words 'polis' and 'Sinuri' are the only legible parts of a heavily fragmented dedication at the sanctuary of Sinuri. This surely implicates the polis of Mylasa as no other polis is known to have been involved with this sanctuary. ${ }^{172}$ Other than this, Mylasa as a polis is not particularly concerned with Sinuri, although another Mylasan syngeneia, the Tarkondareus, appears in a number of inscriptions. ${ }^{173}$ In fact, a member of this syngeneia, Pammenes, son of Hermogeneos, of the Tarkondareus, was even appointed by the Pormounos syngeneia as one of the ktematones to administer the sacred lands. ${ }^{174}$ Syngeneiai were not exclusive and one could belong to different ones at the same time, as discussed above. Possibly this had to do with intermarriage and extended kinship ties. A decree of the Otorkondeis phyle at Mylasa shows the multiple interests of Aristeas Melanos, son of Apollonios: he was one of the ergodotai appointed by the Pormounos syngeneia to manage the sanctuary of Sinuri, but he was also priest of Zeus Hypsistos and Agatha Tyche

(1958), 180-183, who discusses possible Assyrian origins, as well as the names of the syngeneiai.

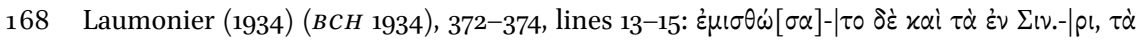

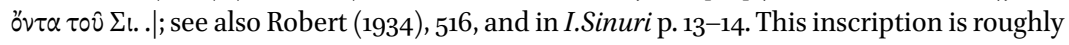
dated to the third century вс.

169 Robert, I.Sinuri p. 13-14; Laumonier (1958), 180-183.

170 The list of priests in I.Sinuri 5 appears to overlaps both syngeneiai, as discussed above.

171 Indicated among others by the dates of inscriptions to the magistrate (stephanephoros) of Mylasa, and the use of its legal infrastructure, discussed further below.

172 As Robert states, "sans doute" regarding I.Sinuri 4, and p. 18-19; dated to the third century вС.

173 E.g. I.Sinuri 14 , lines $3-4$, in an honorific inscription; I.Sinuri 45 is a testament, involving one of the Tarkondareus also named Hiereus ('Priest'), see Robert, I.Sinuri p. 64. The Tarkondareus syngeneia was a subdivision of the Otorkondeis phyle of Mylasa, discussed in Chapter 3.

174 I.Sinuri 47a, lines 2 and 5; a Pammenes, son of Hermogenos is also mentioned in I.Sinuri 5 , a similar but less extensive list of ktematonai. 
in Mylasa, and was furthermore civic magistrate (stephanephoros). ${ }^{175}$ There was thus at least some degree of interaction between other citizens of Mylasa and the syngeneia of Pormounos. Vice-versa, a priest of Sinuri in the later second century, Hybreas of Krateros, is listed as the adoptive father of Hybreas of Polykritos, who was stephanephoros and involved in a Mylasan land-lease transaction. ${ }^{176}$ Finally a statue base in Mylasa is dedicated to Thargylios, son of Aristomenos, 'who became priest of Sinuri', proving that honors could be bestowed within the urban context of Mylasa on someone in this office. ${ }^{177}$

As Robert pointed out, these two priests probably held office after the list of priesthoods had already been inscribed. ${ }^{178}$ Both were in any event part of the urban fabric of Mylasa, more so than we know for the previous hereditary priests. At this point it is unclear exactly how they came by their priesthood, what their affiliation with the Pormounos syngeneia was, or whether the syngeneia was still active by the first century or whenever the statue for Thargylios was erected. ${ }^{179}$ In any event, by the end of the first century вС little more is heard from the syngeneia of Pormounos, their sanctuary, or of Sinuri. The only evidence we have of further activity are the two tombs from the Roman period, just north of the temenos, as well as a few bronze coins from Stratonikeia from the Severan period, but these were common in the area, given the regional dominance of the polis to the east in this period. ${ }^{180}$ Yet a continued awareness of the shrine may be seen in the Byzantine period with the erection of a basilica on top of the ancient place of cult.

In summary, the scope of the sanctuary of Sinuri was restricted to the level of syngeneia, although the affiliations of this body changed. In the Late Classical period the Pelekos syngeneia was apparently significant enough to draw the attention of the Hekatomnid rulers to this remote sanctuary, yet remained autonomous. After their passing, the shrine fell to the Pormounos syngeneia who, although a sub-community of Mylasa, administered the shrine via an

175 Aristeas, son of Melas, son of Apollonios appears in I.Sinuri 9, lines 24-26 as one of the ergodotai of the Pormounos sygneneia, and is stephanephoros of the polis in I.Mylasa 212, line 2, where he is still listed as priest of Zeus Hypsistos and Agatha Tyche; see Robert, I.Sinuri p. 30-31, here he further identifies two of the stephanephoroi mentioned in the Sinuri inscriptions as being active in Mylasa: Leon, son of Theomnestos, in I.Sinuri 9, and Hermios, son of Polites, in I.Sinuri 46.

176 Blümel (1989), 12-13, no. 103, line 2; I.Mylasa 217, lines 6-7 (Blümel et al. (2014) no. 2\&3).

177 I.Mylasa 763 dated to the mid-first century вс.

178 Robert, I.Sinuri p. 25.

179 See above; Robert postulates that the priesthood may have been elected by the Mylasans, rather than the syngeneia, or it may have been put up for sale as with others, see above and Robert I.Sinuri 25.

180 Robert, I.Sinuri p. 29. 
institutional model inspired by the polis. The sanctuary of Sinuri was an urban microcosm, reflecting the organizational format of the polis in a scaled down version of a regular urban sanctuary, expressing and reinforcing the essential identity of the community involved with it; this will become more apparent in the next section.

\subsubsection{Civic Decrees within the Syngeneia}

The sanctuary of Sinuri was a podium for the syngeneiai who were involved with it. As with polis sanctuaries, decrees here were also issued that concerned the constitution of the community, and by this mechanism new members were admitted while others were honored for their positive contribution to the community and the sanctuary.

In fact, the only inscription securely connected to the Pelekos syngeneia, I.Sinuri 73 , shows them honoring an individual named Nesaios, among others, by admitting him into the syngeneia as their 'brother' and granting him personal exemption (ateleia) from public dues, except for the divine, or royal, revenues, followed by a curse on anyone who violates this decree. ${ }^{181}$ Nesaios also appears in the heavily fragmented inscription I.Sinuri 74, in combination with the festival of the Syennia - possibly the festival in which he was admitted to the syngeneia. ${ }^{182}$ The privilege and the praise bestowed upon Nesaios reveals his special status; as discussed above, he evidently brought with him a personal mandate from Idrieus and Ada, the Hekatomnid rulers of Karia after Maussollos's death. 183

The Pormounos syngeneia used the sanctuary in a very similar, communal way. One of the earliest attestations of their presence is I.Sinuri 44 (Figure 4.25),

181 I.Sinuri 73, line 7: $\dot{\alpha} \delta \varepsilon \lambda \varphi \dot{\partial} v \dot{\varepsilon} \alpha \nu \tau \hat{\omega} v$, Robert sees this as an indication of the fraternitylike character of the syngeneia, see p. 96, also discussed above. Lines 11-12 are revised in Robert (1949), based on Wilhelm (1947), 16-20 - this section now reads $\varphi[$ [ó $\rho \omega[$ [v?] $\mid[\pi \dot{\alpha} \nu] \tau \omega \nu \dot{\alpha} \tau \dot{\varepsilon} \lambda \varepsilon\left\llcorner\alpha \nu \pi \lambda \dot{\eta} \nu \dot{\alpha} \pi \circ \mu\left[0 i p \alpha \varsigma^{\cdot}\right]\right.$. Hornblower discusses the early appearance of apomoira as an Achaemenid tax form, later adopted by the Ptolemies, Hornblower (1982), 72 and 162. A close parallel with I.Sinuri 73 may be seen at Labraunda in the third century, when the Korris syngeneia is shown honoring two individuals in I.Labraunda 11 and 12, see above.

182 I.Sinuri 74, line 4: .ГINH $\Sigma$ AIOY, and line 6: . $\Sigma \Sigma$ YENNIOI $\Sigma$. Adiego has shown that this inscription is the latter section of I.Sinuri 75, both of which are bilingual; Adiego (2000), 133-139. The dedication fragment I.Sinuri 3 , from the fourth century BC probably refers

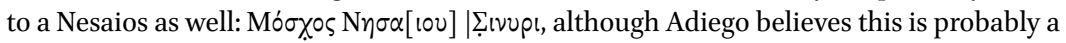
different person, Adiego (2000), 136.

183 Hornblower discusses the possibility of Nesaios as a satrapal agent of the Hekatomnids, who may have ordered the Pelekos to admit him into the syngeneia, Hornblower 1982, 72-73. 
an inscription from the late fourth or early third century which admits a certain Samiades, son of Theodotos, into the syngeneia, allowing him and his descendants the right to share in everything belonging to the syngeneia. ${ }^{184}$ Obviously the constitution of the syngeneia was a critical matter and the sanctuary was the most appropriate place to record such significant changes; being accepted as a member was a religious act that allowed access to the resources of this community, to all things sacred and common, including participation in the festivals at the sanctuary. Inscribing this decision at the sanctuary ensured the recognition of this basic right within the community for generations to come.

The later decrees of the Pormounos syngeneia reveal a strong similarity with the political language of the polis, showing in particular how they modeled themselves on this major institution. Legality was especially a major concern. As with any legal document in the urban sphere, they began with an annual date in a widely recognizable format, i.e. based on the stephanephoros of Mylasa that year, and the month (and sometimes days) in which the decree was issued. ${ }^{185}$ The honorific decree for Dionysios, son of Leon of Kosetios, discussed above, gives a good example of this. ${ }^{186}$ After the date is established, the inscription continues with the subject of the decree, and then in line 2 the decision itself is prefaced with, it was determined by the Pormounos syngeneia .....187 The decision-taking body, i.e. the syngeneia, is now depicted as a homogenous entity, much like the boule and demos of the civic decrees. As discussed above, this is in contrast with the older formula, like that in I.Sinuri 44 just discussed, in which the decisions were taken by the entire koinon of Pormounos syngeneia, or by the Pelekos syngeneia who all assembled together. ${ }^{188}$ The next phrase is typical of the Hellenistic decrees of the Pormounos syngeneia, stating that so-and-so 'introduced and declared the motion'. This particular formula, gnomen apophenamenou, is peculiar to the Mylasa area, and is used almost exclusively by the Otorkondeis phyle, but also by the demos of Olymos, which was absorbed by Mylasa. ${ }^{189}$ The fact that

184 I.Sinuri 44, p. 56-62 on the date of this inscription and the possible identities of the eponymous Pleistarchos.

185 As stated above, the Hellenistic decrees at the sanctuary of Sinuri followed the same calendar as Mylasa, see Robert, I.Sinuri p. 30-31.

186 I.Sinuri 11.

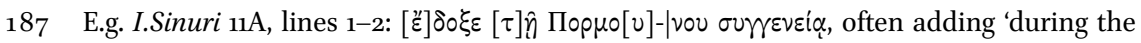

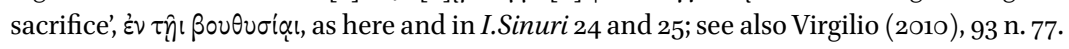

188 See Robert, I.Sinuri p. 55 and 95, discussed above.

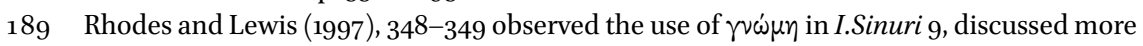

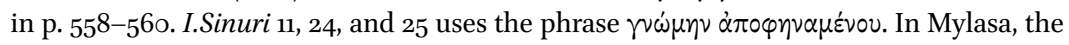
same phrase in singular or plural appears in the decrees of the phyle of the Otorkondeis: I.Mylasa 109, 110, 111, 114, 157, 203, 207, and 231; and of the phyle of the Hyarbesytai: I.Mylasa 
TABLE 4.1 Hellenistic inscriptions at Labraunda (37 total) and Sinuri (84 total)

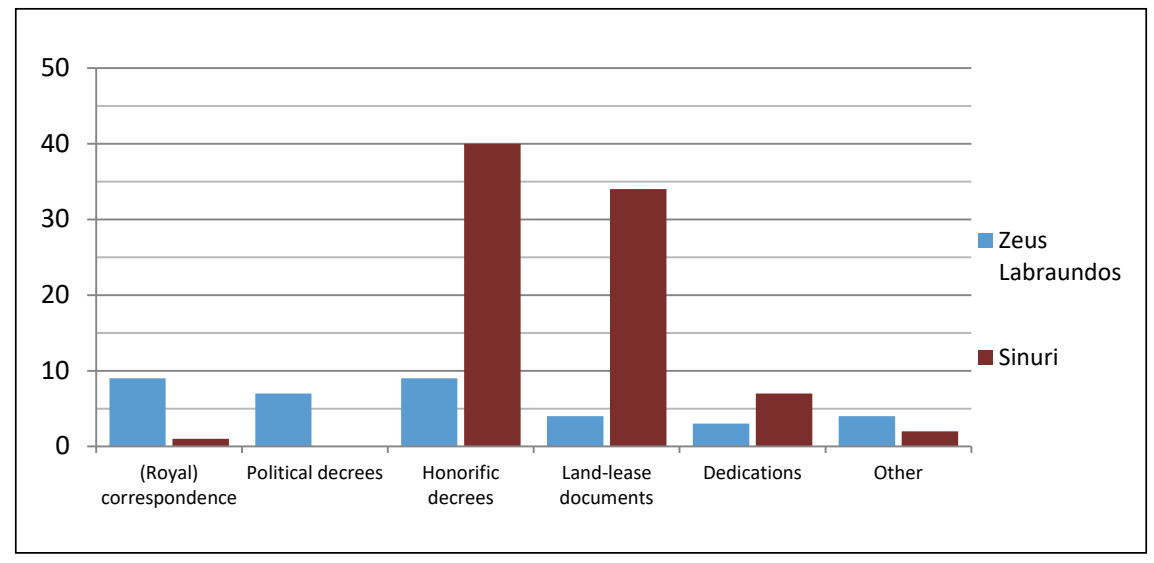

Breakdown according to type: royal, political, honorific, land-lease, dedications, other

the Pormounos syngeneia use this same formula in their own meetings demonstrates the extent of their integration in the political culture of the polis, and proves that they were not an isolated community who simply co-existed alongside the greater city. In fact, their institutionalism and way of operations indicates that they consciously adopted the organizational style of the polis. 190

Honorific decrees further make up over half of the inscriptions from the Hellenistic period found at the sanctuary of Sinuri - four times as many of this type were discovered here as at Labraunda (Table 4.1). Even allowing for the many fragments and the probability that not all of the inscriptions have yet been recovered at either sanctuary, these proportions are nonetheless highly significant, especially when taking into consideration the fact that the sanctuary of Sinuri represented only a part of the population of Mylasa, whereas the entire polis participated in the festivals at Labraunda.

The high number of honorific decrees indicates that this sanctuary was perhaps even more of an 'urban platform' than Labraunda, at least for honoring people for the ways in which they benefitted the community. In this sense it surely was the nexus of the popular identity of the Pormounos syngeneia, a

301. It also appears by the demos of Hydai, I.Mylasa 902.1, and of Olymos: I.Mylasa 8o1, $802,819,829,861$, and $E A 13,1989,7-8$, no. 895. The formula seems to be unique to the

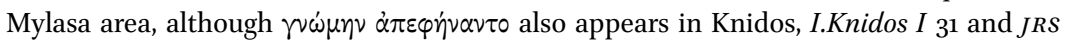
$64,1974,195^{-220}$.

190 For an in-depth discussion of 'political culture' and its permeation throughout the Hellenistic world, see van Nijf and Alston (2011). 
trend that was more widely apparent throughout the various Mylasan communities, as discussed in the concluding section of this chapter.

Taken together then, these inscriptions show an important shift in the image of the Karian syngeneia. In the Late Classical period they were largely autonomous political units, as Robert observed. ${ }^{191}$ The relationship between the Pelekos syngeneia and the Hekatomnids exemplifies how sanctuaries could be used by such independent local communities to negotiate their position with the wider ruling powers. By the Hellenistic period, however, syngeneiai had generally become nested within the structure of the nearest, or most dominant, polis. The inscriptions of the Pormounos syngeneia indicate that at least some syngeneiai were able to maintain a balance between their identity as a group and their role as a subsidiary of the polis, by using the sanctuary as their own platform.

\subsubsection{Cult Iconography}

About the god Sinuri himself, we know very little other than that he retained his indigenous name rather than being assimilated with a Greek god (for example Zeus), and that he had no female counterpart. ${ }^{192}$ Two terracottas found at the sanctuary, however, may indicate some connection with Aphrodite, ${ }^{193}$ while the sculpted Dioskouroi cap establishes a connection with the worship of the twin gods, as discussed above. ${ }^{194}$

Perhaps the most interesting find however is the double-axe sculpted in relief on a block of red marble. ${ }^{195}$ This is interpreted by Robert as an attribute of Sinuri, yet given the appearance of the double-axe elsewhere, for example at the sanctuary of Hekate at Lagina where it was certainly not an attribute of the

191 Robert, I.Sinuri p. 93: "La syngeneia, avant d'être dans les cites hellénisées une subdivision de la tribu, a dû être une cellule indépendente de la vie politique dans les campagnes de la Carie."

192 In contrast with Zeus Panamaros, who is generally believed to have been a local Karian god that was later assimilated, e.g. Laumonier (1958), 339-340; Hanslik-Andrée in $R E$ s.v. 'Panamaros': "eines dem Zeus angeglichenen altkarischen, spatter graezisierten Himmelsgottes." Hera was added to the cult once the sanctuary was locked into the orbit of Stratonikeia, see below in Chapter 6 .

193 Devambez (1959), 30-31, Pl. XXVIII. The terracottas include a head of Aphrodite, a relief of Eros (perhaps from a vase); part of a terracotta lion's head was also found, probably Roman.

194 Discussed above in connection with I.Sinuri 8, the dedication by the priest Menippos to the savior gods; see also Robert I.Sinuri, p. 22. The cap-shaped stone is shown on Pl. vilI.

195 Robert in I.Sinuri p. 14 and Pl. viII; the relief is not dated. 
goddess, ${ }^{196}$ it may well have simply been deployed as a wider Karian symbol, or as a direct allusion to Zeus Labraundos. In this case, using this emblem would have been a way of establishing a link between the powerful god of Karia and this local deity, while reinforcing the more regional identity of the syngeneia. Whether the relief was created under the administration of the Pelekos or the Pormounos syngeneia is unknown, but it is tempting to connect it with the name Pelekos, if this was in fact a derivative of the word $\pi \dot{\varepsilon} \lambda \varepsilon x \cup \varsigma$, or (double) axe. ${ }^{197}$ Both the relief and the name of the syngeneia (and priest) probably took their inspiration from the same primal Karian source.

To summarize, the sanctuary of Sinuri was thus always focused on the syngeneia, but the structure of this body underwent an important transition. In the Late Classical period, the Pelekos syngeneia appears to have largely been an autonomous political entity, answering directly to the ruling dynasty. In the Hellenistic period, however, the new syngeneia of Pormounos clearly operated under the umbrella of the polis and had some degree of interaction with it. ${ }^{198}$ Both syngeneiai held the sanctuary of Sinuri as their central place. This was where they met to discuss matters of importance, issue decrees, admit members, and ultimately to define and celebrate themselves through their festivals for Sinuri. This local level of governance seems to have remained the norm throughout the life of the sanctuary. Most of the honorific decrees found there were issued by phylai or syngeneiai, rather than by the institutions of the polis. The vociferous syngeneia of Pormounos further maintained its multifarious identity through the rituals of Sinuri. In the first place, it profiled itself as a local festive but also administrative body, focused on maintaining the cult of Sinuri. In the second place, it was clearly affiliated with Mylasa and adhered to its institutions, as demonstrated above. Finally, the double-axe relief, at least as emblem, indicates the syngeneia's regional awareness of its Karian identity. Although it concerned only a part of the urban population, this community used the sanctuary in much the same way that urban sanctuaries were used by a polis: as a public space for the community; as a place for ritual performance that strengthened social cohesion; as a source of divine but also economic

\footnotetext{
196 At Lagina two small stones or altars bearing a double-axe were found, and the double-axe appears in a number of the coffers from the ceiling of the temple, constructed in the later second century BC; see below in Chapter 5 .

197 Laumonier discusses the name and spelling of the priest Pellekos and the syngeneia Pelekos, in Laumonier (1958), 182-183; he further suggests that Pelekos could have been the original name of the god with the hatchet. The more common word is $\lambda \dot{\alpha} \beta \rho \nu \varsigma$, a possible source for the name Labraunda.

198 Robert, I.Sinuri p. 93, quoted above in note 122.
} 
security through the sacred domains; and finally, as mediator of identities individual, communal (or tribal), urban (or political), and regional.

\section{Interpreting Change in the Relationship between Mylasa, the Sanctuary of Sinuri and the Syngeneiai}

The preceding section has made it clear that the availability of sources, besides their content, will already partly determine the ways in which we can interpret the connection between the sanctuary of Sinuri and its community. Without knowing where the syngeneia of Pormounos lived, or whether processions were even part of their rituals, we can but speculate as to how the sanctuary was spatially integrated with the community. Also the upheaval of the monumental structures by the Byzantine reconstruction of the ancient sanctuary has heavily clouded our understanding of the exact layout of ritual space in earlier times.

Despite these impediments, we have nonetheless been able to ascertain several important aspects that may be used as a base for modeling the relationship between this remote cult place and the wider community of the polis. The monumentality of the temenos walls, as part of the Hekatomnid program, already points to this sanctuary in the isolated valley as an important place in the sacred landscape of Karia. Functions that particularly stand out here, more so than at any of the other sanctuaries discussed in this volume, are the strong emphasis on the sacrificial ritual itself, the finely tuned management of the sanctuary and its holdings as well as the high number of honorific decrees, and the relatively large number of land-lease documents.

The sacrificial ritual is of course the main event of ancient Greek festivals, but in the festivals of Sinuri this was stressed even more than usual - inscriptions show that the entire festival is typically designated as 'the oxen-sacrifice' (bouthysia) and the ritual itself was the defining event for the community. The architecture underscores this as well. While the area was enlarged by the Hekatomnids, the way that it was further articulated by the Pormounos syngeneia, enclosed on the eastern side by a stoa, created a kind of concentric space in front of the altar, thus spatially highlighting the sacrifice as the climactic ritual event for the community. Although the exact shape of this concentric space may not be clear, its place before the altar nonetheless shows that it would have functioned like an 'inward-facing circle', allowing for the ideal transfer of community knowledge. ${ }^{199}$ Inscriptions show that the sacrifice

199 Chwe (2001), 30-33. 
to Sinuri was in fact the moment in which the syngeneia took decisions that affected the community and honored its members for their affirmative actions, year after year. Embedding these decrees and commemorations within the sacrificial performance not only created a religious (and permanent) context for them, but proved public ritual to be the ideal medium for transmitting such knowledge and creating collective memories. ${ }^{200}$ The repetitive nature of the ritual works as a mnemonic device, much like a commercial jingle; communicating decisions and honoring members during this ceremony simply inserted this knowledge into the flow of ritual performance, thus ensuring its place within the collective memory. ${ }^{201}$ The nature of the sacrifice and the space in which it was performed both underscore the importance of social cohesion to this community, and show how the festivals for Sinuri functioned as rational rituals, at least in the Hellenistic period.

The Pormounos syngeneia clearly operated under the aegis of Mylasa, although we cannot state with any certainty whether they lived in town, on the fields, or near the sanctuary. Yet their 'home' was clearly the sanctuary of Sinuri - this was their administrative center, this was the place they held in common and which brought them together every year; this was the center of their identity. Their intricate management of the sanctuary and its lands, but especially their honorific decrees, together demonstrate how they maintained their own communal identity while adopting the practices and institutions of the polis.

On the one hand, the sanctuary of Sinuri presents a picture of an older indigenous cult place that continued to operate in much the same fashion as it always had, prior to the advent of the polis model. Such sanctuaries were the religious, social, economic and administrative centers of a local community, and were typified by a hereditary priesthood, and a degree of economic selfsufficiency, usually based on their sacred domains. ${ }^{202}$ Yet on the other, rather

200 Chwe (2001), 11-16, 25-30 on public ritual as a means of common knowledge. On ritual and the cognitive apparatus in general, see McCauley and Lawson (2002), discussed above in Chapter 2.

201 Ritual is an excellent mnemonic device, and a way of consolidating collective memories, e.g. McCauley and Lawson (2007); Connerton (1989), 49-61. This is discussed in more detail above in Chapter 2.

202 Most of Boffo's categories concerning indigenous sanctuaries in Asia Minor view them as the hearts of communities, Boffo (1985), discussed above in Chapter 2; see also Marchese (1989). This structure is similar to federation or koinon sanctuaries (e.g. Panamara discussed below in Chapter 6), or also the ethnoi in Archaic Greece, e.g. Morgan (2003), 107163. On the sacred lands, e.g. Dignas (2000), but also Horster (2004), 143-191, who studying Archaic and Classical Greece, states that most of the leased lands from these sanctuaries would not have paid for much more than the sacrifices. 
than being an anachronism, the sanctuary of Sinuri was in all likelihood representative of the way in which most Mylasans continued to express their popular identity while formally being part of the larger organization of the polis. The municipal subdivisions, the phyle and the syngeneia, that appear to have been the main channels for the social identity of the people, is demonstrated particularly through the number of honorific decrees issued by these bodies at their own local sanctuaries. ${ }^{203}$ Nearly half of the 57 honorific decrees discovered in the urban area of Mylasa were dedications made by the phylai and syngeneia, twice as many as the boule and demos issued (Table 4.2). Adding the 40 honorific decrees by the Pormounos syngeneia alone significantly increases this proportion, and, while these figures cannot immediately be taken at face value (since the sanctuary of Sinuri has been excavated whereas ancient Mylasa is still largely covered by modern Milas), they are nonetheless indicative of the wider trend of honoring individuals within more familiar and intimate circles, rather than at the civic level. ${ }^{204}$ The operations of the Pormounos syngeneia were surely similar to that of their predecessors, the Pelekos syngeneia. The main difference would be that the members of the Pormounos syngeneia were not only incorporated within the sphere of the polis, they also knew their way around its infrastructure and made rational use of its institutions to their own advantage.

This is not the place to go into the Mylasan decrees in any great detail, but the boule and demos were principally concerned with the political and external identity of the polis, and this is what was expressed in the decrees at Labraunda (e.g. Table 4.1, but also at the urban sanctuary of Zeus Osogollis, the other main deity of Mylasa). The popular identity of the Mylasans themselves, however, was still rooted in the 'local' level - perhaps reflective of the ongoing

203 E.g. the phylai of the Otorkondeis at Zeus Otorkondeon, (I.Mylasa 106, 113, 115, 156, 157, 204, 207b, 208, 209, 211, 214, and 216) or Zeus Osogollis (I.Mylasa 110, 112), and the Hyarbesytai with Zeus Hyarbesyton (I.Mylasa 301); the syngeneiai of the Aganiteis at their sanctuary of Zeus Aganiteon (I.Mylasa 121) and of the Maunnites with Zeus Maunniton (I.Mylasa 154).

204 This table is based on the honorific decrees listed in I.Mylasa, nos. 101-157; any conclusions are preliminary of course, given the size of the category 'unknown', and the fact that Mylasa has not been systematically excavated. Another example, however, is the number of cases in which individuals were crowned. The demos of Mylasa crowns individuals 6 times, in: I.Mylasa 101, 128, 148, 632, 634, and at Labraunda in I.Labraunda 48; the Korrides syngeneia also issued a crown at Labraunda, I.Labraunda 11. Individuals in Mylasa were twice as likely to receive a crown from one of the phyle, e.g. the Otorkondeis in I.Mylasa $105,106,108,110,112,113,114$, and 157; or the Konodorkondeis in I.Mylasa 119, 120; or an unknown phyle in I.Mylasa 136 and 140. The Pormounos syngeneia gave out 7 golden crowns in I.Sinuri 11, 16, 18, 20-22, and 37, discussed above. 
TABLE 4.2 Breakdown of the Hellenistic honorific decrees found at Mylasa according to issuing body

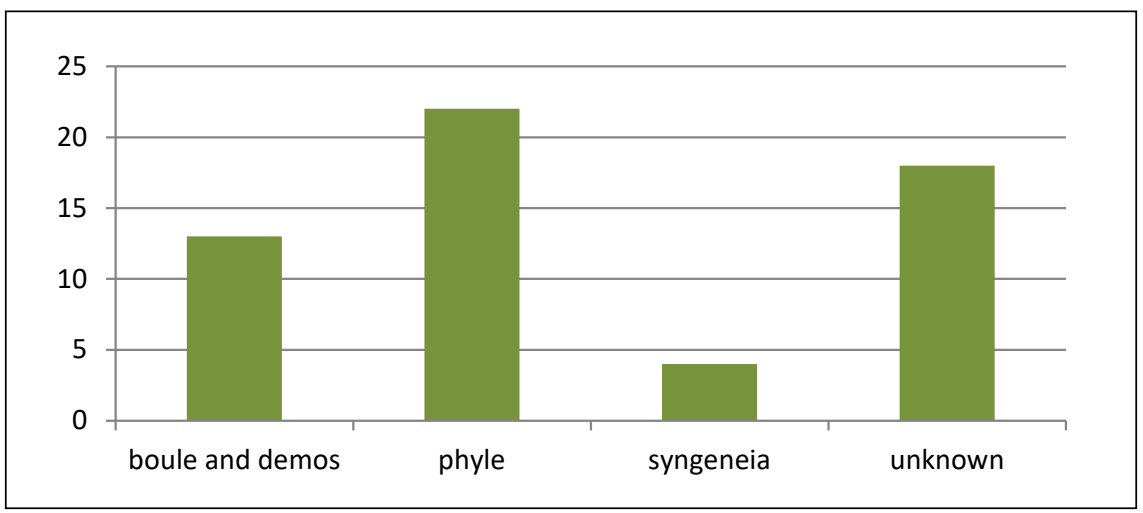

Total of 57 inscriptions, of which 39 were identifiable. Of the phylai: 15 were issued by the Otorkondeis, 2 by the Konodorkondeis, and 5 were unidentified. Of the syngeneiai: 2 were issued by the Aganiteis, and 2 by the Ogondeis

life of the communities that made up the town through the synoikism of the fourth century вС. ${ }^{205}$

Regarding the urban identity of Mylasa, in this context, one then needs to take into account the persisting diverse origins of its social composition. Through this scope it is immediately clear why the polis had such an animated sacred landscape: in the Hellenistic period Mylasa comes across as a multifarious institution, institutionally based on the Greek model of the polis yet still rooted in the local Karian communities that had been drawn together to make up the actual town. In this sense, the religions of the polis work in exactly the opposite direction of what Sourvinou-Inwood observed for the Classical period at Athens. ${ }^{206}$ It is the local communities who structure their own world and identity, the polis of Mylasa seems to have been an abstract collection of these; witness for example the many different cults for Zeus just in Mylasa alone. They were not all celebrating a central polis cult within the context of their local festivals, but their own identity instead. ${ }^{207}$

205 For the synoikism of Mylasa, see Radt (1969/7o), 168-169 n. 17; Rumscheid (2010), 97-98.

206 Sourvinou-Inwood (1990), 302: "The polis was the institutional authority that structured the universe and the divine world in a religious system, articulated a pantheon with certain particular configurations of divine personalities, and established a system of cults, particular rituals and sanctuaries, and a sacred calendar."

207 Hence the opposite of what Sourvinou-Inwood observes for Classical Athens, Sourvinou-Inwood (199o), 312-313; also Roussel (1976), 207 n. 38, 216. 
While the honorific inscriptions show the Pormounos syngeneia to be a microcosm of the structure of Mylasan society, their many land-lease inscriptions testify to the physical integration of the sanctuary and the syngeneia in the wider territory of Mylasa. By the late third century вс these lands had already become lucrative holdings, demonstrated by their attraction to Antiochos III's troops. Assuming that Virgilio's restoration is correct, the letter posted by Antiochos III furthermore shows that persons belonging to the sanctuary were actually living on these lands in and around Mylasa, since they had been taken hostage during the pillaging. ${ }^{208}$ Several of the land-lease transaction documents date from after this violent period; their detailed descriptions paint a picture of the lands belonging to Sinuri as being scattered throughout the countryside, from Hiera Kome near the sanctuary up to the edges of the town center. Based on the relatively large quantity of these transactions, a good portion of the landscape surrounding Mylasa seems to have been transferred to Sinuri under the administration of the Pormounos syngeneia. Inscriptions testify to the great concern of the Pormounos syngeneia with the proper administration of these holdings, even going to court in Mylasa when they were misused. These lands formed of course the economic backbone of the sanctuary of Sinuri and of its festivals, ${ }^{209}$ but probably also a major part of the resources of the Pormounos syngeneia itself. Although we are ignorant of a sacred way that could link the various economic zones together en route towards the sanctuary, the knowledge of the extensive holdings of the god provides nonetheless a different kind of indication of how the landscape around Mylasa was physically bound to the sanctuary of Sinuri. Besides economic, this connection was also legal, and the transactions were inscribed as juridical documents; no doubt some of these were actually copied and used as evidence in the Mylasan court during the legal defense by the syngeneia against the illicit appropriation of some of the domains. ${ }^{210}$

The inscriptions however go one step further. Besides their function as legal documents, their public locations and fact that they could be read by future generations projected a mental image of the vast estates of the god upon the visitor, just as it does with us. Marietta Horster pointed out that the often overwhelmingly long lists inscribed on the walls of sanctuaries with sacred lands could work to create a kind of "virtual and mental religious landscape" in the

208 Virgilio (2010), 8o-88 on the 'snatched sacred bodies' discussed above.

209 On the economics of sacred lands, Debord (1982), 127-180, Part 3 'Les dieux et la terre', esp. 168-169; Bringmann and Noeske (2000), 97-107; Dignas (2000); Chandezon (1998) and (2003) esp. 240-248; this is also discussed above.

210 I.Sinuri 11, discussed below. 
mind's eye. ${ }^{211}$ Even if the documents were inscribed in different places in the sanctuary, they would have created an overall impression of the great wealth of the god all around the countryside of Mylasa. This, together with the publicity from the trial, the pillaging by Antiochos III's troops, and probably the memory of the patronage by the Hekatomnids would have all worked together to make sure that the sanctuary of Sinuri was a bright dot on the mental maps of the Mylasans, whether or not it was actually part of the routine their daily lives.

Just looking at the map, one might interpret the second bloom of the sanctuary, and its investment in property, in light of border disputes between Mylasa and Stratonikeia, the rising city farther east which, like Mylasa, also began to expand especially in the second half of the second century вс. ${ }^{212}$ The sanctuary of Sinuri is located roughly midway to Stratonikeia, near what must have been the eastern perimeter of the territory of Mylasa. Yet if it were a 'true' frontier sanctuary, then one would expect it to have had a much more prominent place in the physical and mental topography of the Mylasans. Instead it appears to be almost hidden in a largely isolated valley, of primary interest only to the Pormounos syngeneia, rather than the population as a whole. The picture that emerges is a curious contrast with Labraunda. Although the sanctuary of Sinuri belonged to the sacred landscape of Mylasa, the polis did not seem to be particularly involved in the cult, e.g. through processional routes which implicitly or explicitly claim the surrounding countryside, or overt displays of urban pride or polis rivalry. ${ }^{213}$ The sanctuary of Sinuri was neither a frontier sanctuary, nor does it seem to have played any kind of pivotal role in the political power of landscape, as did the sanctuary of Zeus Labraundos. ${ }^{214}$ The shrine at the far end of this secondary valley was instead relegated to a subdivision, the syngeneia, who used it as podium for their own performances of 'urban rituals'.

The sanctuary of Sinuri is one of the best examples of the way in which ritual gave focus to a community. At the same time, it shows how the institutions and administrative practices of the polis were adopted and applied at a

211 Horster (2010), 454: "Thus, in the reader's, or viewer's mind - if he was not able to read the long texts with tiny letters - the documentation of the leases of sacred land might have generated a virtual and mental religious landscape including the vision of large estates of landed property of the respective deity."

212 E.g. I.Mylasa 134 concerns a boundary dispute between Stratonikeia and apparently one of the phylai of Mylasa; see also Ager (1996), no. 101. Stratonikeia and its sanctuaries are discussed in detail in Chapters 5 and 6.

213 E.g. de Polignac (1995); Graf (1996); Chaniotis (1995); discussed above in Chapter 2.

214 Or Meter Theon at Mamurt Kale, the highest peak in the vicinity of Pergamon, Williamson (2014a). 
smaller scale. The festivals of Sinuri gave the syngeneis a vehicle for balancing the overlapping layers of their nested identities: individual (through tasks, offices, and public honors); collective (as syngeneia); urban (through adhering to the legal and institutional forms of Mylasa, but also as landowners of a good deal of property in the territory); and even regional (the Karian double-axe, the legacy of the Hekatomnids). In this sense, it acted as an urban sanctuary, albeit one that was targeted to a subsection of the population. 